WSRC-TR-92-42-011

ENGINEERING EVAIOATION OF THE GENERAL MOTORS (GM)

DIESEI RATING AND CAPABILITIRS (J)

BY: Robert E. Gross

April 1992

WESTINGHOUSE SAVANAAH RIVER COMPANY
SAVANNAB RIVER SITE
AIKEN, SOUTE CAROIINA 29808 
This report was prepared by Westinghouse Savannah River Company (WSRC) for the United States Department of Energy under Contract No. DE-ACO9-88SR18035 and is an account of work performed under that contract. Neither the United States Department of Energy, nox WSRC, nor any of their employees makes any warranty, expressed or implied, or assumes any legal liability of responsiblilty for the accuracy, completeness, or usefulness, of any information, apparatus, or product or process disclosed herein or represents that its use will not infringe privately owned rights. Reference herein to any specific commercial product, process, or service by trademark, name, manufacturer or otherwise does not necessarily constitute ox imply endorsement, recomendation, or favoring of same by WSRC or by the United states Government or any agency thereof. The views and opinions of the authors expressed herein do not necessarily state or reflect those of the United States Government or any agency thereof. 


$$
\begin{array}{ll}
\text { Received by OSTI } & \text { wSRC-TR--92-42-011 } \\
\text { AUB } 201992 & \text { DE92 } 019933
\end{array}
$$

\title{
ENGINEERING EVALUATION OF THE GENERAL MOTORS (GM) DIESEL RATING AND CAPABILITIES (U)
}

by

\author{
R. E. Gross
}

Westinghouse Savannah River Company

Savannah River Site

Aiken, South Carolina 29808

A technical deliverable being deposited at OSTI

This report was prepared in connection with work done under Contract No. DE-AC09-89SR18035 with the U.S. Department of Energy. By acceptance of this report, the publisher and/or recipient acknowledges the U.S. Government's right to retain a nonexclusive, royalty-free license in and to any copyright covering this report, along with the right to reproduce and to authorize others to reproduce all or part of the copyrighted report. 
WSRC-TR-92-42-011

ENGINEERING EVALDATION OF TAE GENERAI MOTORS (GM)

DIESEI RATING AND CAPABIIITIES (O)

BY: Robert E. Gross

April 1992

WESTINGHOUSE SAVANNAB RIVER COMPANY
SAVANNAB RIVER SITE
AIKEN, SOUTH CAROIINA 29808 


\section{TABIE OF CONTENTS}

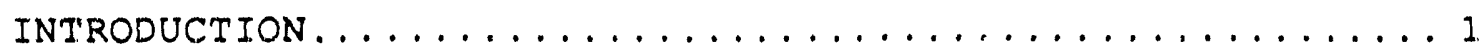

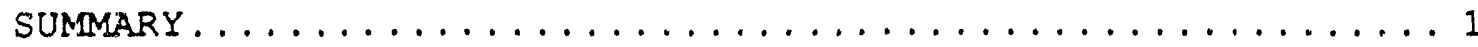

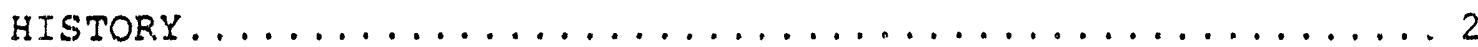

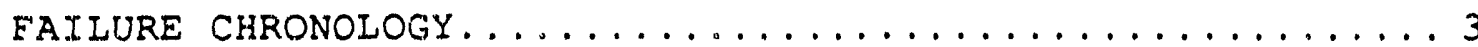

K-Reactor Engine Disassembly-Sept/Oct $1990 \ldots \ldots \ldots \ldots 3$

K-Reactor Engine Assembly-Nov 1990 thru Jan $1991 \ldots .4$

K-Reactor Engine Disassembly-Feb $1991 \ldots \ldots \ldots \ldots$

GM Diesel Task Team Created..................

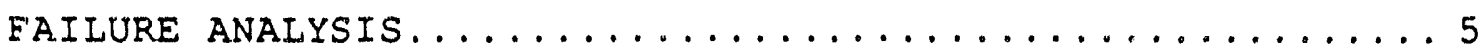

Failure Analysis Associates (FaAA) ............

Engineered Applications Corp (EAC) ............

Trident Engineering Associates, Inc (TEA).........6

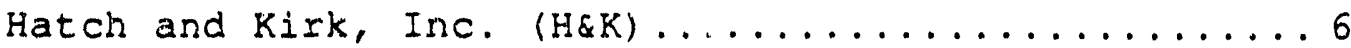

$E, C$ AND I-REACTOR ENGINE DISASSEMBLY............6

General. . . . . . . . . . . . . . . . . . . . . . 6

Surface Finish Measurements.................

P-Area ..............................

C-Area............................

L-Area.........................8

FINAL K-REACTOR GM ENGINE ASSEMBLY.............. 9

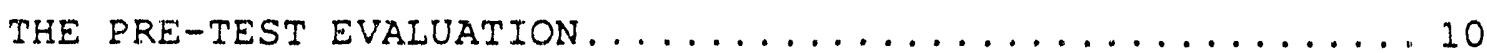

US Navy historical data and technical documents..... 10 Cleveland design/factory testing data...........11 Review of root cause failure analysis/discussion

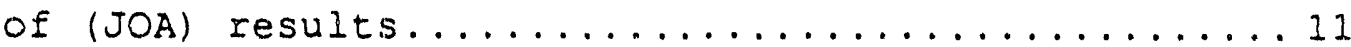

Proposal for break-in testing schedules.........11

Development of critical performance indicators.....12

Independent consultant statements of support........14

TEST RESULTS........................... I4

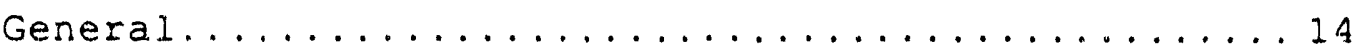

Data Acquisition....................... 5

Engine Parameters........................ 15

Firing pressures.......................

Exhaust Temperatures...................16 


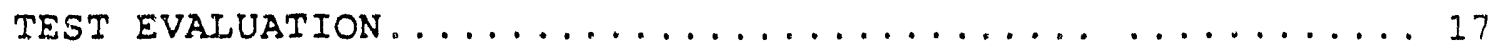

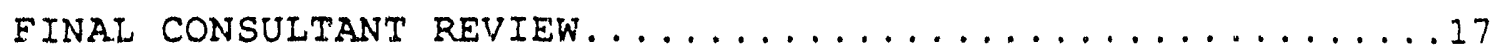

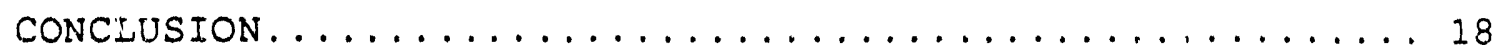

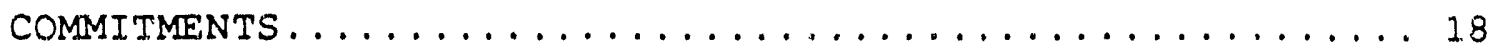

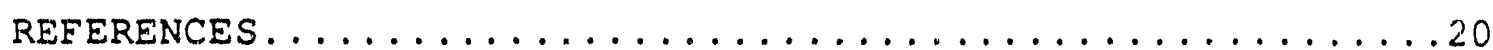

\section{IIST QF TABIES}

TABLE 1

WRIST PIN GEOMETRIC CHARACTERIZATION

TABLE 2

COMPARISON OF GM CLEVELAND MODEL 16-2768A VARIOUS RATINGS \& DESIGN PARAMETERS

TABLE 3

GM D/G DATA COLIECTION

\section{IIST OE EIGURES}

FIGURE IA

MODEI 278A DIESEL ENGINE - BLOWER END AND SIDE VIEW

FIGURE 1B

CROSS SECTION OF MODEL 278A ENGINE

FIGURE 2A

GM-1K COMPRESSION READING JULY 1990 TO FEBRUARY 1991

FIGURE 2B

MODEL 278A DIESEL ENGINE POWER CYCLE

FIGURE 3

GM \#1K CYLINDER COMPRESSION DIFFERENCE FROM AVERAGE

FIGURE 4

ILLUSTRATION OF EXCESS CLEARANCE DUE TO PISTON PIN BUSHING WEAR

EIGURE 5

WRIST PIN SUREACE PROEILES (K-REACTOR)

FIGURE 6

WRIST PIN SURFACE PROFILES (K-REACTOR)

EIGURE 7

WRIST PIN SURFACE PROEILES (NEW HATCH \& KIRK PIN) 


\section{FIGURE 8}

WRIST PIN SUREACE PROFILES

\section{EIGURE 9}

WRIST PIN SURFACE PROFILES PIN "A"

\section{FIGURE 10}

WRIST PIN SURFACE PROEILES PIN "B"

\section{FIGURE 11}

WRIST PIN SURFACE PROFILES PIN "C" AND "D"

\section{EIGURE 12}

COPPER CONCENTRATION IN IUUBE OIL GM-1K VS. ENGINE RUN TIME

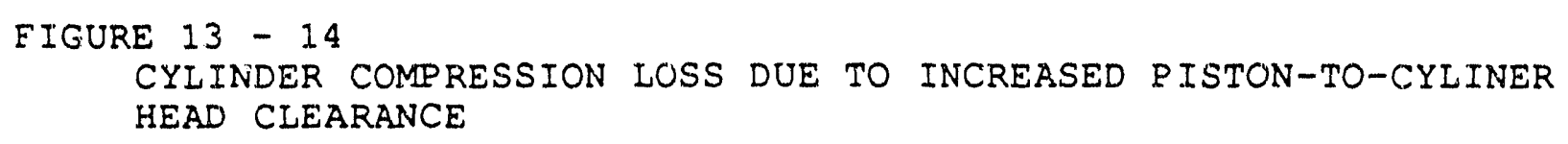

\section{EIGURE 15}

COMPRESSION PRESSURE TRENDS

FIGURE 16

GM-1K COMPRESSION DEVIATION

FIGURE 17

GM-2K COMPRESSION DEVIATION

FIGURE 18

COPPER CONCENTRATION IN LUBE OIL VS. ENGINE RUN TIME

\section{FIGURE 19}

AVERAGE FIRING PRESSURE GM-1K\& GM-2K VS. ELECTRICAL LOAD (KW)

\section{EIGURE 20}

AVERAGE EXHAUST TEMPERATURE TREND GM-1K, GM-2K VS. ELECTRICAL LOAD (KW)

APPENDIX A

ENGINE SPECIFIC TERMS

APPENDIX B

DR. IEE A. SWANGER-RESUME '

APPENDIX $C$

108-1K DIMENSIONAL CHECKS, 2/18/91

APEENDIX D

PAUL J . LOUZECKY-RESUME'

APPENDIX E

SURFACE EINISH OF METALS BY THE ASM COMMITTEE ON SURFACE FINISH 
APPENDIX $F$

EXPLANATION OF ARITHMETIC AVERAGE SUREACE EINISH

APPENDIX G

CSWE CONDITION REPORTS GM-1P AND GM-2P

APPENDIX H

CORRELATION OF COPPER CONCENTRATION IN LUBRICATING OII TO ACTUAL MEASURED BRONZE BUSHING WEAR

APPENDIX J

DATA ACQUISITION SYSTEM COMPUTER SCREEN

APPENDIX K

TYPICAL ENGINE READINGS DURING PERFORMANCE TESTING GM-1K AND $\mathrm{GM}-2 \mathrm{~K}$

APPENDIX L

MODEL 16-278A ENGINE PRESSURE DROP THROUGH EXHAUST PIPING

APPENDIX M

COMPRESSION PRESSURE ANALYSIS 
Technical.

Lifetime

GM Diesel

Cleveland Diesel

Model 16-278A

Rating

Operability

Failure

Bushings

\section{ENGINEERING EVALUATION OF THE GENERAL MOTORS (GM) DIESEI \\ RATING AND CAPABIIITIES}
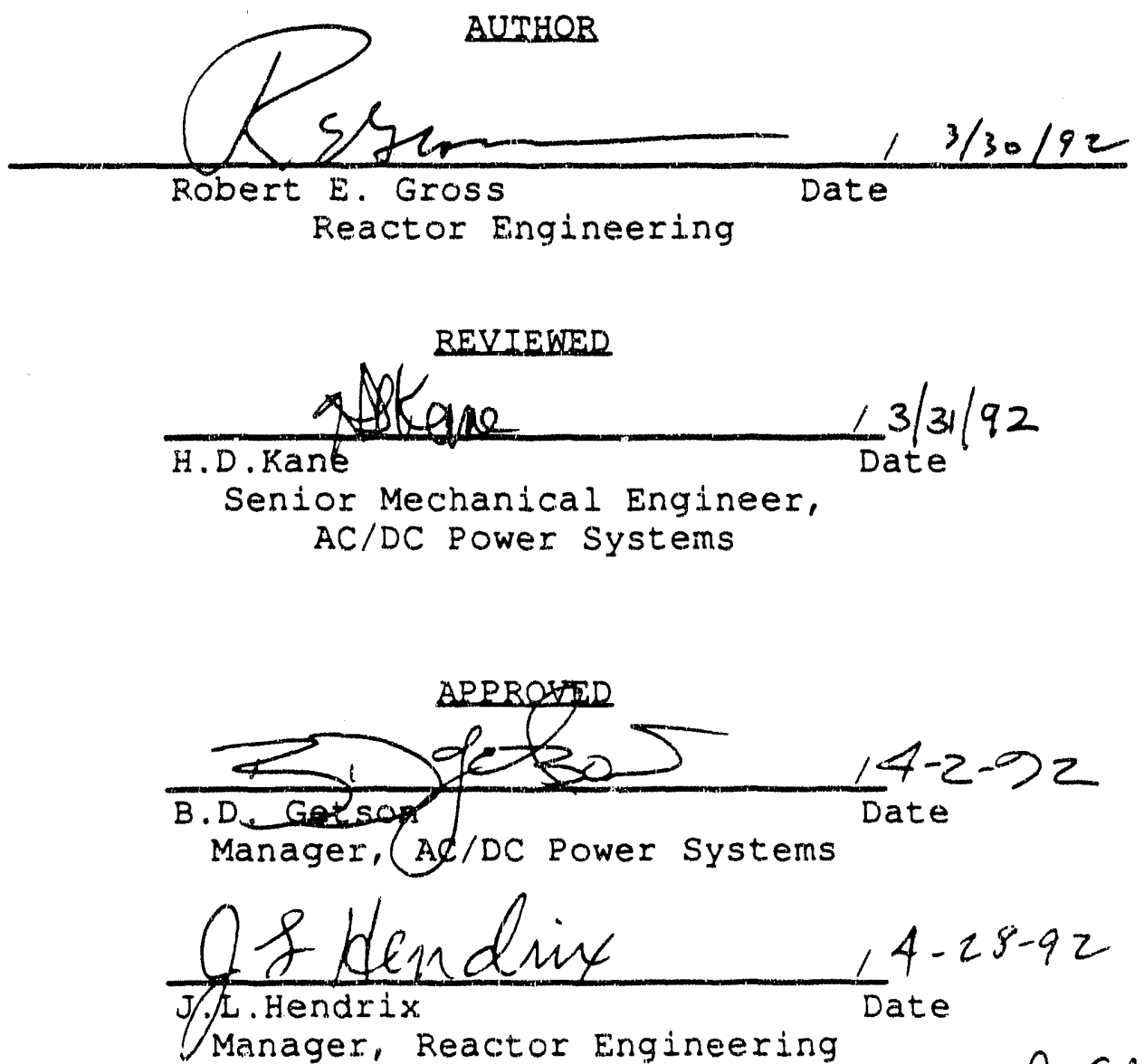

Design

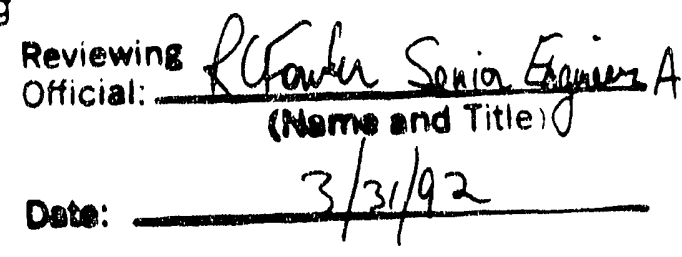


Date: $\quad$ March 20, 1992

WSRC-TR-92-42-011

Revision 0

To: F. Beranek, 704-C

From: R.E. Gross, 705-1C

ENGINEFRING DVATUATION OF TBF GFNARAT MOTORS (GM) DTFSFT BATING AND CAPABIITTIES (II)

\section{INTRORUCTION}

K-Reactor's number one GM diesel (GM-1K) suffered recurrent, premature piston pin bushing failures between July 1990 and January 1991. These failures raised a concern that the engine's original design capabilities were being exceeded. Were we asking old engines to do too much by powering $1200 \mathrm{kw}$ (continuous) rated electrical generators?

Was excessive wear of the piston pin bushings a result of having exceeded the engine's capabilities (overload), or were the recent failures a direct result of poor quality, poor design, or defective replacement parts? Considering the engine's overall performance for the past 30 years, during which an engine failure of this nature had never occurred, and the fact that $1200 \mathrm{kw}$ was approximately $50 \%$ of the engine's original tested capability, Reactor Engineering did not consider it likely that an overloaded engine caused bushing failures. What seemed more plausible was that the engine's failure to perform was caused by deficiencies in, or poor quality of, replacement parts.

The following report documents:

1. The results of $\mathrm{K}$-Reactor EDG failure analysis

2. Correlation of $\mathrm{P}$ - and C-Reactor GM diesel teardowns

3. The engine rebuild to blueprint specification

4. How the engine was determined ready for test

5. Testing parameters that were developed

6. A summary of test results and test insights

7. How WSRC determined engine operation was acceptable

8. Independent review of $1200 \mathrm{kw}$ operational data

9. Approval of the engines' $1200 \mathrm{kw}$ continuous rating.

\section{SUMMARY}

Research, analysis and testing by the GM Diesel Task Team have shown that the root cause of excessive wear and premature failure 
WSRC-TR-92-42-0.11

March 20, 1992

Page 2 of 20

Revision 0

of the piston pin bushings was inadequate, non-OEM-design replacement parts. The GM diesel premature bushing failures did net result from an engine overload.

Failure Analysis Associates (FaAA), the contractor primarily responsible for analysis of pin/bushing material properties, stated that the parts removed from K-reactor's GM diesel in January/February 1991 would have experienced premature failure at even $50 \%$ of the current load rating.

A $1200 \mathrm{kw}$ continuous rating is well within the original equipment manufacturer's (OEM) design envelope and actual factory tested capability. As a result, the Diesel Task Team concluded that it would be unnecessary to reduce the current continuous rating, to remove loads from the Emergency Bus, or to replace the current EDG installations with a larger capacity, more modern design.

Greater engine reliability and proper performance will be ensured due to future part's procurement and change-outs. Replacement parts will be purchased, inspected, and properly instalied in accordance with GM Cleveland Diesel blueprint specifications and assembiy procedures.

\section{BISTORY}

According to the original plant design, the Reactor building's emergency electrical power was to be provided by two General Electric A/C generators powered by General Motors (GM) Cleveland diesels. Gibbs and Hill, Inc. Architects \& Engineers of New York stated in the Project 8980 Savannah River Plant design notes, May 1953, that these engines had been factory tested satisfactorily to as high as 1831.5 brake horsepower (BHP) which corresponds to 1305 $\mathrm{kw}$.

General Motors Corporation's Cleveland Diesel Engine Division first designed the model 278A in the 1940's and sold the engine to the us Navy for submarine, tugboat, and minesweeper main propulsion and generator usage. The Model $278 \mathrm{~A}$ is an $83 / 4$ inch bore by $10 \mathrm{1} / 2$ inch stroke 2-cycle compression ignition diesel engine that is provided excess combustion air by a positive displacement blower. It utilizes four exhaust valves per cylinder to exhaust combustion gases as shown in figures $1 \mathrm{a}$ and $1 \mathrm{~b}$. The engine runs at an isochronous speed of 720 revolutions per minute (rpm).

Between 1986 and 1988, the generators were refurbished. The generator insulation was brought up to modern standards, and the capacity of the generator was increased to provide for future needs. The generators were rewound with National Electrical 
Manufacturers Association (NEMA) rated Class "F" insulated copper wire sufficient to obtain $1250 \mathrm{kw}$ continuous and $1335 \mathrm{kw}$ (2 hr) generator ratings at 0.8 power factor, reference 1 .

Preliminary load studies, reference 2, estimated one diesel's maximum load during certain accident scenario to be slightly over $1100 \mathrm{kw}$ for approximately 30 minutes. Therefore, Reactor Engineering considered it important to demonstrate $1200 \mathrm{kw}$ continuous duty capability as adequate insurance against overload. Each engine was overhauled at the same time its generator was being upgraded to ensure top performance and greatest reliability. After acceptance testing and engineering evaluation of all six. generating sets, recorded in RSP-88-011 for K-reactor, RTR 246y for I-reactor, and RSP-87-008 for p-reactor, the $1200 \mathrm{kw}$ continuous, $1250 \mathrm{kw} 2$-hour ratings were established.

\section{EAITURR CRRONOTOGY}

In July 1990, General Motors Diesel GM-1K compression readings, normaliy in the 550 to 650 psig range, were as much as 80 psig low on cylinders \#2, \#3, \#5, and \#10 as shown in figure 2 a. Compression readings are obtained by a 2000 psi kiene pressure gauge that senses the peak or maximum pressure developed in each cylinder. See definitions of engine- specific terms located in Appendix A. Maximum compression is developed at the top of the stroke or at the top of the pistun's travel in the cylinder, with exhaust valves closed, see figure $2 b$. Low compression is significant in that it could mean serious problems with a power pack. The assembly of cylinder liner, cylinder head, piston connecting rod (conn rod), conn rod bearing piston (wrist) pin and piston pin bushing is termed the "power pack". This assembly forms the pressure vessel in which air is compressed, fuel is injected and burned, and where the engine's power is developed; so "power pack" is an appropriate term.

\section{R-Reactor Engine Disassembly-Sept/oct 1990}

New power packs for cylinders $2,3,5$ and 10 were installed in September, 1990. Later that month, the Buna-N rubber o-rings used to seal the cylinder liners to the jacket water rings were found leaking and had to be replaced. In early October, GM $7 \mathrm{~K}$ was operated at $1150 \mathrm{~kW}$ for approximately 48 hours to complete CSWE's guarantee work package. On October 24 , all 16 cylinders were again removed for disassembly to investigate low lube oil pressure problems, and to further investigate the abnormal bushing wear on previously removed cylinders 2, 3, 5, and 10. Engineering's initial evaluation was that the cause of excessive bushing wear was bad parts. 
WSRC-TR-92-42-011

March 20, 1992

Eage 4 of 20

Revision 0

\section{K-Reactor Engine Assembly-Nov 1990 thru Jan 1991}

In mid-November, another assembly of new power packs was nearly complete using replacement parts furnished by the vendor Hatch and Kirk, Inc, of Seattle, Washington. Problems encountered during assembly included bent connecting rods, wrong desion oil control rings, poor fitting gasket.s, porous lube oll pump casting, rocker shaft stands that broke when installed, new cylinder heads with casting sand and wire lodgea in the water passages, and new fuel injectors that failed within hours of installation on the engine. In January 1991, fuel rack settings were adjusted to achieve rated load, and the $1200 \mathrm{~km}, 48$ hour load test was begun. Compression readings taken at the end of the run showed cylinder number 14 again low. Figure 3 shows very graphically the drop in pressure on cylinders $2,3,5$, and 10 in July 1990 and on the number 14 cylinder in January 1991 when compared with the average of all 16 cylinders. On February 9 , the number 14 cylindex head was replaced to remedy a suspected exhaust valve seat problem, but the compression did not increase appreciably.

\section{K-Reactor Engine Disassembly-Eab 1991}

Eurther disassembly of GM IK to detexmine the source of thr low compression continued from February 15 to 17 . The wear orserved on the number 14 piston pin bushing was similar to that seen in the October 1990 failure, so four additional packs were disassembled, numbers $5,6,7$, and 16 , to determine their condition.

\section{GM Diasel Task peam Crented}

A GM diesel Task Team was formed on February 18, 1991 consisting of Reactor Engineering (RE), Reactor Quality (RQA), Equipment Engineering Services (EES), Central Services works Engineering (CSWE), and site Engineering and Services-Quality verification (SES\&Q'), representatives. Their task was to provide two tested and operable diesel generators for kn-reactor restart.

On February 22, the lollowing independent consultants: Dr, Lee Swanger from Failure Analysis Associates (FaAA), and Messrs Bob Gustafson and Greg Flynn from Trident Engineering Associates, Incorporated, were asked to aid Reactor Engineering in determining the root cause of GM-1K piston pin bushing failures. On Eebruary 26, one of the original GM Cleveland Diesel design team members, Mr. Paul Louzecky, was also contacted. 
WSRC-TR-92-42-011

March 20, 1992

Page 5 of 20

Revision 0

\section{EATIURE ANATYSIS}

\section{Tailure Analysis Associates (FaAA)}

Results of the K-Reactor GM root cause failure analysis are contained in a report prepared by Dr. Lee Swanger, Principal Engineer and Director of the Miari officer of EaAA. His background includes past failure analyses of aluminum main bearings on Fairbanks Morse@ opposed pistion engines and crankshaft torsicnal vibration problems on the Transamerica Delaval Enterprise engines, see appendix $B$. To summarize, his report on the GM diesel. engine bushing failures identified the unpolished surface finish profile of the alloy steel piston pins as the primary cause of accelerated bushing wear. A strong contributor to the premature and recurrent fallure was inadequate tin plating on an inferior gear bronze alloy core piston pin bushing. The few bushings that had not failed were of rederal Mogul (IM) manufacture meeting all. GM Cleveland's plating and material specifications. Federal Mogul (FM) is considered by experts to be one of the country's finest bearing manufacturers, and in the 1950's qualified as one of Cleveland's original wrist pin bushing suppliers. The non-FM piston pin bushings were worn as much as 0.120 inch on the diameter of 3.004 inch, lowering compression pressures up to 80 pounds per square inch (psi), see inspection report appendix $C$. Figure 4 shows how these excessive clearances can cause low compression pressures.

FaAA also performed a journal orbit analysis (JOA) which evaluated the bushing and bearing lubrication regimes at $1075 \mathrm{kw}$ and 1200 $\mathrm{kw}$. JOA is the study of the eccentric path of a shaft as it travels or orbits in a bearing journal. The analysis itself seeks to solve the Reynolds equation, a two-dimensional second order differential equation, by numerical techniques. Estimated oil film thickness was nearly identical for both load cases, varying no more than 3 f from the lower to the higher load. FaAA summarized that, even though the bushings' oil films were very thin and boundary lubrication regimes existed, the original design was adequate. In fact, the model 278A's excellent operational track record since the $1950^{\prime}$ 's supported the original design's adequacy.

\section{Engineered Applications Corp (mAC)}

According to Mr. Paul Louzecky of EAC, Savannah River Site was provided parts that did not meet the original Cleveland design criteria. Paul, who is now an independent consultant was chief engineer at the Cleveland Engine Division of General Motors Corporation from 1935-1958, see Appendix D. He confirmed that Cleveland's original piston pin surface finish design criteria of "grind lap $O D$ (outside diameter) for a surface finish of 4 micro 
WSRC-TR-92-42-011

March 20, 1.992

Page 6 of 20

Revision 0

inch (Hin) then polish to a mirror finish..." was essential for busbing longevity. Appendix $E$ includes other data being accumulated by engine designers ca 1955, and supports the technical argument for a smooth polished bearing surface to maximize load-carrying capability. Paul aiso confirmed bushing oil groove geometry, surface finish and tin plating thickness as critical parameters.

\section{Trident Engineoring Associates, Inc (TEA)}

Independent consultant Mr. Bob Gustafson of Trident Engineering Associates, Inc. corroborated these staliements. Mr. Gustafson, a Mechanical Engineer formerly with the us Naval Engineering Experiment Station at Annapolis, Maryland, is considered an expert in marine engineering, vibration related machinery problems, and specializes in large, medium speed diesel engine repair. His study of the disassembled engine parts and data concluded that the piston pins were a ground, not polished finish, and that the bushings had failed because the lubricating oil groove geometry did not meet OEM requirements.

\section{Batch and Rirk, Ine. (HGK)}

The vendor $H \& K$ was consulted for their views and comments on the multiple failures. Treir opinion was that the engine had experienced an overload situation, and that the bushings were never intended to operate in the model $278 \mathrm{~A}$ at that $(1200 \mathrm{kw})$ power level. However, this opinion was based on their successful experience servicing the Model 16-2.78 A operated at $1000 \mathrm{kw}$ maximum continuous load. After lengthy review and investigation of their position, WSRC determined that it was not supported by original design experts, such as Messrs. Louzecky, Gustafson, nor the evaluation of FaAA, inc. The H\&K position (i.e., $1200 \mathrm{kw}$ continuous was an overload condition) was a primary factor in the RRD's decision to undergo a rigorous rebuild and test program.

\section{R-_C-_ ANR I-BEACTOR ENGINE DISASSFMBIX}

\section{General}

Disassembly of P-Reactor GM diesels in mid-March 1991, and CReactor GM diesels in May to salvage used cylinder liners, connecting rods, and pistons were to provide further data supporting the GM-1K root cause failure analysis. A ground, unpoiished piston pin surface finish was confirmed as the primary cause for premature bushing wear. Even though both p-reactor engines had relatively the same amount of hours at $1200 \mathrm{kw}$ load, " $3 \mathrm{~N}$ " brand piston pin bushings (non-FM) installed in the 108-1P engine performed satisfactorily with smooth surface Finish pins. 
WSRC-TR-92-42-011

March 20, 1992

Page 7 of 20

Revision 0

The 108-2P bushings of various manufacture (non-FM) coupled with rougher finished pins were worn excessively. 108-1C piston pin bushings exhibited normal wear because the OEM installed piston pins had a polished surface finish.

\section{surface Finish Measurements}

American National Standards Institute (ANSI) B46.1-1962, Revised 1971 , is a standard for measurement of surface roughness, and specifies that machined surfaces be me sured in microinch or $1 x$ $10-6$ inch arithmetic average (AA), or roughness average (Ra). Appendix $F$ and Table 1 are taken from FaAA's failure analysis report. Appendix $E$ explains that $A A$ is average deviation from the mean surface, and that the average peak-to-valley height can be roughly 4 times the $A A$ reading. Table 1 presents the tabulation of relative surface finish roughness found on new versus used piston pins. Note that the first five pins identified were removed from $G M-1 K$, and are similar in surface finish to the new H\&K pin.

\section{$\mathbf{P}-\mathbf{A} \mathbf{x} \boldsymbol{Q}$}

Fins " $A$ " and "B" removed from GM-2P, had maximum surface finish peaks of 35 microinch ( 8 microinch $A A)$, while pins "C" and "D" removed from GM-1P, had measured maximum peaks of 11 microinch ( 3 microinch $A A)$. All the pins removed from P-Reactors GM-1P were etched with a "B-N" identification on the pin's ends. They are believed to have been manufactured by Burgess Norton. Burgess Norton is a major U.S engine parts supplier and premier piston pin manufacturer/designer. They were considered to be the GM Cleveland Diesel Division's preferred wrist pin vendor.

Eigures 5 thru 11 are taken from the FaA report and show the actual contour (profile) of a portion of each pins surface. High roughness 'peaks' or asperities on the finish of the piston pins (seen as tall spikes on the strip charts) are normaily removed during a polishing oporation, but axe readily apparent on all but the $B-N$ brand and the new Japanese pin. This critical machine process was omitted on pins $1,2,5,7$, and 11 , as seen in figures 5 and 6 . Figure 8 shows that the profile of a polished pin has no large peaks in the finish, i.e., they are flattened or smoothed off. A review of CSWE condition reports, Appendix G, confirms that, even though both $P$-reactor engines had relatively the same amount of run time at $1200 \mathrm{kw}$ load, the "3N" brand piston pin bushings from 108-1P engine performed satisfactorily with smooth surface finish pins while the 108-2P bushings were worn excessively. Several bushings from GM-2P were actually seized solid in the rod eye indicating total failure of the "full floating design" wrist pin bushing. 
WSRC-TR-92-42-011

March 20, 1992

Page 8 of 20

Revision 0

\section{$C-\mathbf{A} \mathbf{a}$}

The 108-1C reactor engine was determined to have operated approximately 5000-7000 hours :Ince 1953 by assuming 1.50-200 operating hours per year. Another estimate can be deduced from measured wear on a typical cylinder liner-assuming constant rate of wear over the liner's life. c-reactor's liners were measured by SES \& QV to be in most cases 0.002"-0.003" over standard size. According to the GM Maintenance Manual, an 0.008" increase in liner diameter corresponds to the expected liner wear (the wear limit) over 14000 hours. Therefore, a liner diameter measurement of 0.003" oversize would give an estimate of 3/8 (14000)=5200 hours of operation. 108-1C piston pin bushings exhibited normal wear because the original cleveland piston pins, installed at the time of manufacture, had pelished surface finishes measured at 5 microinch AA. Also, piston pin bushings in this engine were of the Federal Mogul brand. FaAA verified by laboratory analysis that FM bushings were the only bushings analyzed out of the five different brands studied that met all chemical, physical, and mechanical properties specified in the original GM design.

\section{I-Area}

One question troubling team members was why the I-Area GM diesels did not have the same problem (with low compression and high copper concentration in the lubricating oil samples) as K-Area. The I-Area GM diesels had accumulated roughly 50 hours functional testing at $1200 \mathrm{kw}$ after generator rewind and another 50 hours a year at $1200 \mathrm{kw}$ to total $300-400$ hours per diesel by 1992 . How could the same unacceptable parts that failed in K-Area engines operate successfully in L-Area engines at the same "high" load?

The I-Area GM's were reported to have undergone an "overhaul" during generator upgrade in 1985/86, just prior to the overhaul of P-Area and K-Area engines. Since Hatch and Kirk, Inc. (H\&K) purchased the GM Cleveland line in 1977/1978, it is possible that they supplied GM parts for I-Area GM rebuild.

In May of 1991, a liner seal (cylinder *6) was confirmed as the source of a jacket water leak into the crankcase of GM diesel 108II. Over the next few months the power pack was removed, and individual components were examined. Visually, the no-name piston pin was in very good condition with an SRL measured surface finish of 5 microinch $A A$, the same as C-Area pins, and surface hardness of 59 Rockwell "C" (RC) scale (spec is 58 Rc). One peak/valley (probably a scratch or burr) measured 68 microinch AA. The majority of the pin's surface finish profile, however, measured in the 2-5 microinch range.

The Federal Mogul piston pin bushing which had been mated with this particular piston pin showed wear quite similar to C-Area GM 
WSRC-TR-92-42-011

March 20, 1992

Page 9 of 20

Revision 0

diesel ( 5200 hours). The outside diameter of the piston pin bushing measured $0.0003^{\prime \prime}$ undersize (3.8715"), and the inside diameter 0.0008 " oversize (3.0053") from new parts specifications. Reference 15 specifies the inside diameter wear limit as 3.012". Based on a 14000 hour engine design life and assuming even wear, this bushing is estimated to have operated $0.0008 / 0.0075 \times 14000=$ 1500 hours in GM-1L.

Bushing surface finish, hardness, concentricity, cil groove geometry and plating thickness, were found to be acceptable. Detailed chemical and metallurgical analyses of the bushing were not performed because $F$ aAA had already verified by laboratory analysis that FM busings met all chemical, physical and mechanical properties specified in the original Cleveland design.

According the both CSWE and RE personnel involved in the 1986 rebuild efforts, only parts that did not meet Reference 15 size criteria were replaced. Cylinder liners and piston rings were reportedly replaced due to lube oil consumption problems, but pistons and connecting rods were probably re-used. It is possible that original Cleveland piston pins and bushings were never replaced, and still remain in the $L$-Area engines today. It is also plausible that rebuild parts were provided from cleveland surplus rather than from a modern-day aftermarket vendor.

\section{EINAT R-REACTOR GM ENGINE ASSEMBIY}

Because a clear correlation between engine failure and nonspecification parts was clearly established, the GM Diesel Task Force strove to procure, recondition, inspect, and assemble the power packs as nearly as possible to cleveland's original blueprint design. Drawings were obtained from Mr. Louzecky, the U.S. Navy, and even Hatch and Kirk from which CSWE and RSE derived reference 3 .

- Cylinder liners were sent to an offsite vendor for honing with a crosshatch or diamond pattern to prepare them for new piston ring break-in. This is an industry recommended practice and was done so that the cast iron piston rings would "wear-in" or conform to the chrome liner surface without galling or scuffing and seat tightly to prevent combustion gas leakage (blowby).

- Connecting rods were sent to an Rlbany, Georgia machine shop to finish the small end, or eye, of the rod with diamond hones to the proper 4 microinch $A A$ surface. As received from the current parts supplier, the conn rod eye finish was in the 3570 microinch AA range. This, according to Paul Louzecky had caused excessive wear on the outside diameter of the piston pin bushings in a similar way that the rough finish on the piston 
WSRC-TR-92-42-011

March 20, 1992

Page 10 of 20

Revision 0

pins had worn the inside diameter of tine piston pin bushings. Wear on the outside diameter of the piston pin bushings also increases total clearance and causes loss of compression.

- Off-the-shelf piston pins were obtained from the Navy supply system and from Hatch and Kirk, Inc. They were then superpolished in the $717 \mathrm{~A}$ machine shop and inspected at the Savannah River Lab for conformance to the drawing's mirror Einish specification of 1.5-2 microinch AA.

- As recommended by FaAA, only Federal Mogul brand piston pin bushings were used in the 32 power pack assemblies. Approximately 100-150 bushings were inspected and sorted to obtain the best 32 that most closely conformed to GM's Cleveland design.

- Only ten new pistons were availab e, so the $P, C$, and used KReactor pistons were cleaned, inspected, measured and evaluated until the best 32 were chosen to rebuild GM-1K and GM-2K.

Deviations from reference 3 criteria were documented and dispositioned through Nonconformance Reports (NCR), references 4 thru 7. GM-1K diesel assembly was completed 5-1-91, and GM-2K was assembled by $6-1-91$.

\section{TRE PRE-TEST FUALUATION}

WSRC Reactor Engineering performed an engineering evaluation of the pre-test engine configuration prior to actual performance testing. At the Reactor Restart Division Vice President's staff meeting in May, 1991, the following subjects were discussed:

- The US Navy historical data and technical documents

- The Cleveland design and original factory testing

- Review of the root cause analysis and (JOA) results

- Break-in testing schedules

- Critical performance indicators

- Independent consultant statements of support.

\section{- US Navy bistorical data and tachnical documents.}

Through historical data files kept by the US Navy at the Naval Ships systems Engineering station in Philadelphia, $P A$, we found records of an 1800-2000 bhp rated model 16-278A engine being sold to the US Navy. See Table 2.

Technical manuals, references 8 thru 11 , aided in defining an acceptable operational envelope. The US Navy still operates the model 16-278A on their aircraft carriers; the USS Forrestal CV-59, USS Saratoga CV-60, and USS Rarger CV-61, as emergency diesel generators rated at $1000 \mathrm{kw}, 150 \mathrm{r}$ bhp. 
WSRC-TR-92-42-011

March 20, 1992

Page 11 of 20

Revision 0

\section{- The original cleveland design and factory testing data.}

Original factory design and testing data was provided by PJ Louzecky, some of which is included in reference 12 . The records show that the engine was operated for over 2500 hours at 2400 to 2800 bhp with an identical piston pins and bushing design. According to Cleveland's records, all parts met blueprint specification for material composition, geometry and surface finish. Appendix $A$ of reference 12 discusses operation of this engine at 3900 bhp with blowers and De Laval turbocharger.

\section{- Raviow of the root cause failure analysia and discussion of (JOA) results.}

The Journal orbit Analysis (JOA) results and root cause failure analyses were again reviewed. The two different power levels, $1075 \mathrm{KW}$ and $1200 \mathrm{KW}$, had been analyzed in order to determine, theoretically, whether the oil film was appreciably thinner at the higher load, possibly contributing to this failure. Theoretical minimum oil film thickness (MOFT) according to EaAA results, was 21.9 microinches at $1075 \mathrm{kw}$, and 21.3 microinches at $1200 \mathrm{kw}$. Due to simplifications required for the computer models, Dr. Swanger stated that the computer most likely overestimated the actual piston pin/bushing oil film thickness. It is probably one-fourth $(1 / 4)$ the theoretical value ( 5 microinch); the difference in thickness at $1200 \mathrm{kw}$ vs $1000 \mathrm{kw}$ being negligible.

Dr. Swanger concluded that the increased power demand on the engines had little to do with the accelerated bushing wear problem. But, since the oil film is thin, assemblies are sensitive to conditions which would disrupt the film. Those conditions would include rough piston pin surface finish, inferior bushing metallurgy, poor casting techniques, and inadequate breakin (tin or tinllead) coating. Dr. Swanger stated that the GM diesel. would have experienced reduced bushing life and premature failure at even $50 \%$ of rated load, although the degradation would not have been as rapid as we had experienced.

Lubricating oil pressure, bulk oil temperatures, and even oil brand-type used were found adequate by FaAA and RE. Reference 16 is a comprehensive review of our decision to use engine lube oil containing zinc dithiophosphate as an anti-wear additive in lube oil. The use of low-zinc oil is advocated by railroad diesel experts because high zinc oils promote chemical attack on the Electromotive diesel (EMD) engine's silver-coated bushings.

\section{- Proposal for break-in testing schedules.}

The proposed engine break-in schedule followed guidelines of the GM maintenance manuals and those of reference 11. It is important to bring load quickly onto a diesel engine, especially one with 
WSRC-TR-92-42-011

March 20, 1992

Page 12 of 20

Revision 0

chrome plated liners. If high loads are applied too quickly, mating parts do not have adequate time to seat or conform to each other. The result can be excessive friction and heat, possibly metal fatigue and premature failure. Slow application of load causes other problems for the rings especially as they glide over, rather than seat, to the chrome-plated liner surface. If this happens, the rings do not complete the tight gas seal necessary for efficient running and low lube oil consumption.

$R E$ and CSWE planned to increase load to nearly $1000 \mathrm{kw}$ before accomplishing the necessary head bolt re-torque. This operation is similar to re-tightening the head bolts on automobile engines after head gasket replacement. Gasket relaxation and bolt slippage (part of the torque originally applied in a joint is taken up by internal-to-external thread friction the ${ }^{*}$ later relaxesl are overcome by this operation, and proper pre-load is placed on the cylinder head deck joint.

Following head bolt re-torque, the engines would be operated for approximately 50 hours at $1075 \mathrm{kw}$, followed by another 50 hours at $1200 \mathrm{kw}$. This last operation included RSP, RTIR, and Nuclear Regulatory Guide 1.108 testing for 24 hours continuous at $1200 \mathrm{kw}$ with 2 holus at $1250 \mathrm{kw}$, the engine's original 2-hr rating.

\section{- Development of critical performance indicators.}

Three "key performance indicators" would be monitored during testing and utilized to evaluate bushing wear without engine disassembly:

1) Amount of elemental copper flakes in the oil.

2) Metal wear particle shape, size and composition.

3) Individual cylinder compression pressure trends.

1) Ameunt ef elemental copper flakes in the Qil. Appendix $\mathrm{H}$ is a calculation done to quantify theoretical copper concentration in parts-per-million by weight $\left(\mathrm{ppm}_{\mathrm{w}}\right)$ using actual bushing metal loss (by geometric measurement), and known amount of oil in the GM lube oil system. The results indicate that the laboratory reported copper concentration levels are one-sixth of the calculated bushing material lost.

There are numerous variables to consider to explain the lack of correlation. The calculation does not account for other known sources of copper wear particles; in other words, it assumes all the copper in the sample results had come from the worn piston pin and rocker arm bushings. Size and dispersion of wear particles affects what is captured in a sample bottle and subsequently sent off for spectrometric analysis. Also, the oi. filter traps particles greater than about 15-25 micron (10 EE - 6 meter), so larger particles caught in the filter are not. included in laboratory results. For that reason predicting 
WSRC-TR-92-42-011

March 20, 1992

Page 13 of 20

Revision 0

actual bushing measurements using laboratory wear metal analysis was considered unreliable.

However, a level of 30 parts-per-million (ppm) rise in elemental copper for the first 100 engine hours was established as a threshold or warning level based on a review of our own empirical data, and after consulting with the Naval Engineering Station at Philadelphia and their Virginia research lab. Figure 12 shows expected levels based on US Navy data. Exceeding the threshold criteria would have caused $R E$ to investigate premature bushing deterioration.

2) Metal wear particle shape, size and compesitien. Ferrographic oil analysis, which is the study of the size and shape of wear particles in lubricating oils, was to be used as the second key indicator of bushing condition. If abnormal (copper) cutting wear or fatigue wear particles appeared in the lube oil samples, they could indicate abrormal damage to the wrist pin bushings.

3) Individual cylinder compression pressure trends, Loss of compression greater than 40 psi on a particular cylinder over its last set of readings was the third key indicator of bushing condition. Theoretical correlations that exist between compression loss and piston-to-cylinder head clearance increase are shown in figure 13. Again referring tc figure 4, this increase in piston-to-cylinder head clearance results from the shorter stroke of the connecting rod due io increased bushing clearance, both in the rod eye and between the bushing and pin. one can imagine the connecting rod moving relative to the piston. This is the lost motion and resultant larger clearance space evidenced by reduced compression pressures.

Good prediction of compression pressure loss occurs at clearance values of $0.050-0.100$ inch $(50-100 \mathrm{mils})$, but it can be seen in figure 14 that the prediction at or near the bushing's wear limit $(20 \mathrm{mils})$, is not as good. Normal compression readings on a rebuilt engine typically start near 520-550 psig and trend upward as the parts break-in. It is not uncommon to have $20 \mathrm{psig}$ variations in peak readings on any one cylinder as a function of time using the same kiene gauge, so the key indicator was set at 40 psig drop from previous readings to avoid confusion with normal variations in accuracy, and because good empirical correlation existed with larger drops in compression. Compression trend data, taken every 20 hours, provided another means to indirectly monitor bushing condition. 
WSRC-TR-92-42-011

March 20, 1992

Page 14 of 20

Revision 0

\section{- Independeat consultant statements of support}

Consultant statements of support were presented at the May 1991 RRD staff meeting and summarized as follows:

- Dr. Swanger, FaAA, reviewed the JOA and metallurgical analyses, and confirmed that OEM designed parts would be capable of $1200 \mathrm{kw}$ continuous, $1250 \mathrm{kw} 2$-hour operation.

- P.J. Louzecky, the OEM engine designer, said that 1) the GM 16-278A was factory tested at $>2000$ bhp with the same parts (wrist pin and bushing) as SRS has installed, 2) from his own personal experience at GM Cleveland he knows that this engine has the design capability for $2400 \mathrm{bhp}(1700 \mathrm{kw})$ and beyond, and 3) after his personal review of procedures, observations of engine assembly, and inspection of rebuild parts he considers the engine assembly acceptable and to be within OEM guidelines.

- Bob Gustafson, said that Trident considers the present rating and proposed operation to be acceptable provided we used OEM specified parts.

- Herb Waite, Hatch \& Kirk, Inc. said he had no records of this engine operating for any length of time at $1200 \mathrm{kw}$, since all the original GM testing documents were lost. To the best of his knowledge, the engine was generally not marketed or sold at ratings above $1000 \mathrm{kw}$. He stated that he would like to review data after operation, and would like to see 1000-2000 hours testing at $1200 \mathrm{kw}$ before being comfortable with the $1200 \mathrm{kw}$ continuous rating.

Reactor Engineering concluded the engine's current configuration was ready to test.

\section{TEST RESUITS}

\section{General}

GM-1K was load tested from $5 / 15 / 91$ to $5 / 25 / 91$, and $G M-2 K$ was tested from $6 / 4 / 91$ to $7 / 1 / 91$. Test results are included in references 16 and 17 . Appendix $J$ is a printout of the Data Acquisition system computer data screen. For a summary of typical engine performance, see Appendix $K$. Compression data and lube oil analysis are presented in figures 15 thru 18. All wear metal particulate analyses indicated normal break-in wear. Compression was as expected for the amount of engine hours allowed to initially seat compression rings. 
WSRC-TR-92-42-011

March 20, 1992

Page 15 of 20

Revision 0

\section{Data Acquisition}

The Equipment Engineering Section (EES) of the Savannah River Laboratory (SRL) installed a data acquisition system (DAS) at Reactor Engineering's request to monitor generator voltage, current, frequency, engine temperatures, pressures and flows. Those parameters are designated "C" ("computer monitored") in Table 3. Appendix J, provided courtesy of H.T. Sessions and S.L. Collins, shows the Macintush II ronitor screen as it appeared during testing. Their customid program utilized labview Software and stored the data once per minute on hard disk. Instrument specifications, analog devices and signal conditioner details are included in SRL-ELC-910260 under Job Number 22-035.

\section{Engine Parameters}

Firing pressure and exhaust temperature are important parameters used to monitor engine performance and to balance engine horsepower between cylinders. The limits to maintain when at the $1200 \mathrm{kw}$ power level are $900^{\circ} \mathrm{F}$ maximum em haust temperature, $200^{\circ} \mathrm{F}$ cylinder-to-cylinder exhaust temperature variation, and $1050 \mathrm{psig}$ maximum firing pressure. According to studies done by and for the US Navy by the OEM, cylinder-to-cylinder firing pressure variation should be held to 50 psi in order to maintain comparable cylinder wear and stress. Reactor Engineering accumulated data in February, 1991, that could be used to better understand the significance of the pressure variations.

I-reactor GM diesel firing pressure data was taken with a Beta Engine Analyzer, a device that records the pressure variation in a particular cylinder as a function of time and crankshaft angle. The resulting indicated mean effective pressure (imep) plots and calculations at $1200 \mathrm{kw}$ record that GM-1L cylinder \#3 vs \#16 offbalance of $B O \mathrm{psi}$ was equivalent to $14 \mathrm{hp}$ or $11 \%$ difference between cylinders. GM-2L cylinder imep variation (\#1 vs \#13) of 75 psi was equivalent to a $17 \mathrm{hp} \mathrm{(14 \% )} \mathrm{imbalance.} \mathrm{This} \mathrm{power}$ imbalance must be minimized to reduce vibration and crankshaft stresses and to promote even wear of components.

According to Paul Louzecky, the US Navy was successful balancing to the 50 psi criteria when operating at $1000 \mathrm{kw}$. However, at $1200 \mathrm{kw}$ it was much more difficult to maintain cylinder firing pressures within 50 psi. A $15 \%$ imbalance between cylinders on the Model 278A was considered by him to present no problem.

\section{Firing Pressures}

GM-2K firing pressures were higher than GM-1K at comparable load, see figure 3.9 , and proved to be more difficult to balance. GM-2K may have been had to overcome slightly more friction horsepower (fhp) than GM-1K (normally about $460 \mathrm{hp}$ ). It is also probable that actual ( $\mathrm{kw}$ ) load for $\mathrm{GM}-2 \mathrm{~K}$ was more than indicated (by $40 \mathrm{kw}$ ) 
WSRC-TR-92-42-011

March 20, 1992

Page 16 of 20

Revision 0

for part of the test due to meter inaccuracy. Both increased fhp and $40 \mathrm{kw}$ increased electrical load would be evidenced by elevated firing pressures, which was the case. In other words, it would require slightly more mean effective pressure (mep) during the power stroke to overcome increased fhp and/or added kw. Cylinderto-cylinder firing pressure variations at $1200 \mathrm{kw}$ were held to 50 psi on GM-1K, but were increased to 80 psi GM-2K.

\section{Exhaust Temperatures}

\section{Problem with GM-2B}

GM-2K average exhaust temperature was slightly elevated as shown in figure 20 . At $1200 \mathrm{kw}$, cylinder \#14 was running the hot test at $880^{\circ} \mathrm{F}$ while cylinder \#5 was running the coolest at $630-650^{\circ} \mathrm{F}$ with 50 psi difference in firing pressures. These readings are near the OEM design limits of $900^{\circ} \mathrm{F}$ max, any cylinder, and over the $200^{\circ} \mathrm{F} \max$ allowable variation cylinder-to-cylinder.

\section{Adjustments}

By increasing the allowable firing pressure spread between cylinders, pressure can be either jncreased or decreased within the allowable spread. If a hot cylinder is also running a high pressure, as with \#14, one way to bring the temperature down is to reduce firing pressure. This is normally done by reducing the Fuel quantity delivered to individual injectors. Since the hot cylinder is then receiving less fuel, it delivers less horsepower, and it should cool. Cylinder $\$ 14$ exhaust temperature dropped to $830^{\circ} \mathrm{F}$ while cylinder $\$ 5$ warmed to $670^{\circ} \mathrm{F}$ following the decision to increase firing pressure variation to 80 psi. This satisfied all engine design limits, and allowed room for the expected rise in exhaust temperatures and firing pressures during the $1250 \mathrm{kw}$ (2hour rating) test.

\section{Insights inte the problem}

- Raw water temperatures were higher from May to July $\left(67^{\circ} \mathrm{F}\right.$ vs $\left.77^{\circ} \mathrm{F}\right)$. Average inlet air midday temps are estimated at $80-90^{\circ} \mathrm{F}$ from unofficial RE logbook entries. These ambient temperature differences may have contributed to elevated exhaust temperatures.

- Average temperatures and pressures over time are not significantly different for the two k-reactor engines. Individual cylinder exhaust temperatures, especially GM-2K cylinders \#5 and \#14, showed wide variation $\left(200^{\circ}-230^{\circ} \mathrm{F}\right)$, indicating possible scavenging problems.

- A higher exhaust manifold pressure (32 inches water on GM-2K vs. 16 inches water, $G M-1 K$ ) and lower air charging (blower) pressure $(2-2.5$ psig on $G M-2 K$ vs $3-3.5$ psig for $G M-1 K)$ could have contributed to the difference in scavenging of $G M-2 \mathrm{~K}$ operating above $1000 \mathrm{kw}$. 
WSRC-TR-92-42-011

March 20, 1992

Page 17 of 20

Revision 0

- Appendix $I$ is an analysis of $G M-1 K$ and $G M-2 K$ exhaust piping configurations. According to WSRC engineers measurements and Mr. Louzecky's calculations, K-reactor GM exhaust piping designs are acceptable. However, some choking of the exhaust is possible due to the pipes' length causing excess backpressure by reflecting wave. Since both piping runs were found to be nearly identical, similar backpressure and engine response due to choking would be expected at high load. However, if one exhaust muffler was more restricted than the other, e.g., clogged with carbon deposits, then that could account for the higher backpressure.

\section{Condition is Acceptable}

According to the GM maintenance manual, reference 15,40 inches of water exhaust backpressure, and 80 psi cylinder-to-cylinder firing pressure variations are acceptable design values provided other parameters are not exceeded.

\section{TEST EYATUATION}

After review of the test results and performance indicators, WSRC engineers and independent consultants determined that the $1200 \mathrm{kw}$ GM testing was successful, and concluded that:

a. The engines reached full power and operated successfully within the limits of temperature and pressure specified by US Navy operation's manuals, PJ Louzecky's OEM test stand data, and the original SRS GM Cleveland Diesel maintenance manuals.

b. We received no indications of premature bushing failure from key performance indicators, i.e., bulk copper <14 ppm over 100150 engine hours.

c. Compression pressures were steady and on an increasing trend.

Therefore, there was no need to teardown and inspect the engines due to suspicion of bushing failure

\section{THE CONSUITANTS' BEVIEH}

Independent review of the operational data was performed post-test by the various consultants. PJ Louzecky provided comments detailed in reference 12. Dr. Swanger and Mr. Louzecky reviewed the compression readings with $R E$ verbally by telephone and sent Appendix $M$. Trident associates reviewed their comments with $R E$ on the phone. Their comment was to continue to monitor the air box pressure on the $G M-2 K$ as it showed lower than GM-1K. In their 
WSRC-TR-92-42-011

March 20, 1992

Page 18 of 20

Revision 0

opinion, this could be due to excess clearance in the blower, but at present is not cause for concern.

Hatch and Kiry. Inc. again commented that they would have liked to have seen at least 1000 hours run time on the diesels before being fully comfortable with $1200 \mathrm{kw}$ operation.

Copies of typical data at various loads were also sent to the US Navy at the Puget Sound Naval Shipyard in Bremerton, washington and to the Naval Engineering Station in Philadelphia. According to these sources, the data looked normal and consistent with their Cleveland model 278A diesel engine operation at comparable loads.

\section{conchtistox}

The GM diesel's $1200 \mathrm{kw}$ continuous rating and its capabilities were re-established. The k-reactor emergency diesel generators in their present configuration were presented to DOE under Operational Readiness Review (ORR) and Office of Nuclear Safety (ONS) review. They were accepted as having the capability for $1200 \mathrm{kw}$ continuous, $1250 \mathrm{kw} 2$-hour ratings. GM-1K and $\mathrm{GM}-2 \mathrm{~K}$ diesel generators were declared operable for Restart.

\section{comatrumers}

Reactor Engineering and various consultants agree that long term engine reliability and proper operation will be enhanced provided that qualified OEM spec parts are installed during repair actions, current upgraded procedures are followed, and pxesent performance monitoring continues. Future procurement of pistons, rods, rings, bushines, pins, bearings, and injectors wili be verified to OEM specs. Also, we should continue to follow current guidelines and rf:qui ements:

- pre-lubricate 3 minutes prior to planned starts

- maintain lower engine oil temps and correspond.ng

- higher lubricating oil pressures (45 psig min)

- utilize oil trand analysis for condition monitoring.

other commitments formulated upon completion of testing included:

1. Formalize trending programs for key engine data. Action ongoing in accordance with RED procedure RP 5.1401 rev 0 .

2. Increase frequency of $\mathrm{GM}$ heat exchanger inspection and cleaning $(I / C)$. Action complete, 12/91. WMS updated to schedule quarterly I/C. 
WSRC-TR-92-42-011

March 20, 1992

Page 19 of 20

Revision 0

3. Initiate and support fuel sampling program. Procedures complete.

4. Test and match fuel injection equipment. Injectors currently being sent to Norfolk, Virginia for test and certification. Fuel linkage and other equipment undergoing review to blueprint specifications. SRS test capability by latie 1992.

5. Reduce no-load testing, and increase loaded operations. Action at time of this memo is nearly complete. Revision 25 to Dpsol 105-1146-K, Monthly Suryeillance Testing, is complete. New yearly and quarterly load procedures are under development.

6. Complete parts replacement and $1200 \mathrm{kw}$ testing in L-Reactor. This action is currently on hold pending announcement of $\mathrm{L}-$ Reactor Restart strategy. Steps to procure qualified GM replacement parts has been initiated by Reactor Engineering and Reactor Maintenance. 
WSRC-TR-92-42-011

March 20, 1992

Page 20 of 20

Revision 0

\section{REFERENCES}

1. RTR 2469, M.E. Bacinoglu to G.F. Mertz, June 22, 1987, Bun-in_and Load Test of Upgraded and Bewound GM viesel Generater and Exciter - I Area.

2. WSRC-TR-90-42-132, M.E. Bacinoglu to F. Beranek, May 24, 1991, GM Diesed Generator Loading Capability With or Without the Design Basis Event $K=$ Area.

3. Inter-Office Memorandum, EPD-CWE-915088, Revision 2, K.P. Burrows and R.E. Gross to J.K. Chavis et al, March 20, 1991, Request for Inspection of GM Cleveland $16-278$ A parts (U).

4. SRS NCR, 91-NCR-06-097, 16-278A GM Connecting Reds, ARri1 12, 1921.

5. SRS NCR, 91-NCR-06-098, 16-278A GM Piston Rin Bushing, ARri1 12, 1221.

6. SRS NCR, 91-NCR-06-099, 16-278A_GM Pistens, Apri1 $12,1921$.

7. SRS NCR, 91-NCR-06-112, Cydinder Liners (GM 16-278A), Apri1 22, 1991.

8. Naval Sea Systems Command (NAVSEA) Technical Manual 0361-LP-160-9100, $1000 \mathrm{KW}$ Generator Set, Diesel Driven, Model 16-278A Diesel Engine cleveland Diesel Engine Division, GM Corp. August 1957.

9. US Nayy Maintenance Manual for Model 16-278A General Motors Diesel Engine with Detached pumps $1200 \mathrm{KW}, 1700$ bbo, Contract Number 345,412 , Cleveland Diesel Engine Division, GM Corporation, June 23, 1943.

10. Navy Department Bureau of Ships, NAVSHIPS 0341-350-9000, Supplement to Technical Manuals for Generad Motors Moded 278 and 278 D Diesel Engines, September 1963.

11. U.S. Navy Ships Technical Manual, NAVSEA S9086-HB-STM-000/CH-233, Chapter 233, Diesel Engines, December 1, 1979.

12. WSRC-TR-91-42-090, R.E. Gross to F. Beranek, Eactory Data Supperting GM Diesel eperabjitit, September 10, 1991 .

13. Temporary Operating Procedure, TOP-K-91-115, Test - GM \#1 Diesel Generaters with Iead Banks, May 14, 1991, Tom Hipp et al.

14. Temporary Operating Procedure, TOP-K-91-141, Test - GM 22 Diesel Generators with Lop:inins, May 29, 1991, Tom Hipp et al.

15. Maintenance Manual for Cleveland Diesel Engines, BPF 202248, Cleveland Diesel Engine Division, General Motors Corporation, 1953.

16. RRD-RSE-910573, H.D. Kane to B.D. Getson, April 26, 1991, Lube Qil choice for 108 Building GM Gleveland Engines. 
TABLE 1

Wrist Pin Geometric Characterization

\begin{tabular}{|c|c|c|c|c|}
\hline $\begin{array}{c}\text { Pin } \\
\text { Ideentification } \\
\end{array}$ & $\begin{array}{l}\text { surface Fin. } \\
\text { (R, pinches) }\end{array}$ & 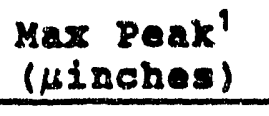 & $\begin{array}{c}\text { Out-of-Round } \\
\text { (inches) }\end{array}$ & 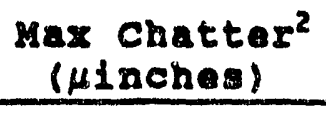 \\
\hline $\begin{array}{l}\# 1 R \\
\text { (used) }\end{array}$ & 7 & 65 & 0.000021 & 22 \\
\hline $\begin{array}{l}\text { \#2R } \\
\text { (used) } \\
\end{array}$ & 3 & 18 & 0.000030 & 15 \\
\hline $\begin{array}{l}\# 5 \mathrm{~L} \\
\text { (used) }\end{array}$ & 8 & 31 & 0.000110 & $200^{3}$ \\
\hline $\begin{array}{l}\text { \#I } \\
\text { (used) } \\
\end{array}$ & 3 & 18 & 0.000023 & 15 \\
\hline $\begin{array}{l}\text { \#11R } \\
\text { (used) }\end{array}$ & 5 & 28 & 0.000050 & 50 \\
\hline $\begin{array}{l}\text { Hatch \& Kirk } \\
\text { (new) }\end{array}$ & $7-9$ & 31 & -- & -- \\
\hline $\begin{array}{l}\text { Japan } \\
\text { (new) }\end{array}$ & $\leq 2^{6}$ & 11 & -- & $-\infty$ \\
\hline $\begin{array}{l}\text { Repolished } \\
\text { (used) }\end{array}$ & $<2^{4}$ & 5 & -- & -- \\
\hline $\begin{array}{l}\# 108-1 P, C y 1 . \# 1 \\
\text { (used) }\end{array}$ & 3 & 10 & -- & -- \\
\hline $\begin{array}{l}\text { A } \\
\text { (used) }\end{array}$ & $5-7$ & 26 & -- & -- \\
\hline $\begin{array}{l}\text { B } \\
\text { (used) }\end{array}$ & $6-8$ & 35 & - & -- \\
\hline 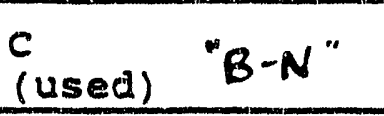 & $2^{4}$ & 11 & - & - \\
\hline${ }_{\text {(used) }}^{D} B-N$ " & $2^{4}-3$ & 12 & -- & -- \\
\hline
\end{tabular}

1. Distance from mean line to Bighest peak measured in profile trace(s) taken.

2. Peak to valley distance, the normal method of specifying chatter.

3. One deviation only; may be a scratch. Next largest chatter 20 minches.

4. $R_{\text {. }}$ of 2 is lowest value faAA's equipment can read. 


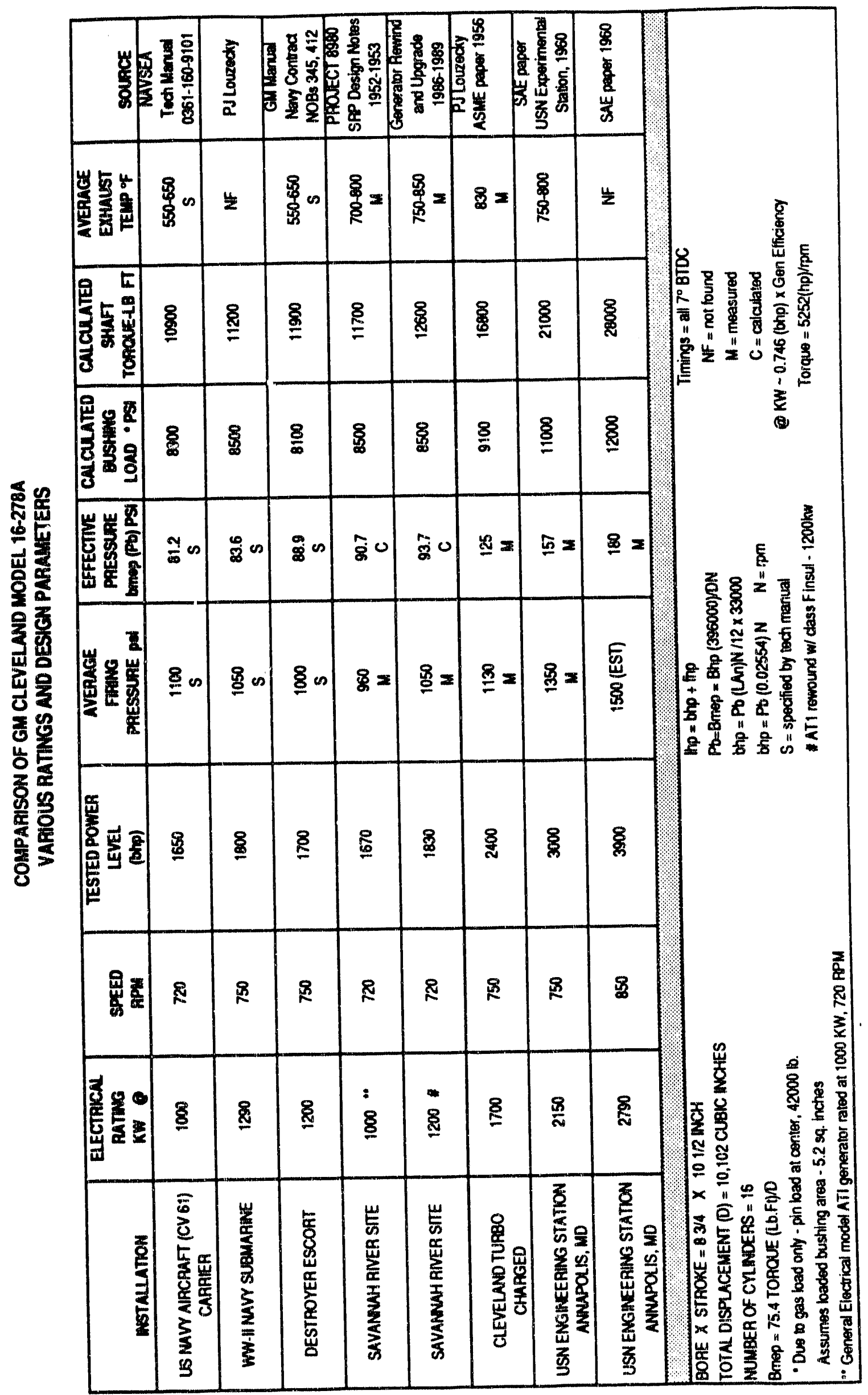

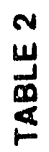




\section{GM D/G DATA COLLECTION}

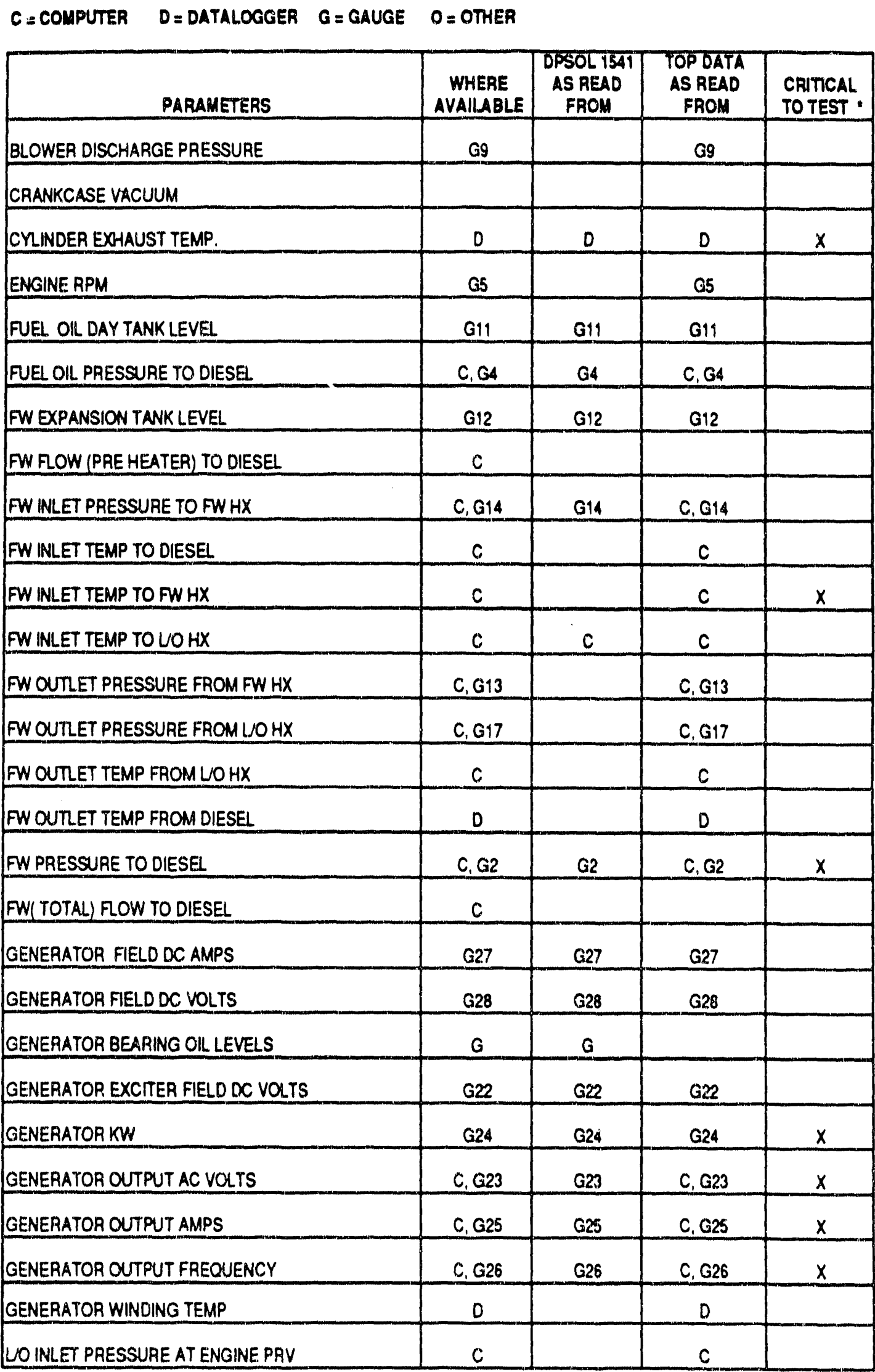




\section{GM D/G DATA COLLECTION}

\begin{tabular}{|c|c|c|c|c|}
\hline$D=$ DATALCGGER $G=$ GAUGE & $0=$ OTHER & & & \\
\hline PARAMETEAS & $\begin{array}{c}\text { WHEAE } \\
\text { AVAILABLE }\end{array}$ & $\begin{array}{l}\text { DPSOL 15A1 } \\
\text { AS READ } \\
\text { FROM }\end{array}$ & $\begin{array}{c}\text { TOPDATA } \\
\text { AS READ } \\
\text { FROM }\end{array}$ & $\begin{array}{l}\text { CRITICAL. } \\
\text { TO TEST }\end{array}$ \\
\hline LO OUTLET PRESSURE FROM UO HX & C.G16 & & C. G16 & \\
\hline LO ENGINE INLET TEMP & C & & $\mathrm{C}$ & \\
\hline LO ENGINE OUTLET TEMP. & C & & C & $x$ \\
\hline LO FLOW TO DIESEL & C & & & \\
\hline LO FULL FLOW FILTER INLET PRESSURE & G18 & G18 & G18 & \\
\hline LO FULL FLOW FILTER OUTLET PRESSURE & G19 & G19 & G19 & \\
\hline LO INLET TEMP. TO NO HX & C & & c & \\
\hline LO PRESSURE AT BLOWER END & C.G6 & & C, G6 & \\
\hline LO PAESSURE TO DIESEL & C. G3 & G3 & C. G3 & $x$ \\
\hline LO PUMP DISCHARGE PRESSURE & $C_{1}, G_{20}$ & & C. G20 & \\
\hline LO SAMPLE ANALYSIS & 0 & & SEE NOTE 3 & \\
\hline LO SUMP TANK LEVEL & G21 & G21 & G21 & \\
\hline OVERSPEED GOV. OILLEVEL & G10 & G10 & G10 & \\
\hline PREHEATER PUMP OIL CUP LEVEL & G & G & & \\
\hline BW FLOW TO DIESEL & C & & & \\
\hline RW HEADER INLET TEMP & C & & $c$ & \\
\hline RW HEADER PRV INLET PRESSURE & C. G7 & G7 & C.G7 & \\
\hline RW HEADER PRV OUTLET PRESSURE & C. G8 & G8 & C. G8 & \\
\hline RW INLET TEMP. TO FW HX & C & & C & \\
\hline RW OUTLET PRESSURE FROM FW HX & C. G15 & & C. G15 & \\
\hline RW OUTLET TEMP. FROM FW HX & C & & c & \\
\hline RW PRESSURE TO DIESEL & C. G1 & G1 & C. G1 & $x$ \\
\hline \multicolumn{5}{|c|}{$\begin{array}{l}\text { NOHES } \\
\text { 1) HAND HELD INFARED THERMOMETER CAN BE USED AS A BACKUP TO ANY TEMPERATUAE READOUT } \\
\text { EXCEPT CYLINDEP. EXYHAUST TEMPERATURE. } \\
\text { 2) GENERATOR KW CAN BE CALCULATED USING VOLTS \& AMPS IF KW METER BECOMES INOPERATIVE. LOAD } \\
\text { BANK KW METERS ARE ALSO AVAILABLE. } \\
\text { 3) LUBE OIL SAMPLE ANALYSIS DATA RECORDED ON ANALYSIS LAB REPORT. }\end{array}$} \\
\hline
\end{tabular}

TABLE 3 


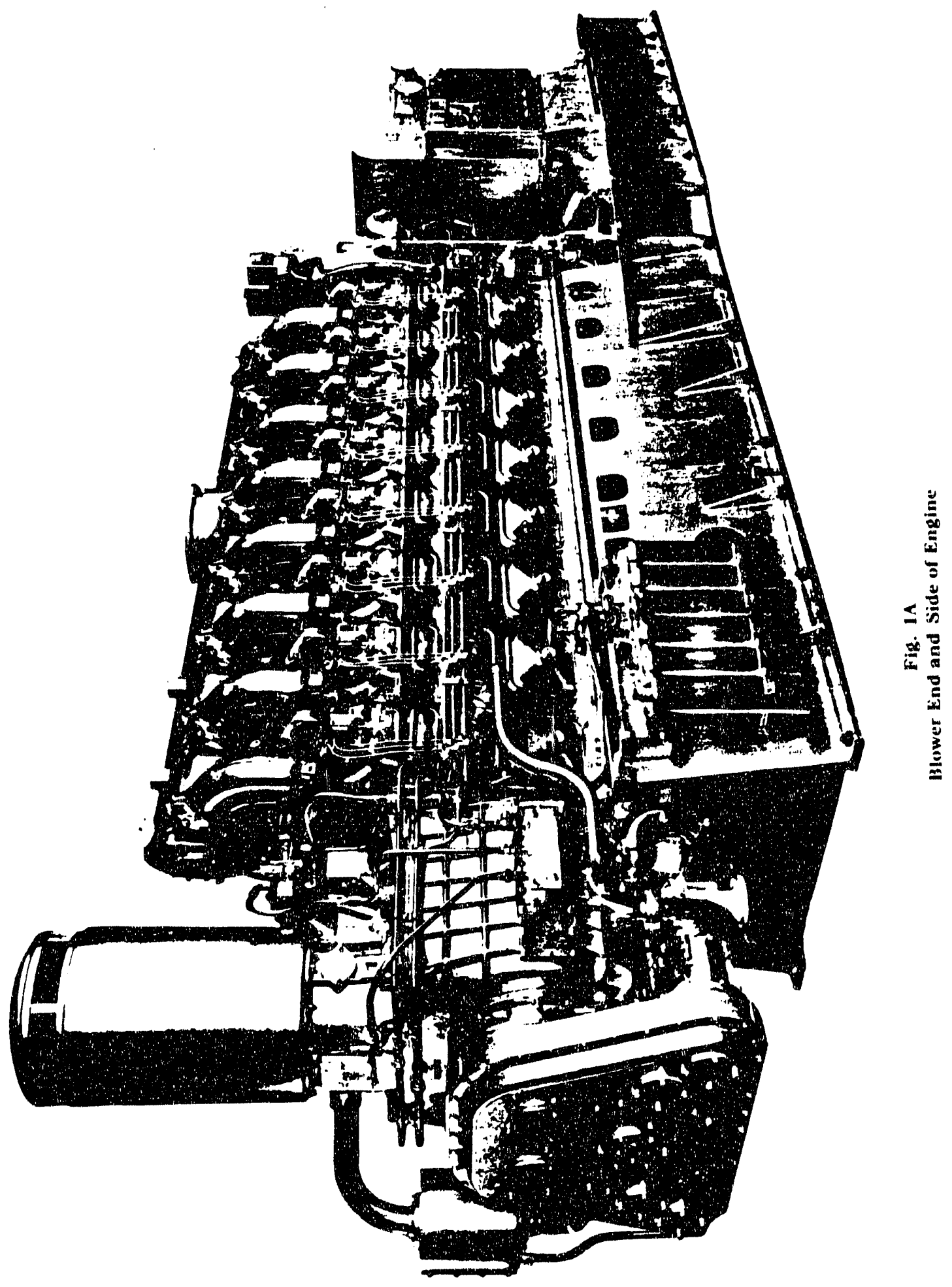

A.2

FIGURE IA 
MODEL 278A DIESEL ENGINE

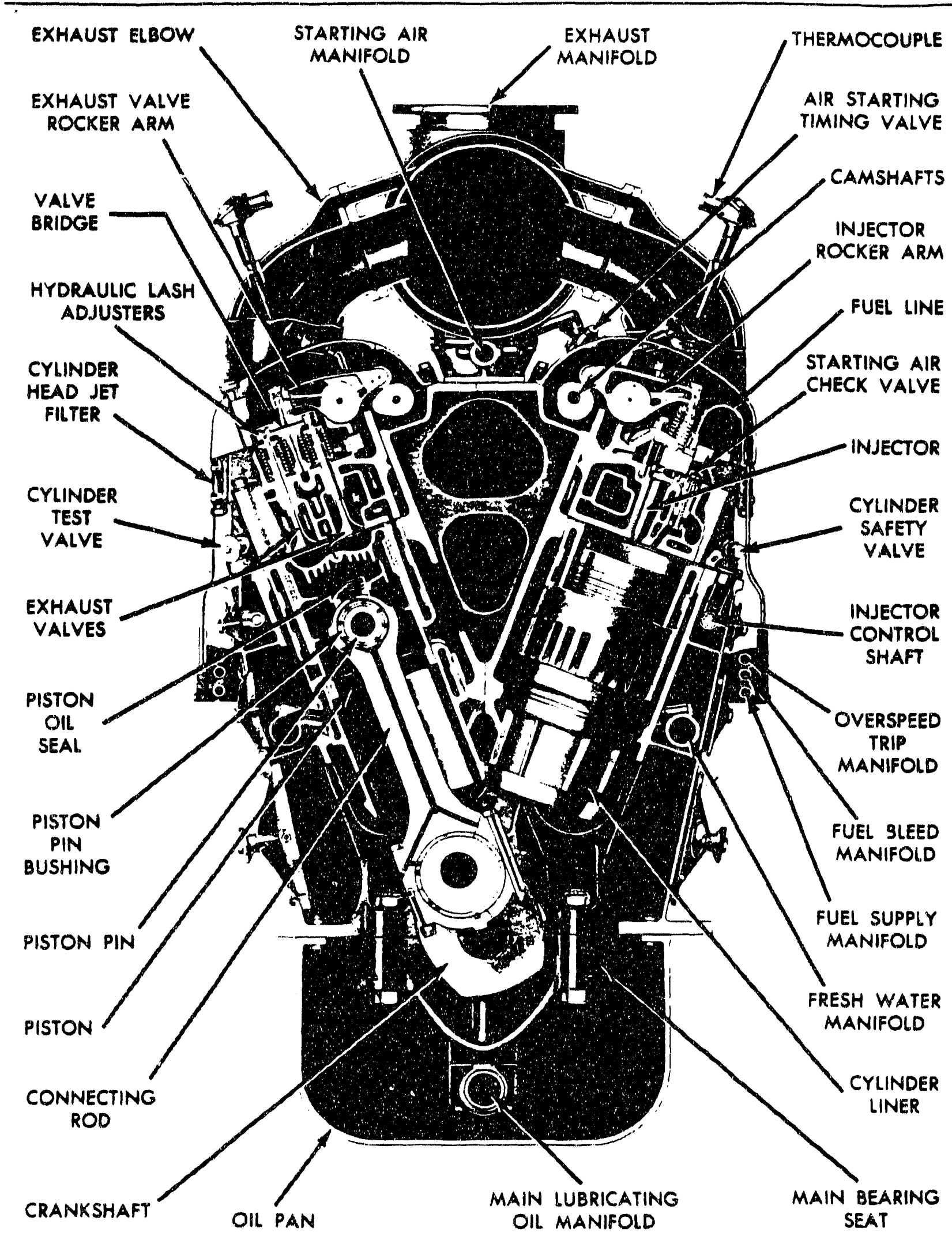

Fir. 3A

Cross Section of .ilodel 278A Engine

A.4 


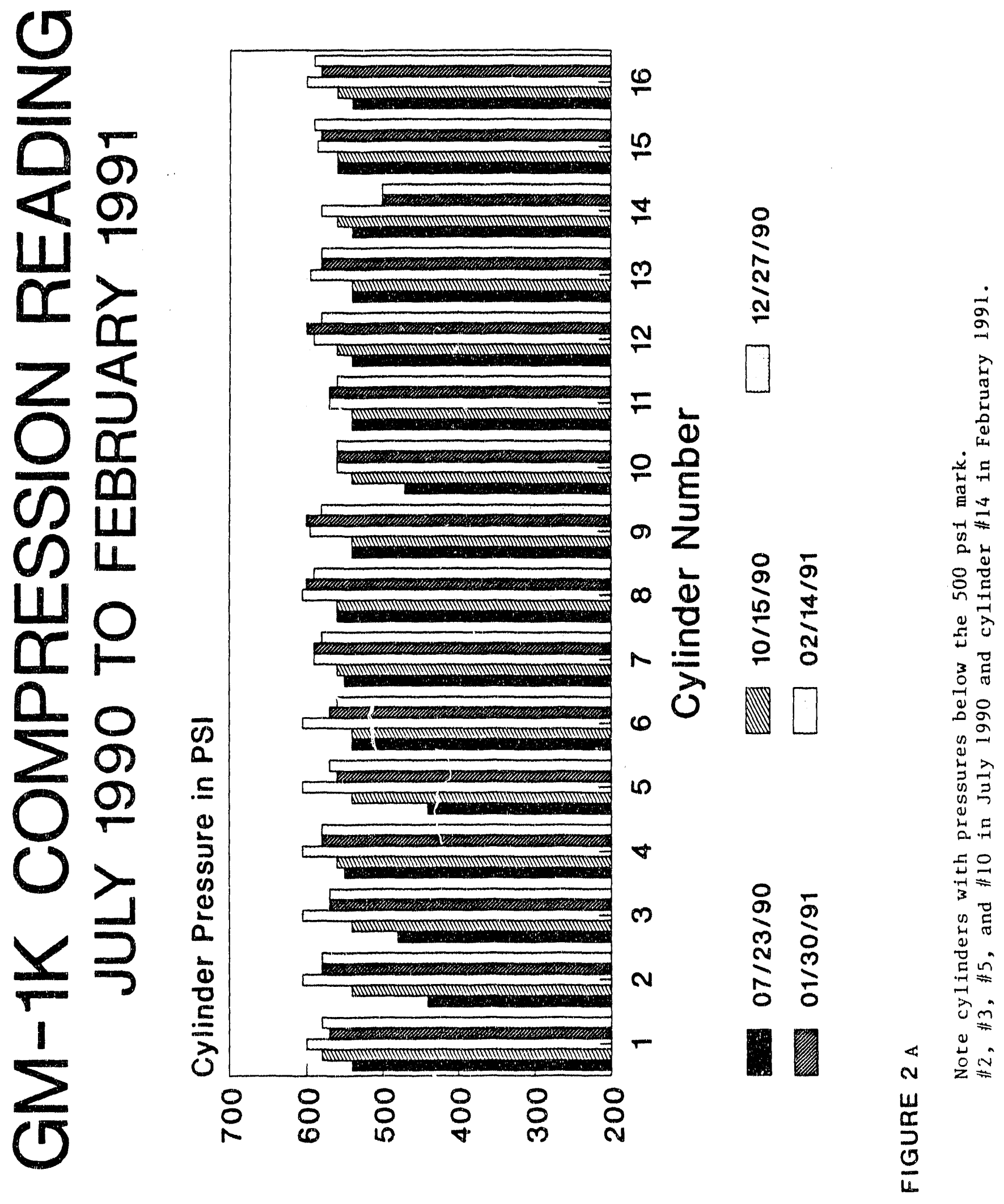




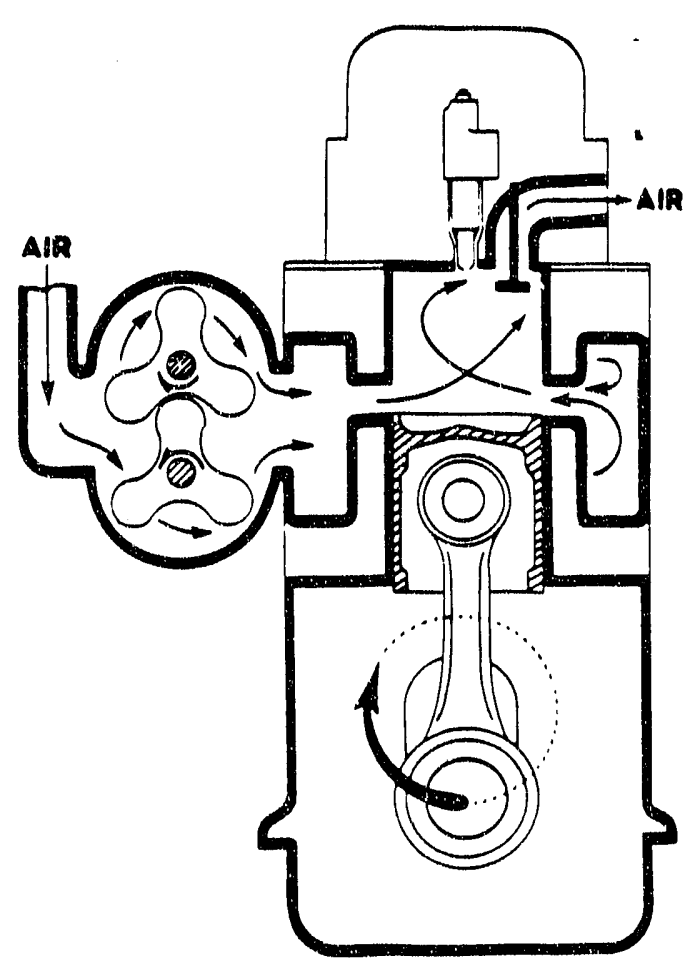

Engine scavenging. Air ports and exhaust valves are open.

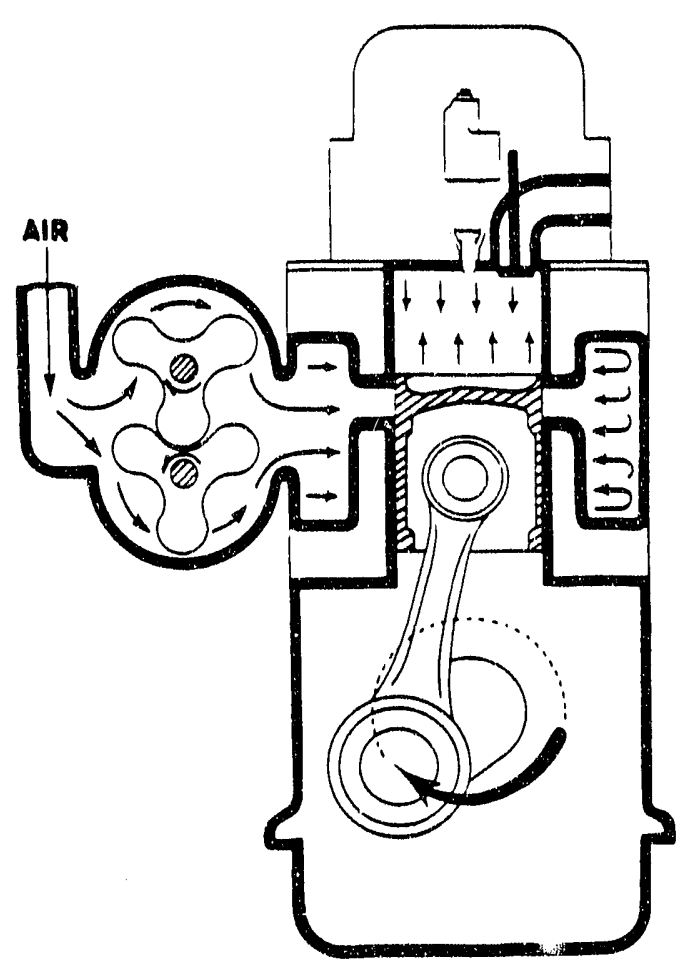

Air ports and exhaust valves closed-on compression stroke.

MODEL 278A DIESEL ENGINE

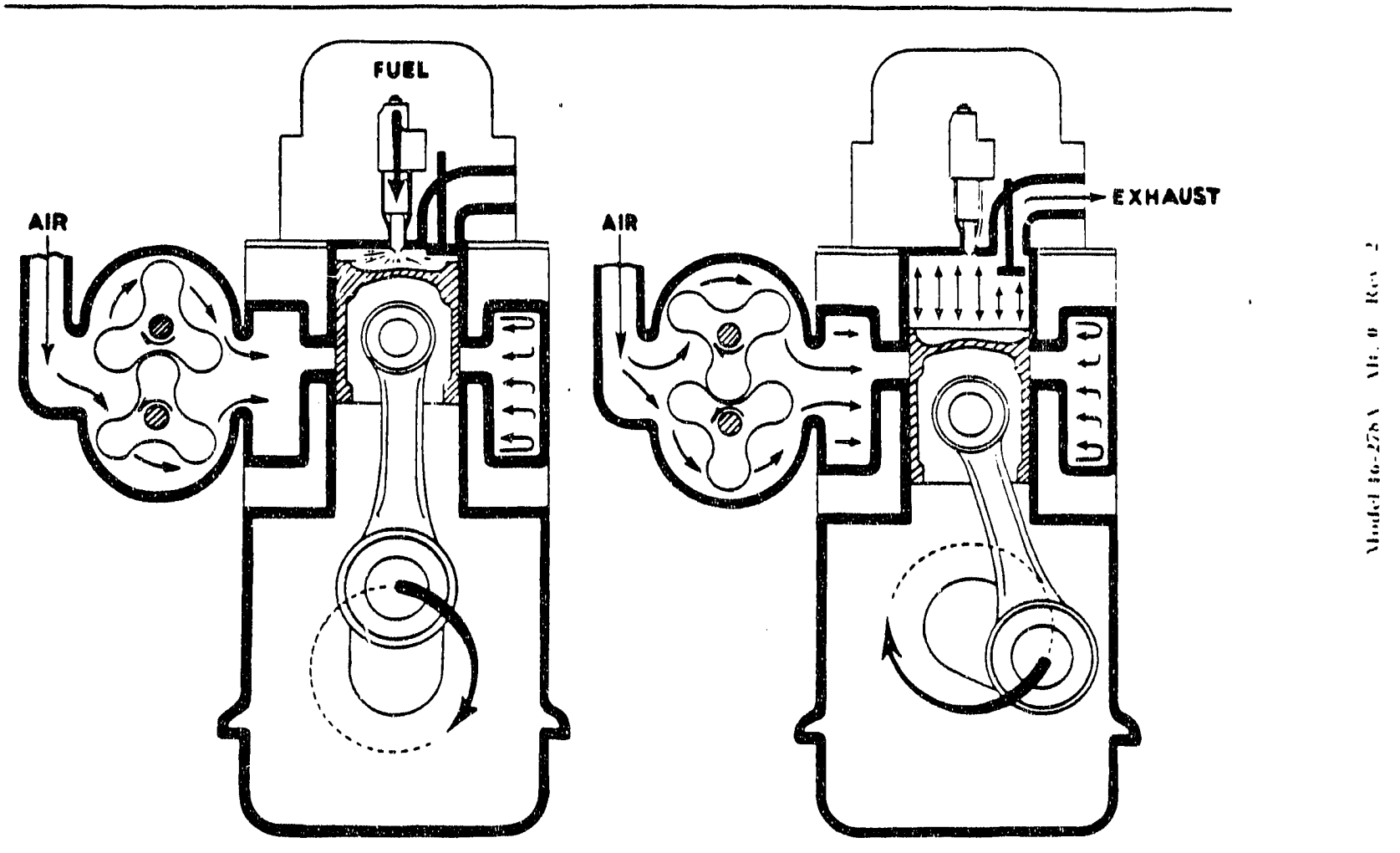

Injector is injecting fuel. Just prior to that, compression is at maximum.
Cylinder is beginning to exhaust after power is developed. 

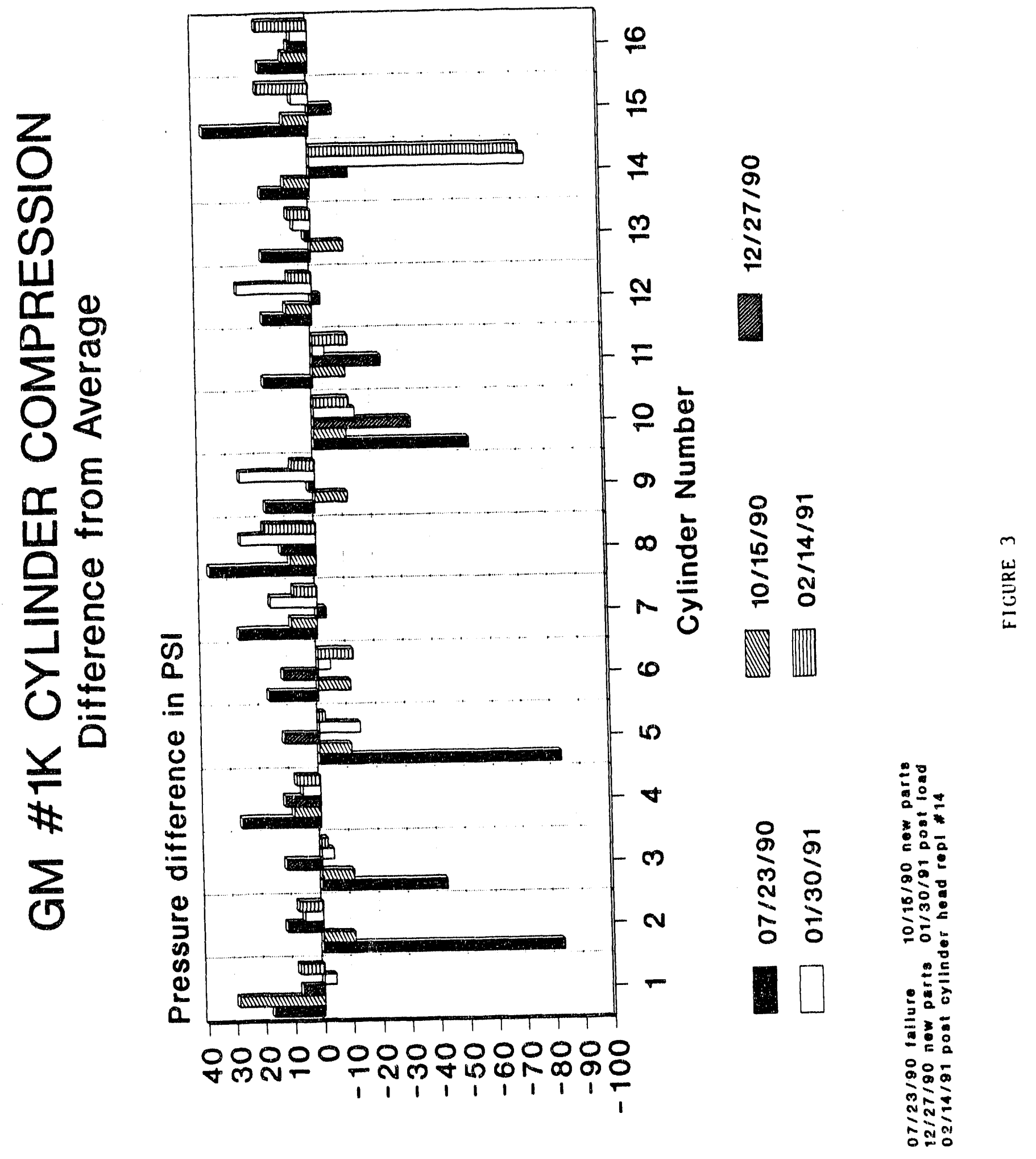


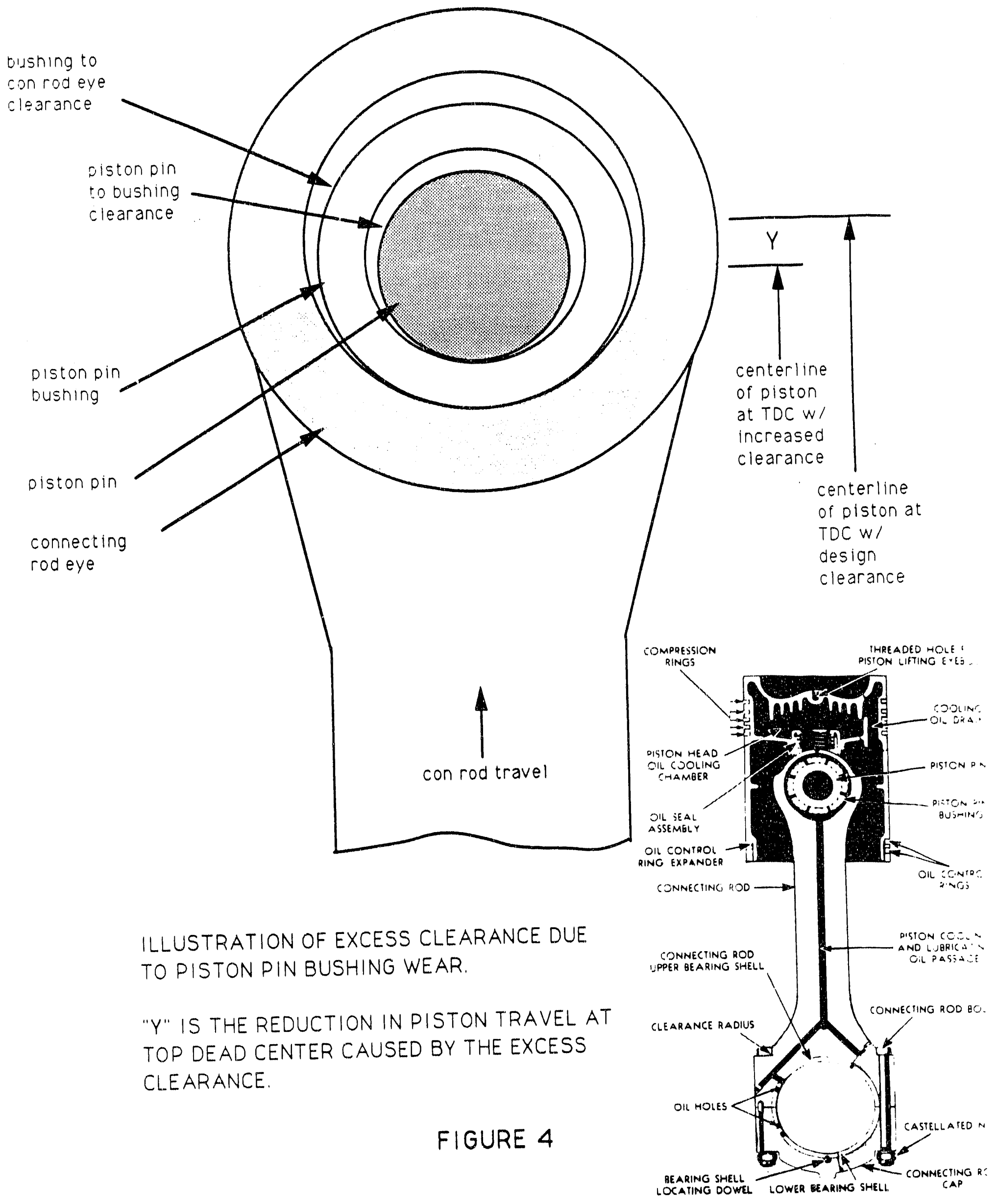

Fig. 3H

Piaton und Connecting Rod Assembly 


\section{Wrist Pin Surface Profiles}

\section{PIN 7ZL: $R_{a}=3$ HINCHES}

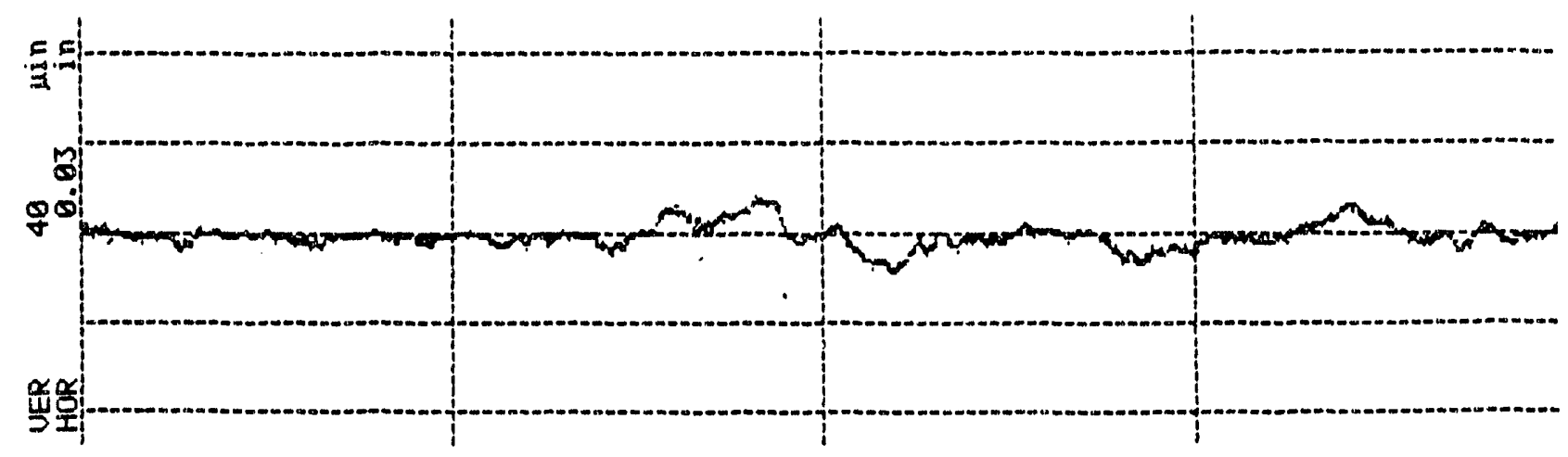

PIN 11R: $R_{a}=5$ HINCHES

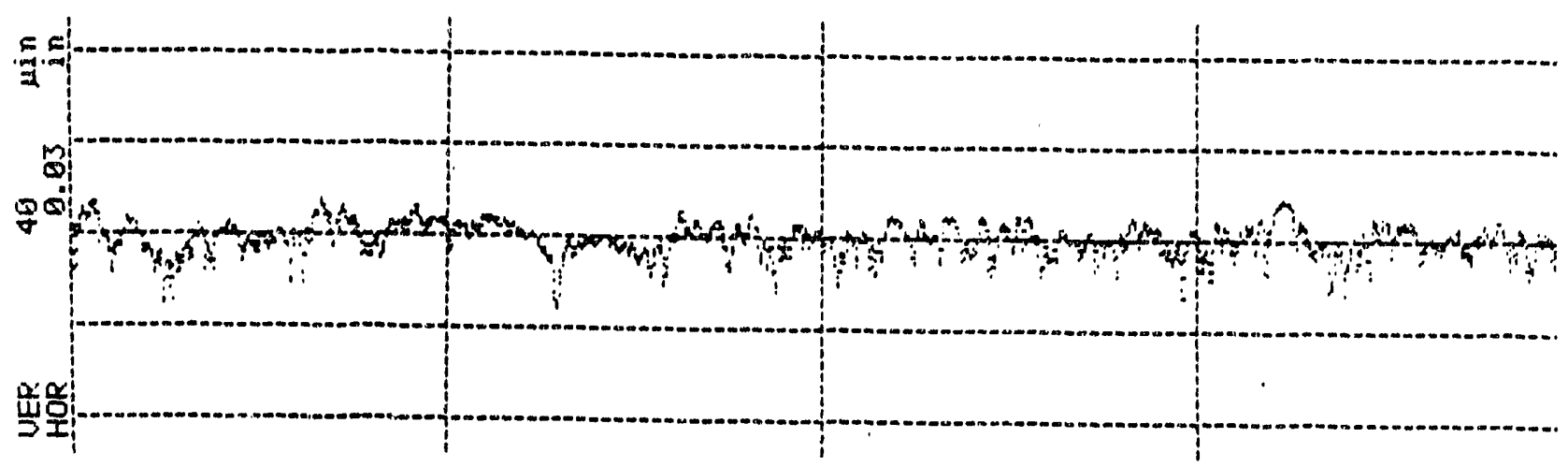

Figure 5 


\section{Wrist Pin Surface Profiles}

\section{BIN IIR: $R_{0}=7$ HINCHES}

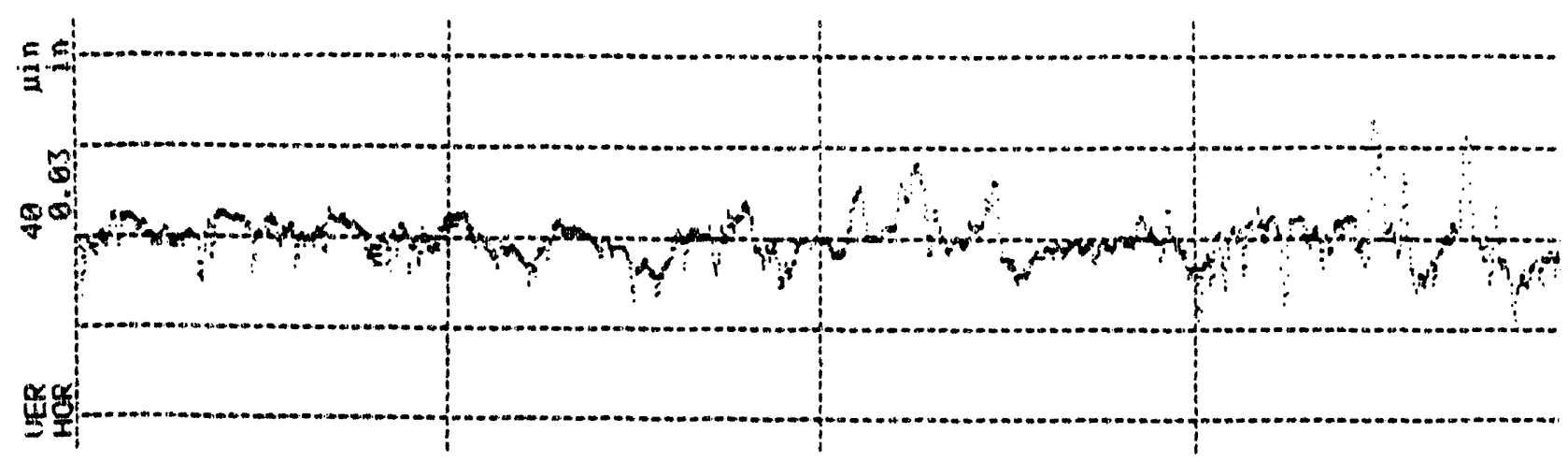

\section{PEN 12R: $R_{B}=3$ HINCHES}

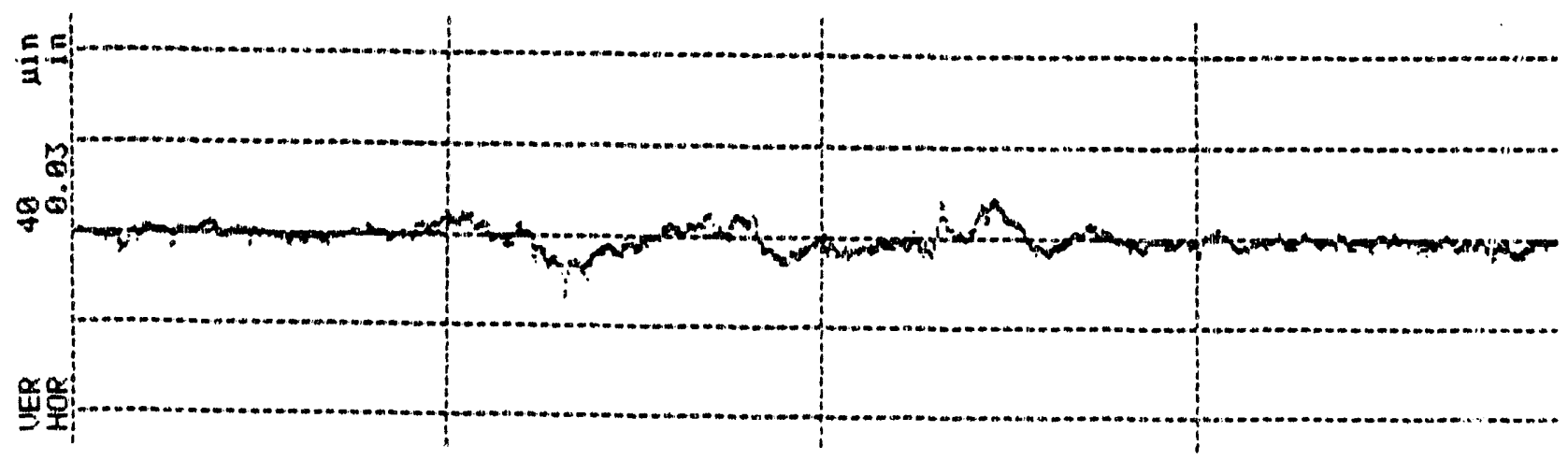

\section{PIN 5L: $R_{0}=8$ HINCHES}

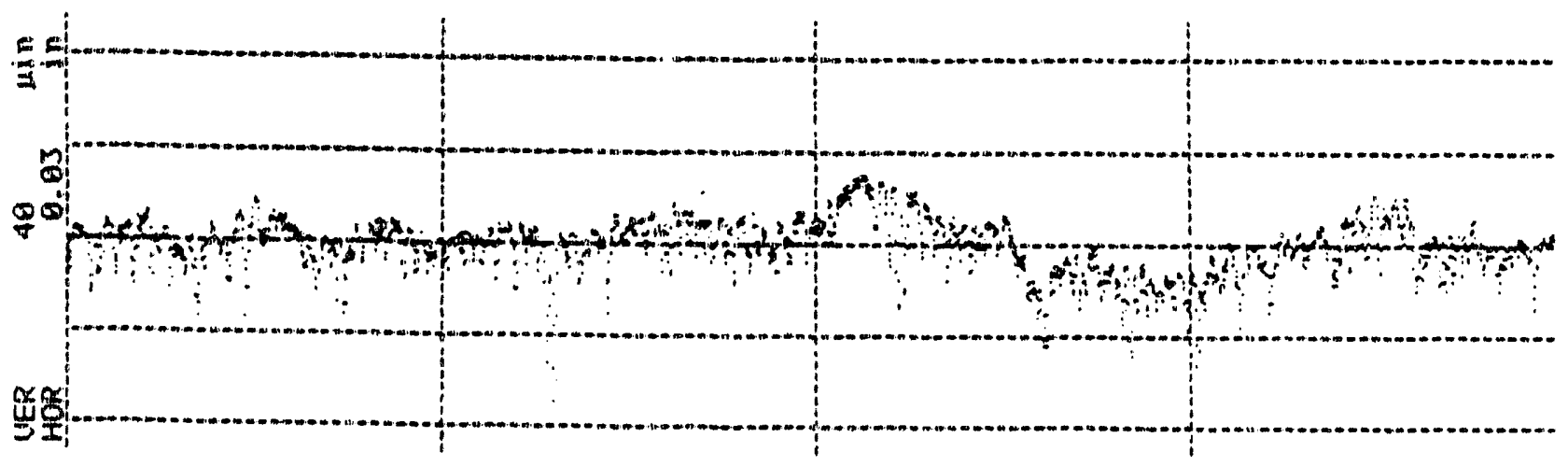


Wrist Pin Surface Profiles

NEW HATCH \& KIRK PIN

(SIMILAR TO PINS USED IN REBUILDS)

LOCATION 1: $R_{a}=9$ pINCHES

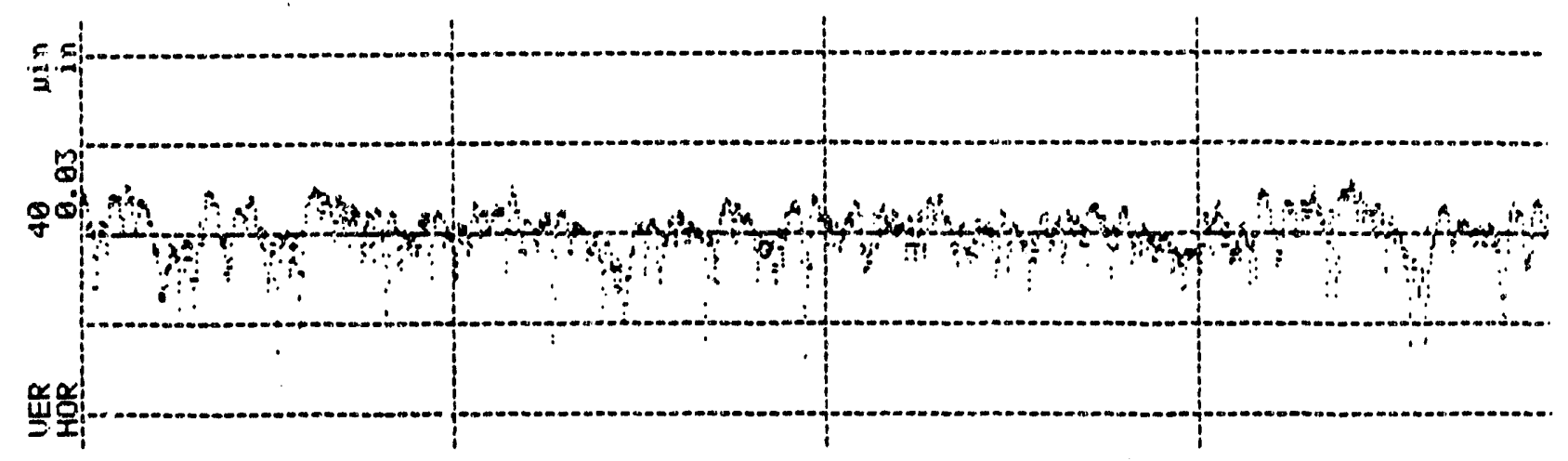

LOCATION 2: $R_{0}=7$ H INCHES

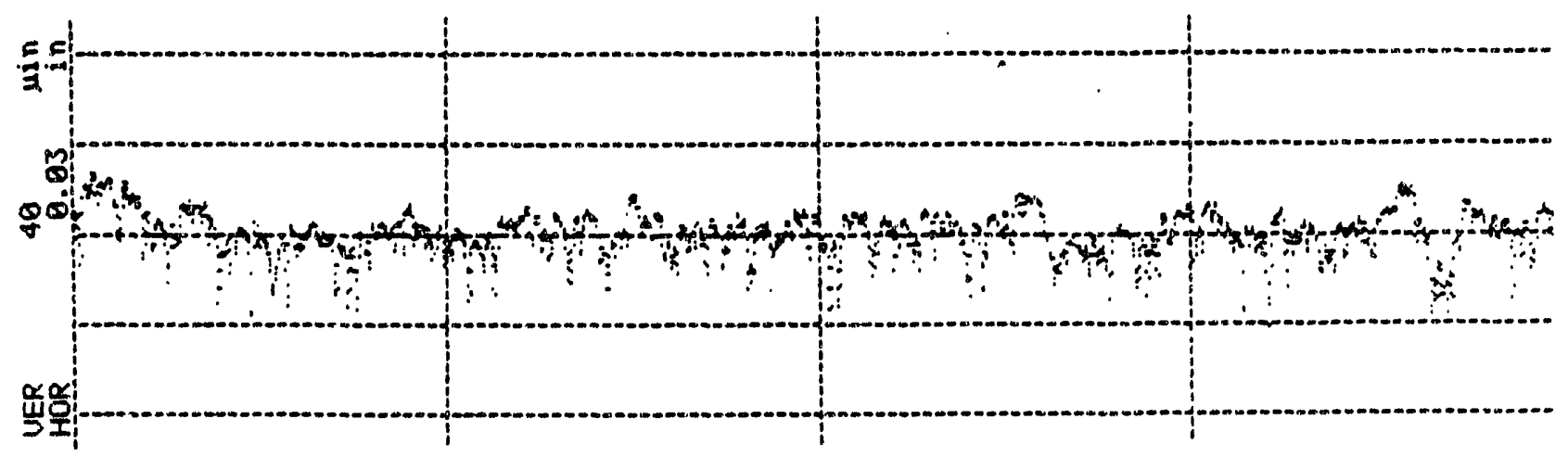

LOCATION 3: $R_{8}=8$ INCHES

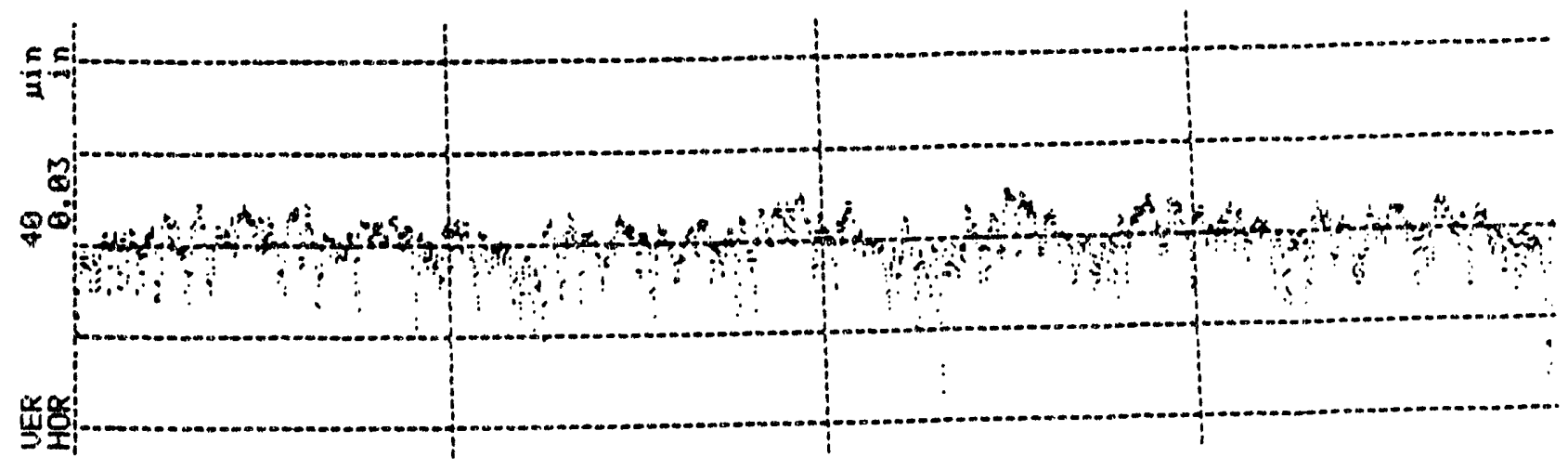

FIGURE ? 


\section{Wrist Pin Surface Profiles}

\section{\#108-1P (BN): $R_{Q}=3$ HINCHES}

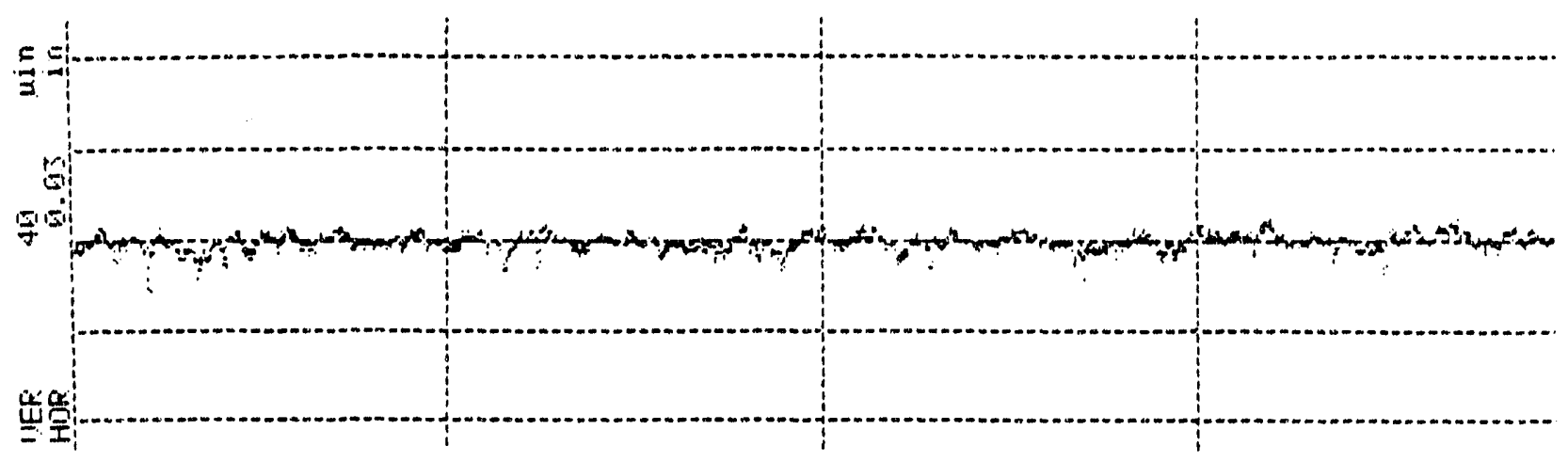

\section{HATCH \& KIRK PIN (JAPAN): $R_{0} \leq 2$ HINCHES}

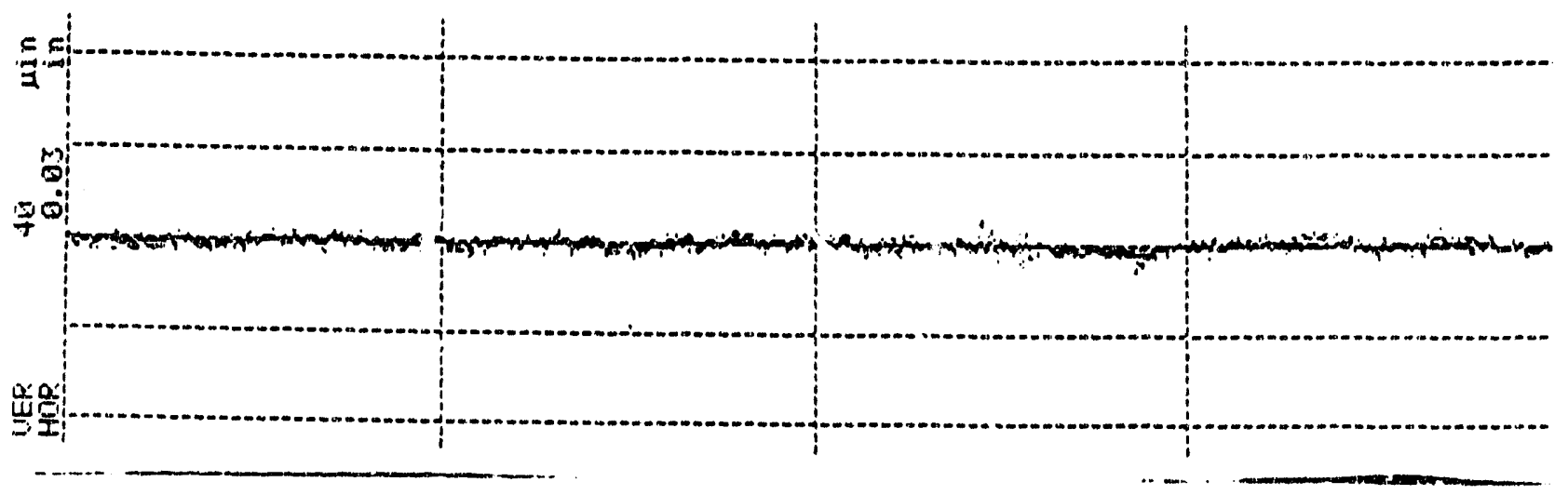

USED PIN REPOLISHED AT SAVANMAH RIVER: R, $\leq 2$ HINCHES

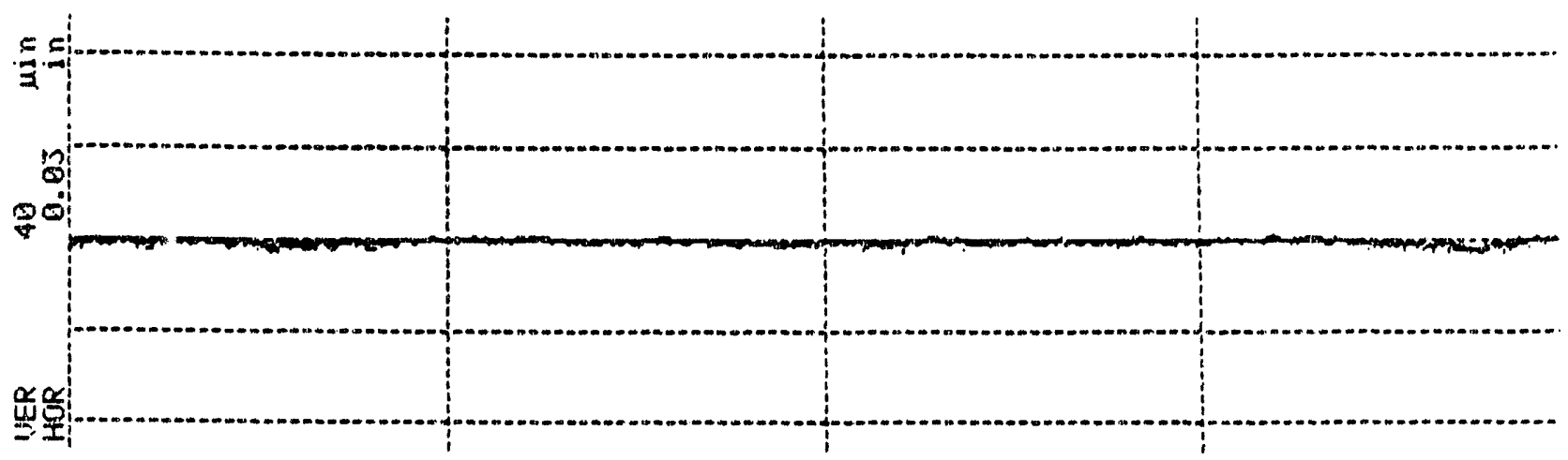

FIGURE 8 


\section{Wrist Pin Surface Profiles}

\section{PIN "A"}

\section{Center: $R_{\mathrm{a}}=5$ HInches}

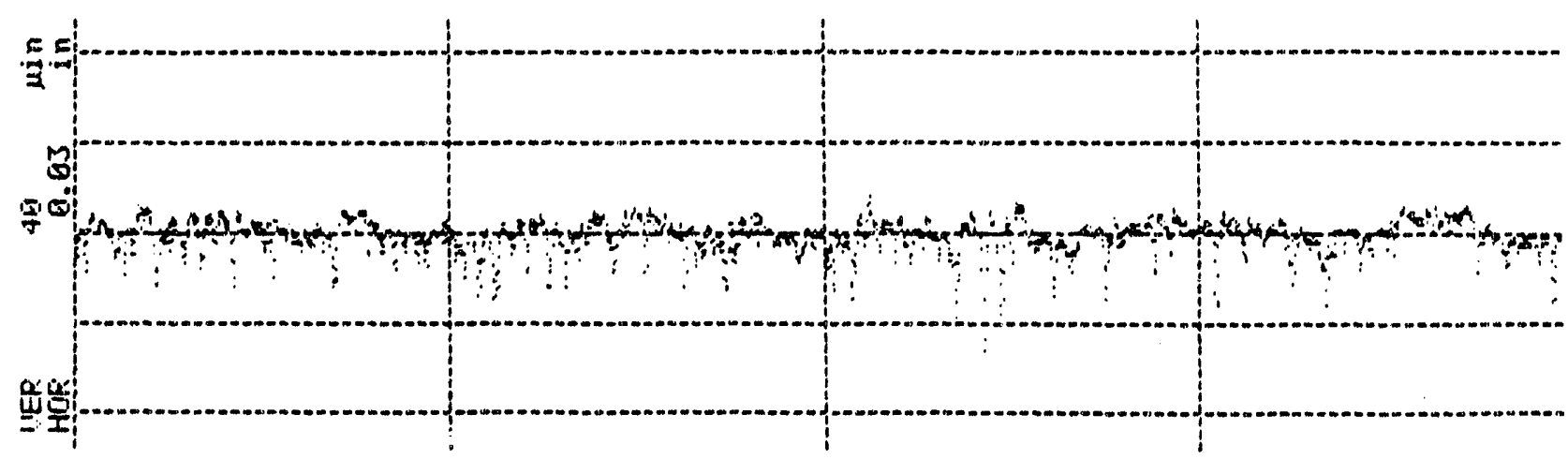

\section{ENR: $R_{0}=7$ HINCHES}

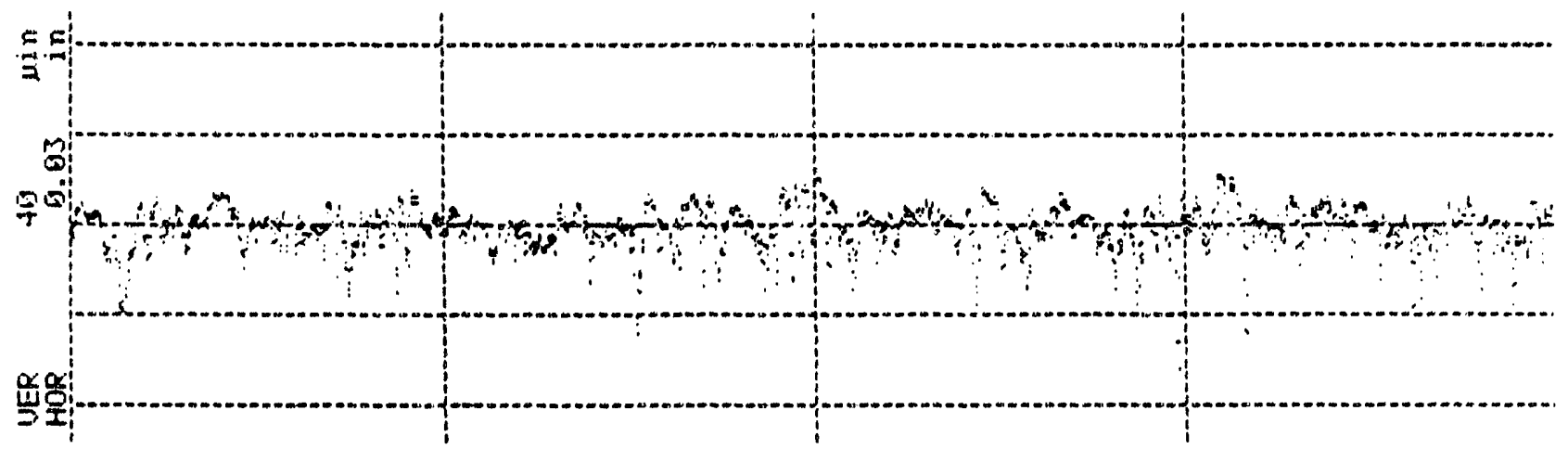




\section{Wrist Pin Surface Profiles}

\section{PIN "B"}

\section{CENTER: $R_{0}=8$ HINCHES}

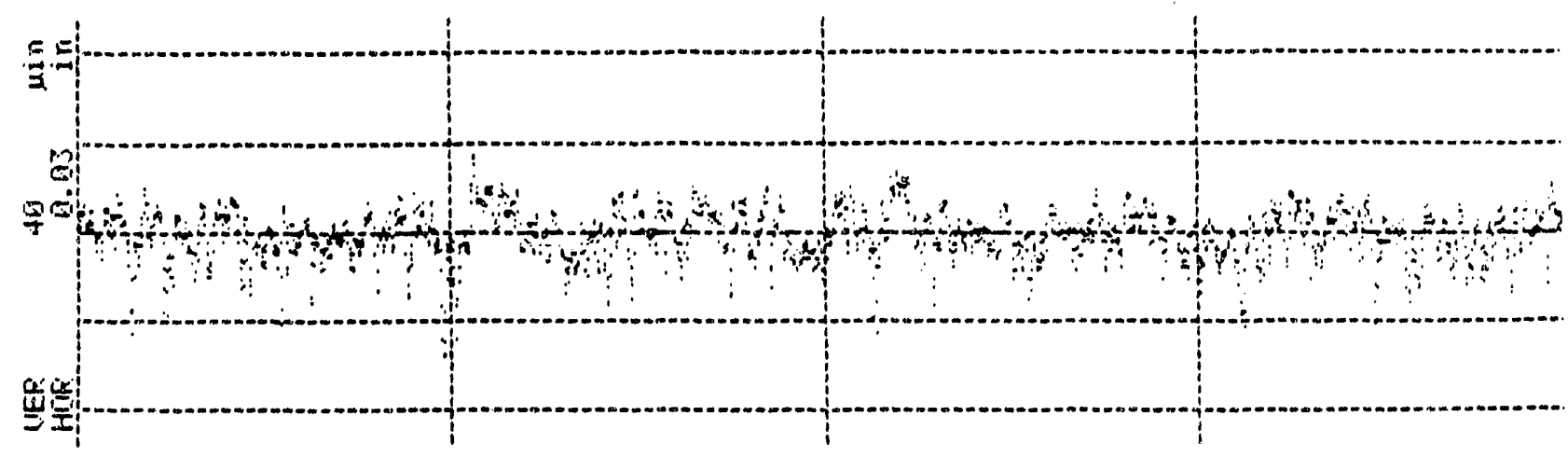

\section{ENR: $R_{a}=6$ HINCHES}

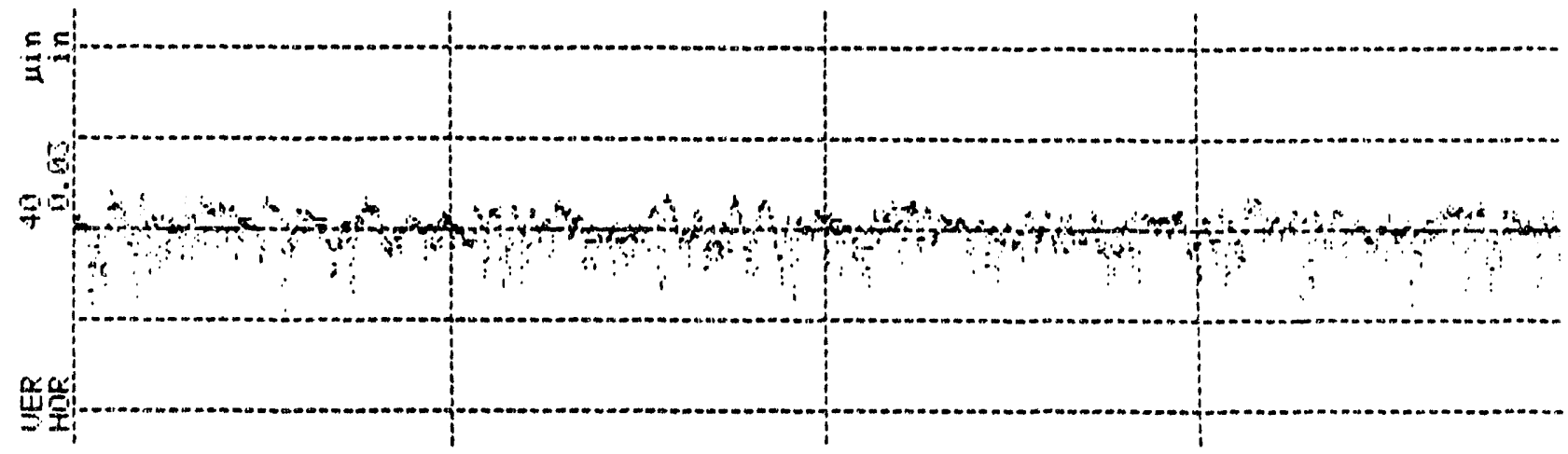

FIGURE 10 


\section{Wrist Pin Surface Profiles}

\section{PIN "C" (BN)-CENTER (END IS SIMILAR): $R_{\mathrm{a}}=2$ HINCHES}

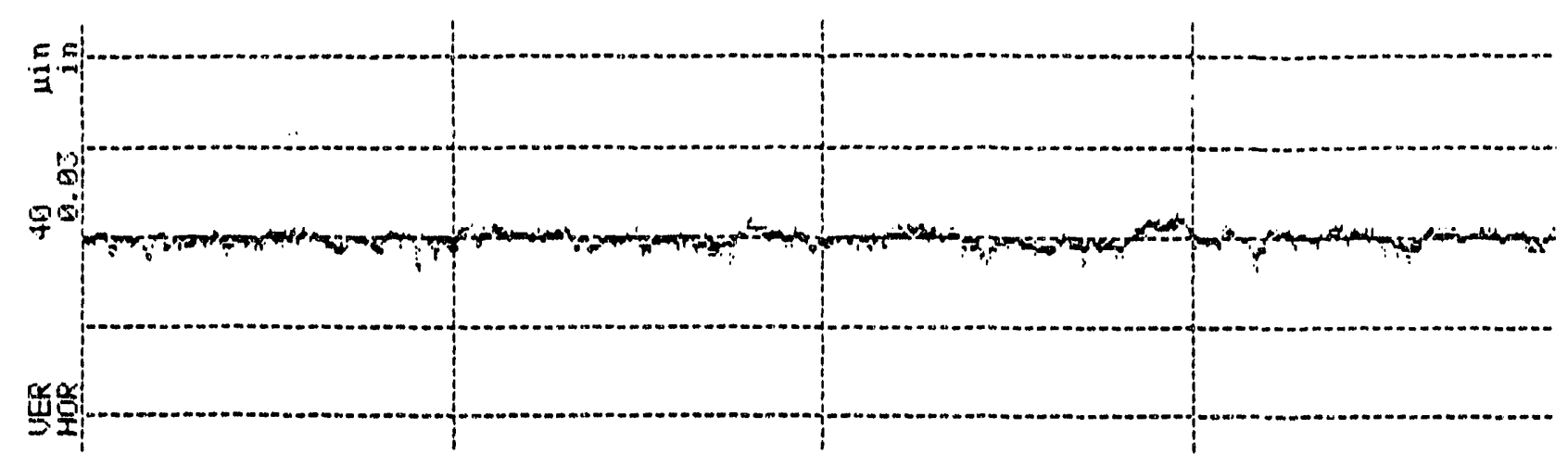

PIH "O" (BN)-CENTEB: $R_{a}=2$ HINCHES

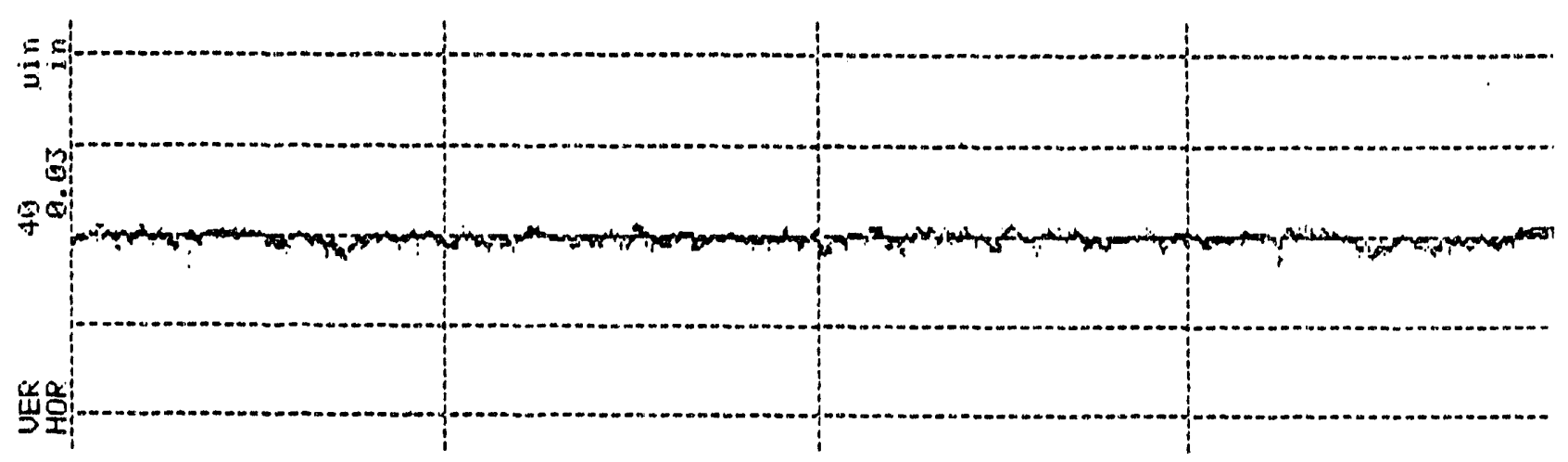

\section{PIN "D" (BN) -END: $R_{a}=3$ HINCHES}

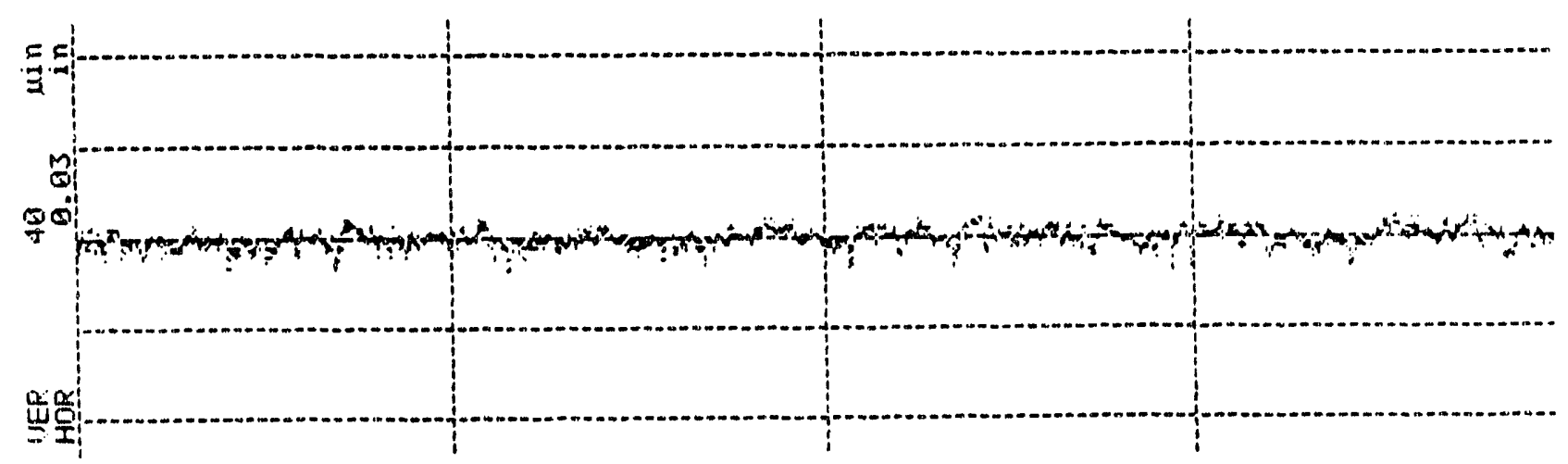

Figure 11 


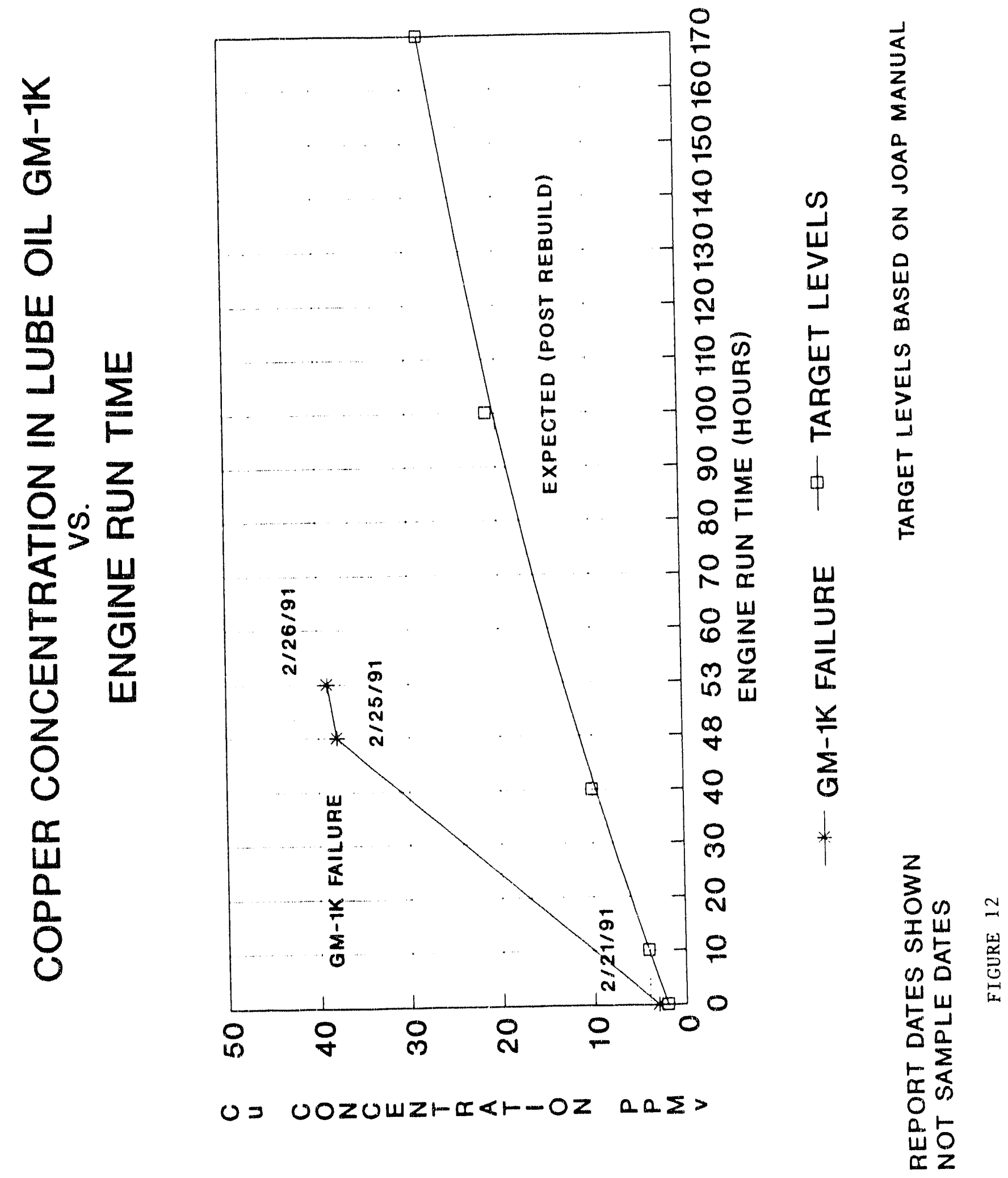




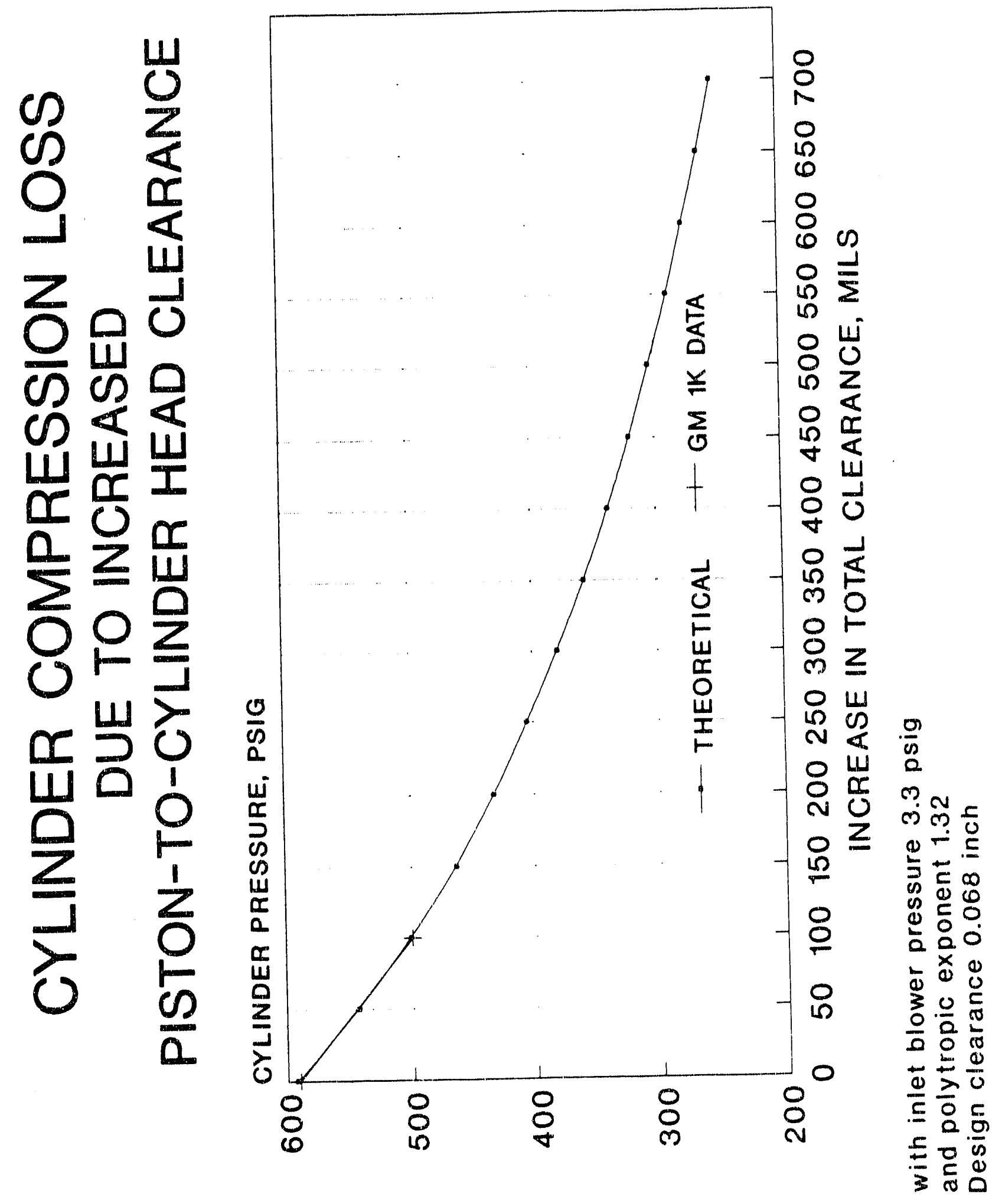




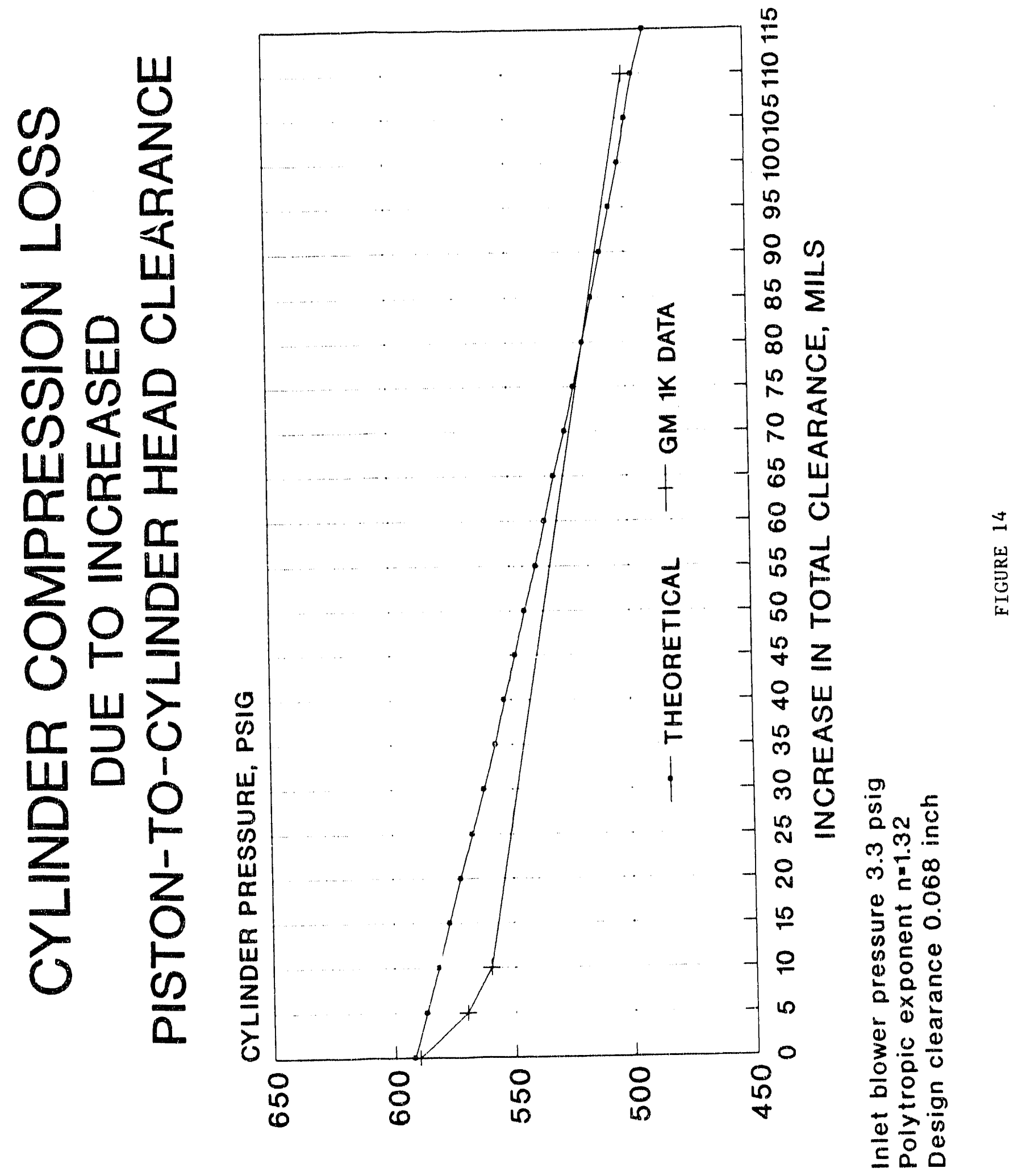




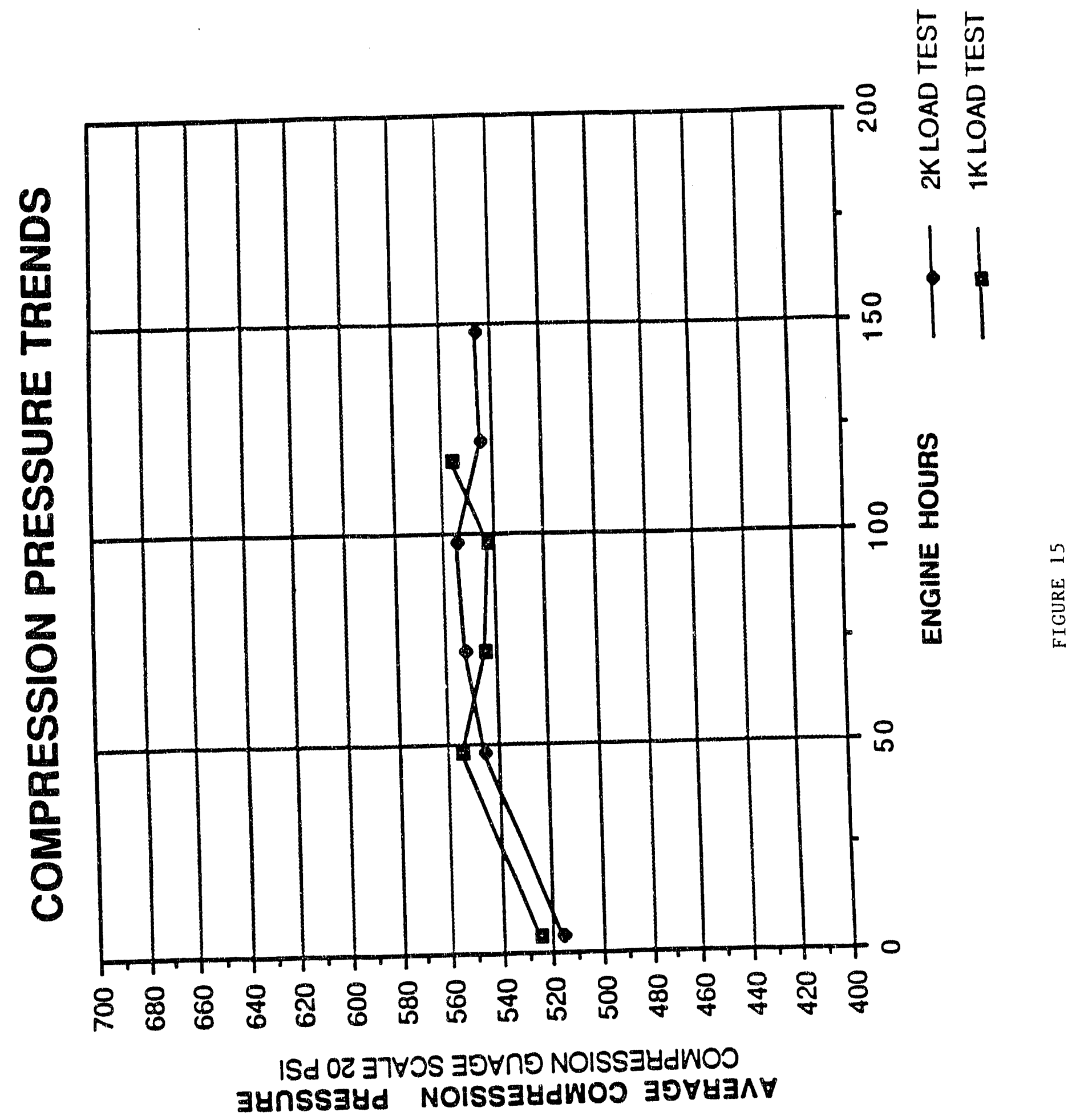



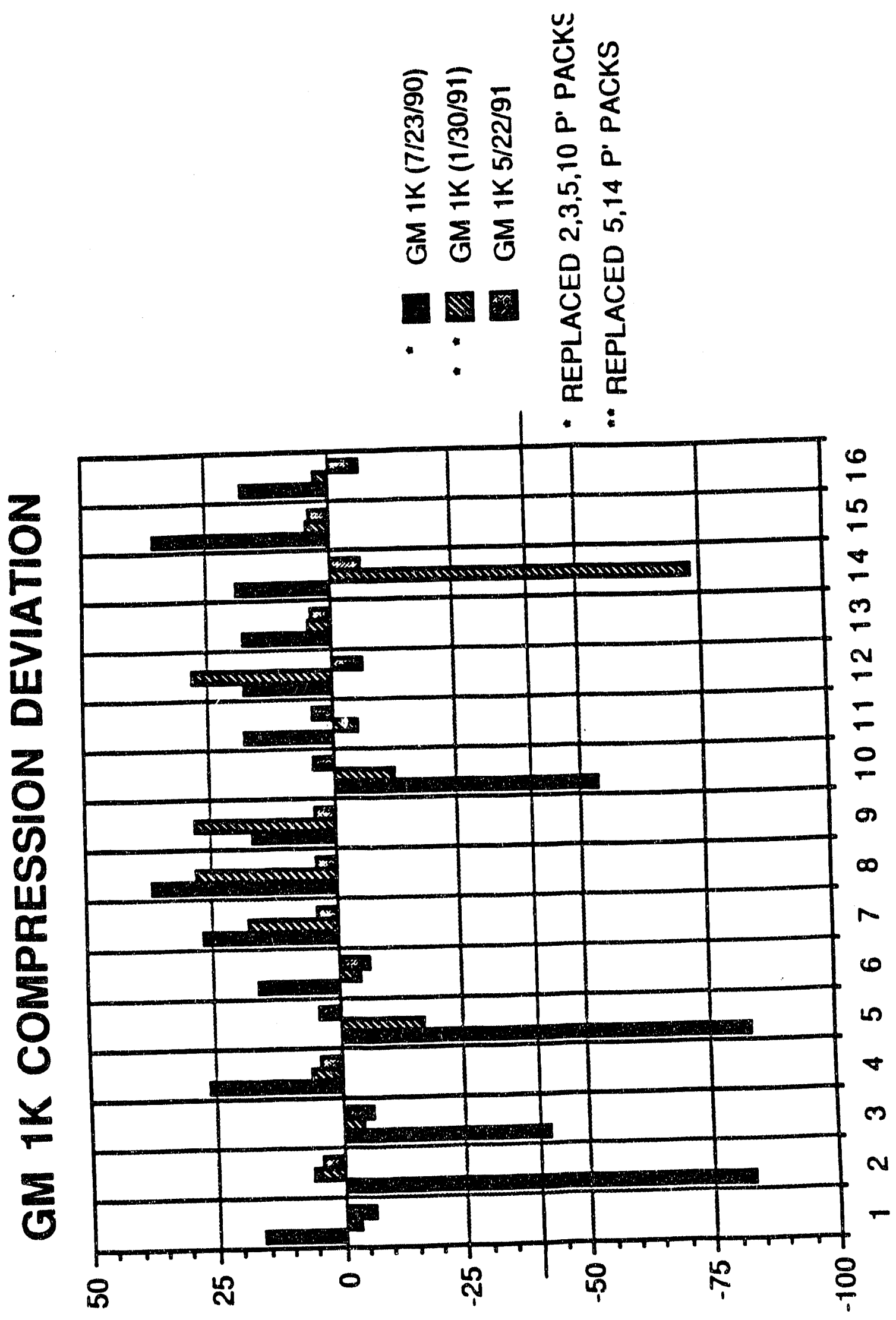

$\underset{2}{2}$

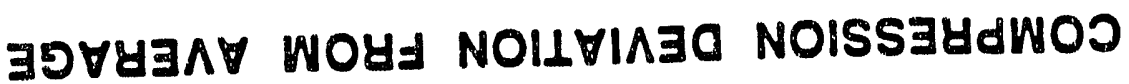




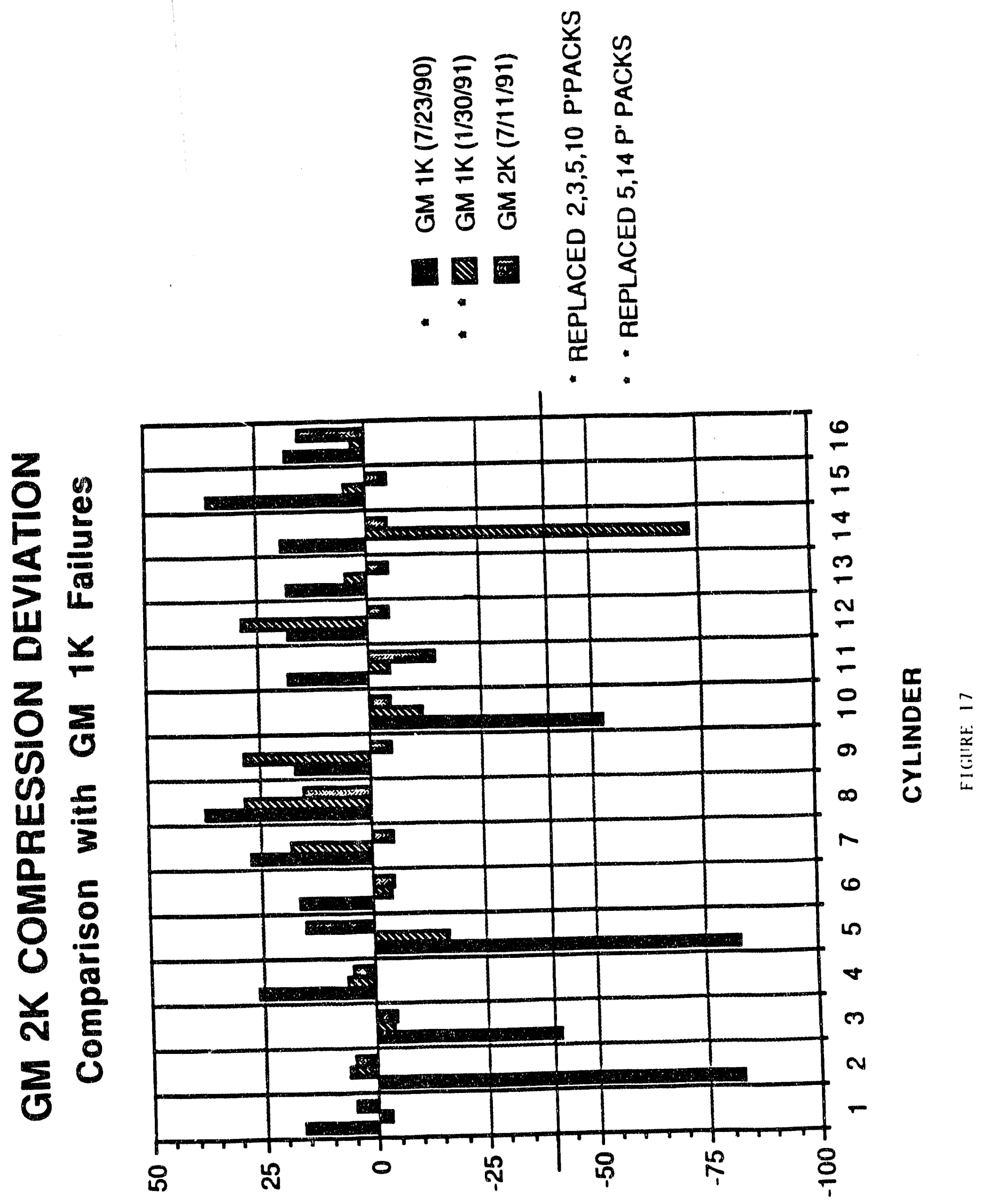

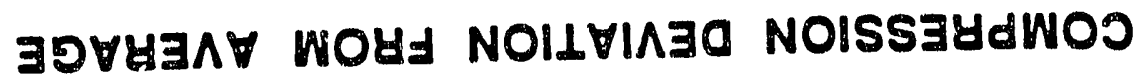




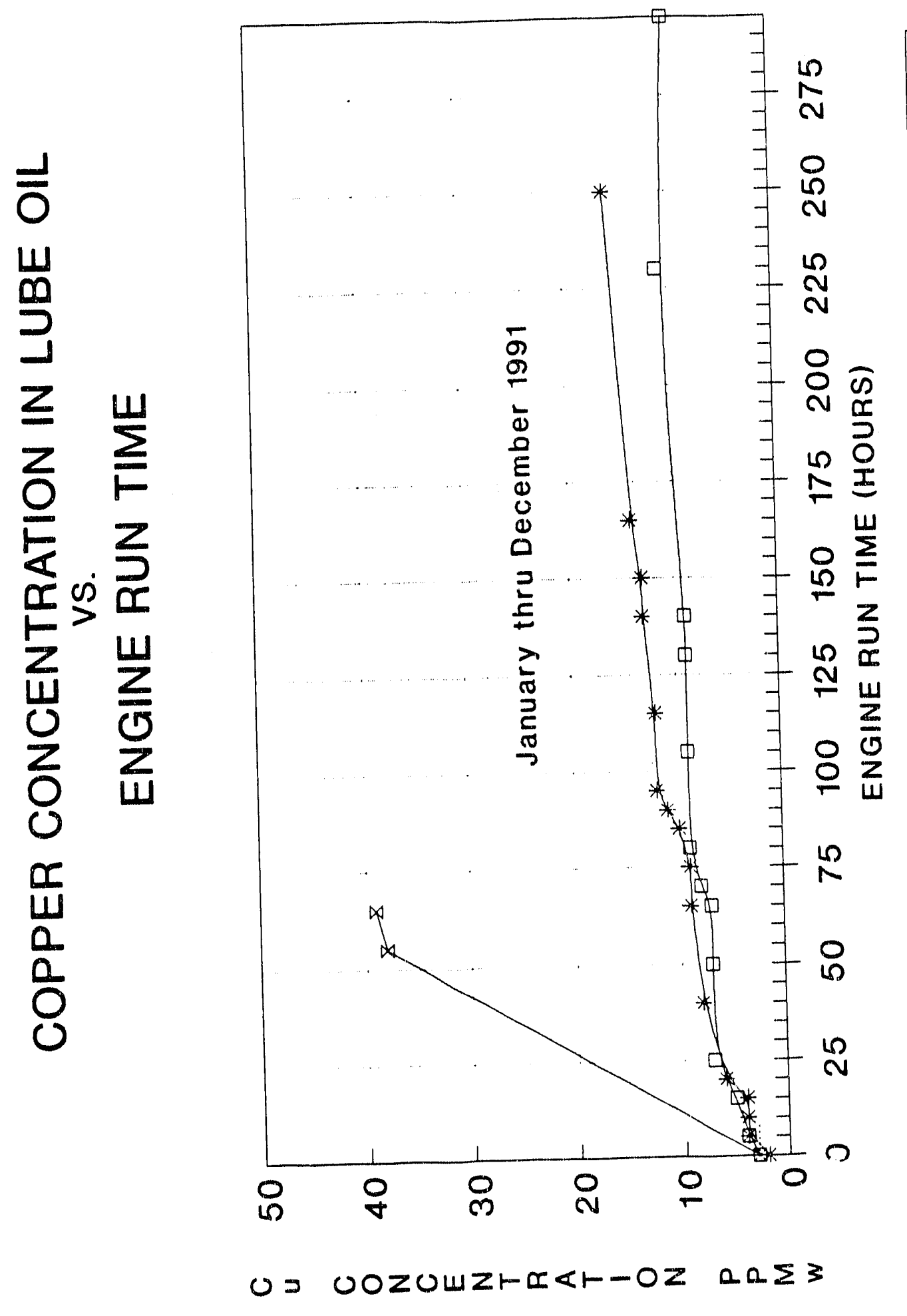




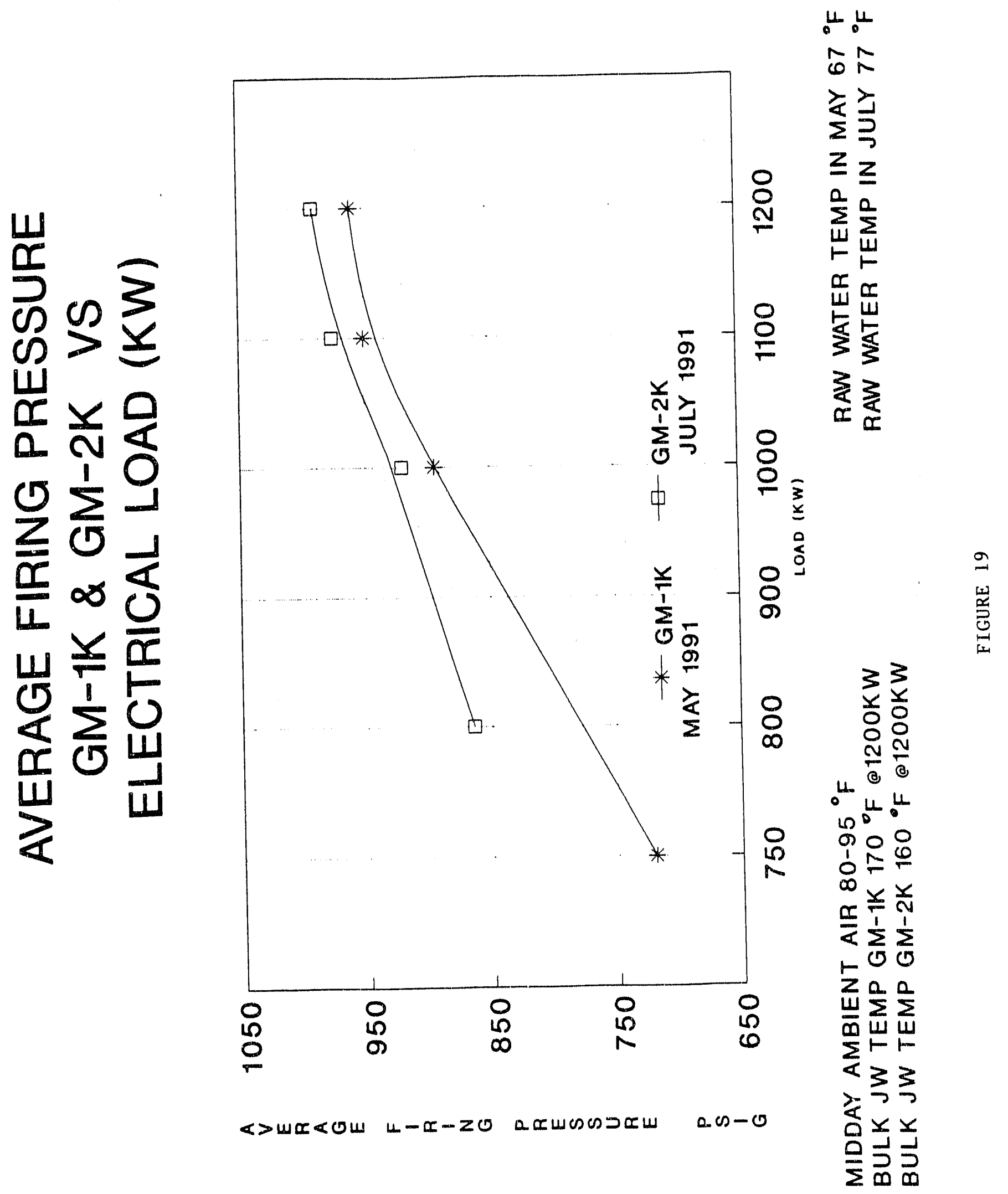




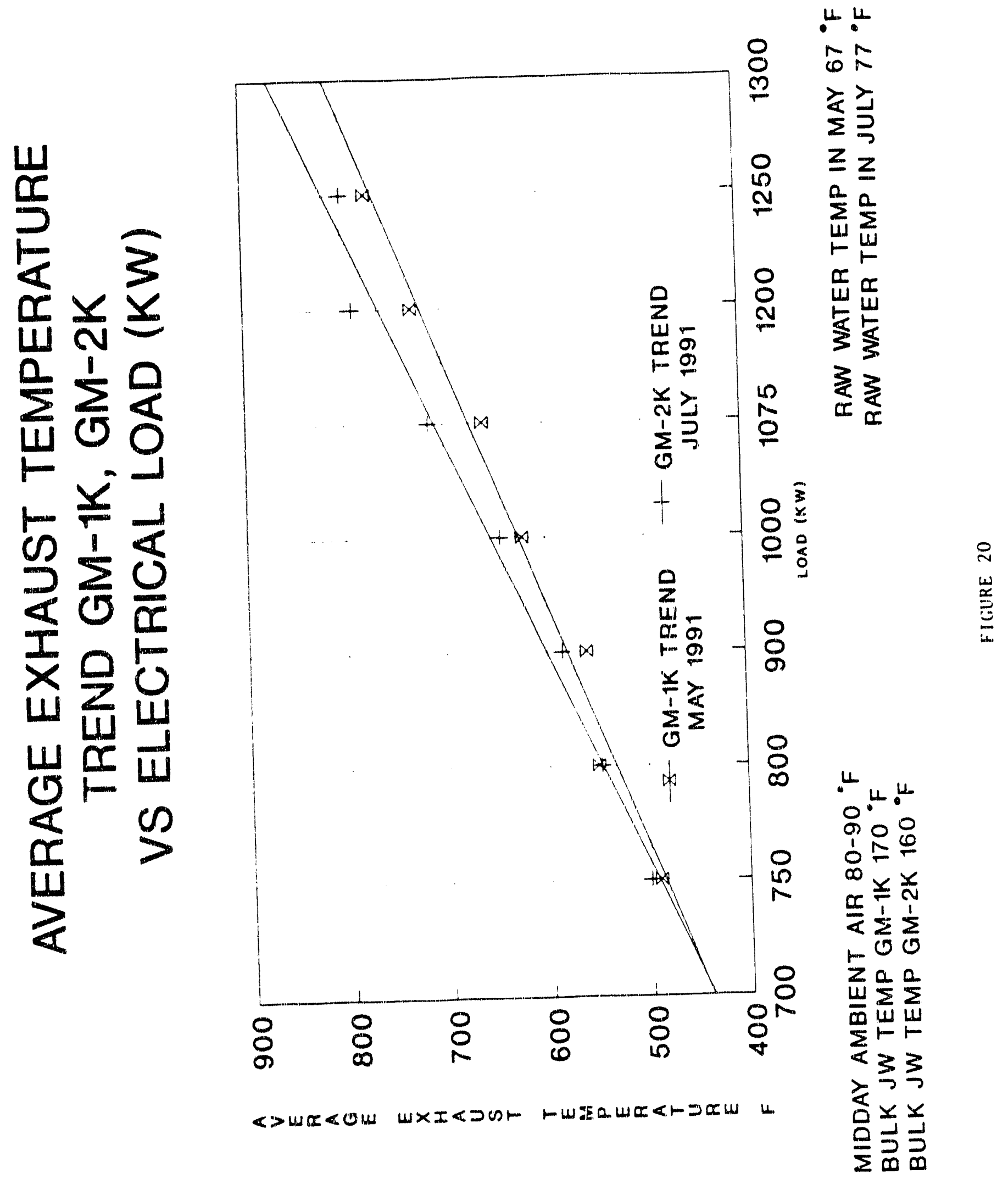


ENGTNTERING EYALUATION OF TBE GHNERAT MOTORS (GX) DIFSEL RATING AND CAPABITITIES (V)

APPENDIX A

ENGINE SPECIFIC TERMS 


\section{APPENDIX A}

\section{DEEINITION OF TERMS}

brake borsepower--a standard measure of power output for engines. One horsepower being $33000 \mathrm{ft}$ lb per minute. Brake horsepower is the actual power output at the end of the crankshaft available for doing work. Originally measured on a "brake" is now most commonly measured on a dynamometer.

brake mean effective pressure-sometimes referred as specific torque. The theoretical constant pressure which can be imagined exerted during each power stroke of the engine to produce power equal the the brake horsepower. The formula for bmep is bhp $x$ $12 \times 33000 / D N$ where bhp is brake horsepower, $D$ is the total displacement of all cylinders in cubic inches, and $N$ in the engine speed in rpm. For this engine, $D=10,102$ cubic inches, $N=720$ rpm, bhp is estimated at 1720 bhp at $1200 \mathrm{kw}$. Consequently, bmep at rated load is $1720 \times 12 \times 33000 / 10102 \times 720$ or $23.6 \mathrm{psi}$.

cylinder bead--bolts at the top of the cylindrical liner against which the piston compresses the air/fuel mixture. Houses the exhaust valves, fuel injector and cylinder test cock (valve) uses to take compression readings.

cylinder compression--a measure of the pressure developed in a cylinder as a result of the pistons movement. For our cleveland diesel engine, the initial charge of air in each cylinder is compressed to $550-600 \mathrm{psig}$ and roughly $600^{\circ} \mathrm{F}$ to $700^{\circ} \mathrm{F}$ before the fuel is injected. Since a 45 cetane fuel's ignition temperature is about $480-500^{\circ} \mathrm{F}$, the fuel ignites by itself shortly after being injected into the cylinder. For this reason, the diesel is called a CI (compression ignition) engine.

continuous rating--according to Edward $F$. Obert in Internal combustion Engines and Air Pollution, pp. 50-55, "From the results of full-power tests the engineer can rate the engine for commercial use. For tractor engines the rating is approximately 60\% of maximum. This means that the manufacturer guarantees the engine to develop 60 percent of the maximum power for an unlimited time." This is called the continuous rating.

diesal engine--an internal combustion engine that uses nigh compression ratios and timed/metered injection of fuel to ignite the air/fuel mixture. Diesels do not have spark plugs as do gasoline engines.

exhaust temperature-temperature of the exhaust gases is taken in the exhaust elbow (exhaust pipe) about 18 inches from the exhaust valves. We have remote readout on this in the 108 operator room. Normal temperatures at full load are from $750^{\circ}$ to $850^{\circ} \mathrm{F}$. Abnormal high temperatures can be caused by leaking exhaust valve seat, high exhaust back pressure, lots of fuel being injected compared to a cylinder with average exhaust temperature- to name a few. Low exhaust temperatures generaliy indicate poor injector performance, for example, not enough fuel is injected, 
the fuel is not atomized properly, or the injector linkage is binding or stuck.

Firing pressuxe--once the injector has delivered its quantity of pressurized fuel and ignition takes place, combustion of the air fuel mixture quickly raises the pressure in the cylinder to 9501050 psig (at full load). Monitoring this pressure does several things. One, it provides the means to determine the balance of the engines load between cylinders. Two, changes in the pressure over engine run time allows the engineers and mechanics to determine how well the power pack is performing and how quickly its break-in.

Iriction horsepower--The power required to run an engine (fhp) is the difference between power developed on the piston (inp) and power delivered by the crankshaft (bhp). This friction horsepower is due to (a) friction of the moving parts of the engine, and (b) pumping losses, according to Diesel. Engineering Handbook, $12 \mathrm{th}$ ed. fuel injector-a device for compressing the fuel oil to a high (1400 psig) pressure, metering the precise amount, and injecting the fuel into the cylinder at the proper moment.

full floating design--of the piston pin and bushing refers to the ability of the pin and the bushing to rotate, the pin in the bushings, and the bushing in the rod eye due to clearance provided by design.

indicated horsepower--power developed in the engine cylinder. inp $=$ PLAN/33000, where $P$ is indicated mean effective pressure, I is piston stroke, $A$ is piston area and $N$ is number of power strokes per minute (for two cycle this it rpm).

kilowatt (kw)--a measure of electrical power, equivalent to 1000 watts or 1.341 horsepower.

mirror finish--Cleveland Diesel Engine Division of General Motors Corporation, material specification for surface finish inspection of piston pins, MS 378 , provides detailed instructions comparing those pins being measured with a surfindicator to the "mirror finish" surface charts enclosed. Sample traces of two acceptable piston pins shown on page 3 of MS 378 meet the Arithmetic Average definition of a $1.5-2.0$ microinch AA finish. This document actually defines GM's "mirror finish" requirement for piston pins in detail.

OM--stands for Original Equipment Manufacturer. For this engine, the OEM was General Motors who today still manufacturers diesel engines. Most of the original engine divisions have been sold though. For example, the Detroit Diesel line is now marketed by Stewart and Stevenson or Detroit Diesel Allison. The electromotive Division (EMD) is now marketed by a division of Morrison Knudsen (MKW). The Cleveland Diesel Division was absorbed by EMD in 1958 or 1959 who continued to support the design until the 1970 's. The rights to sell Cleveland parts was finally sold to Hatch and Kirk, Inc of Seattle in 1977. Although H\&K advertise that they are the Cleveland OEM, it is quite clear that the OEM began to disappear about 1965.

overload--actualiy indicated by dark grey or blue grey smoke caused by low air/fuel ratio. Engine manufacturers consider overload as that load exceeding their "continuous rating". 
Continuous rating may be only $60 \%$ of maximum developed and tested power.

piston--that component of the power assembly used to convey the explosion or combustion of fuel mixture into raw horsepower at the shaft.

piston pin (wrist pin)--provides the means to transfer piston forces to the connecting rod. The master link between rotating components (the conn rod and crankshaft) and the pistons sliding motion.

piston pin bushing--provides a relatively soft (bronze) bearing surface between the alloy steel wrist pin and the forged steel connecting rod eye

power pack--slang term for an assembly of parts comprising the cylinder head, cylinder liner, connecting rod and bearings, piston with piston rings, piston pin and piston bushings. The pressure vessel in which the air/fuel mixture is burned, and engine horsepower is developed. 


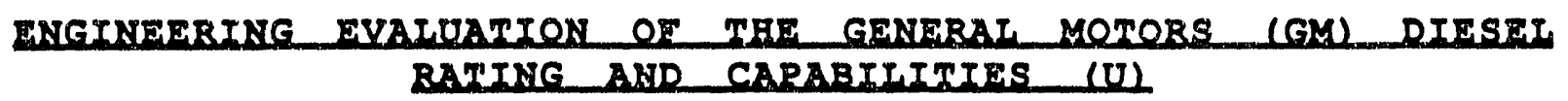

APPENDIX B

DR. LEE A. SWANGER-RESUME' 


\section{Failure}

Analysis

Associates,"inc.

\section{LEE A. SWANGER}

\section{Specialized Prolessional Competence}

Failure analysis of materials and mechanical systems. Mechanical engineering, accident reconstruction. Metallurgical engineering, physical and mechanical metallurgy, and thermodynamics. Foundry process development including ferrous and non-ferrous castings. Fowder metallurgy and powder rolling. Electrochemistry, including electroplating and corrosion. Materials testing, fatigue, and fracture. Metal matrix and polymer matrix composites. Tribology, friction, wear, and lubrication. Internal combustion engine and compressor component design and testing. Sleeve bearing design, manufacture, and failure analysis.

\section{Background and Professional Honors}

B.S. (Metallurgy), Case Institute of Technology, with Highest Honors

M.S. (Materials Science and Engineering), Stanford University

M.B.A. (Markefing/Finance), Cleveland State University

Ph.D. (Materials Science and Engineering), Stanford University, with Distinction

Principal Engineer, Miami Ofrice Director,

Failure Analysis Associates, Inc.

Managing Engineer, Washington D.C. Ofrice Director, Failure Analysis Associates

Director, Research and Development, Imperial Clevite, Inc.

Associate Director, Product Development, Gould Inc., Engine Parts Division

Manager, Tribology and Bearing Research, Gould Laboratories, Materials Research

Associate Senior Research Metallurgist. General Motors Research Laboratories

Lecturer, Metallurgical Engineering. Cleveland State University

Visiting Research Associate, Metallurgical Engineering, Ohio State University

Registered Prolessional Mechanical Engineer, Calilornia \#M23275

Registered Prolessional Metallurgical Engineer, Ohio $\$ 44024$

Registered Professional Engineer, Virginia \#15492

Registered Prolessional Engineer, Florida \#37207

Tau Beta Pi, Sigma Xi, Beta Gamma Sigma

National Merit Foundation Scholarship

Fellowships: Xerox Corporation; IBM Corporation; Hertz Foundation

Member: American Sociely for Metals; American Society for Testing and Materials; American Sociefy for Mechanical Engineers; Society of Automotive Engineers

Interviewer, Hertz Foundation Fellowship Project

\section{Patent}

Patent 4,333,215: Bearing material and method of making. June 8, 1982.

\section{Selected Publications}

"Investigation of the Reliability of Solid Aluminum Main Bearings in Emergency Diesel Generators," gth International Conference on Structural Mechanics in Reactor Technology, Volume D, Lausanne, Switzerland, August 1987 (with S. A. Rau and M. M. Vogler). 
APRENDIX C

108-1K DIMENSIONAL CHECKS, 2/18/91 


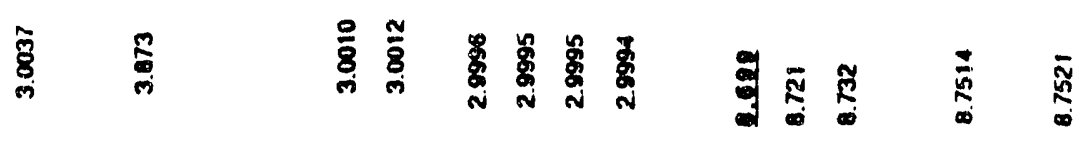

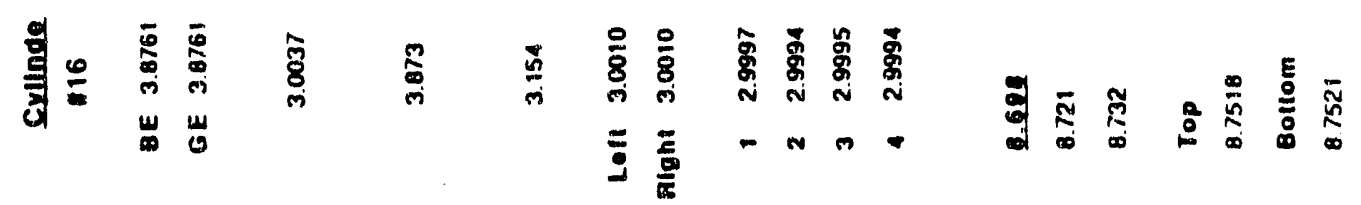

ไั

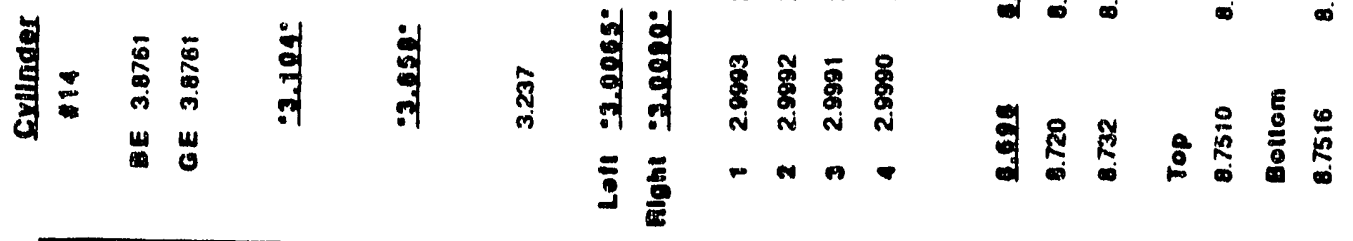

กับ

衰:

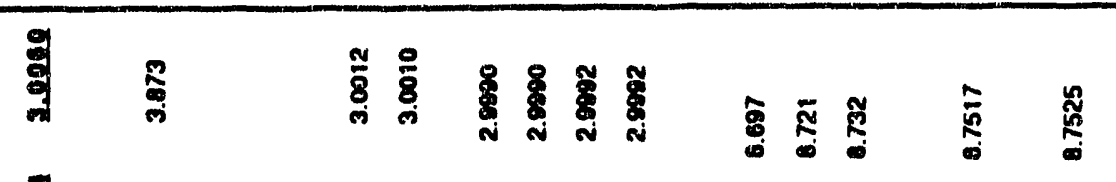

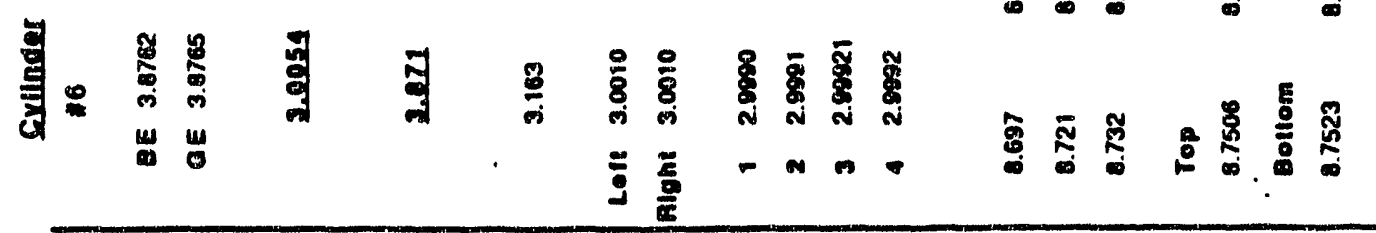

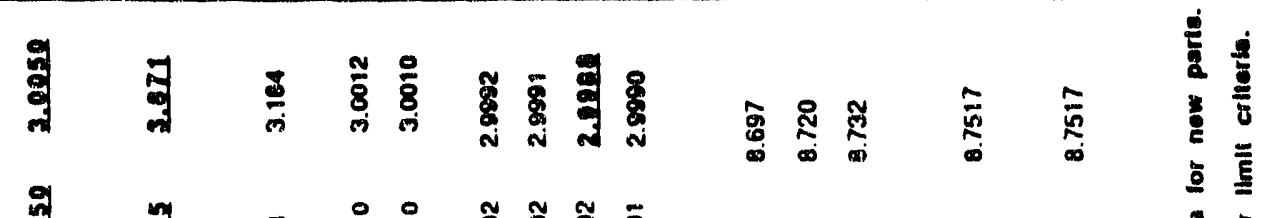

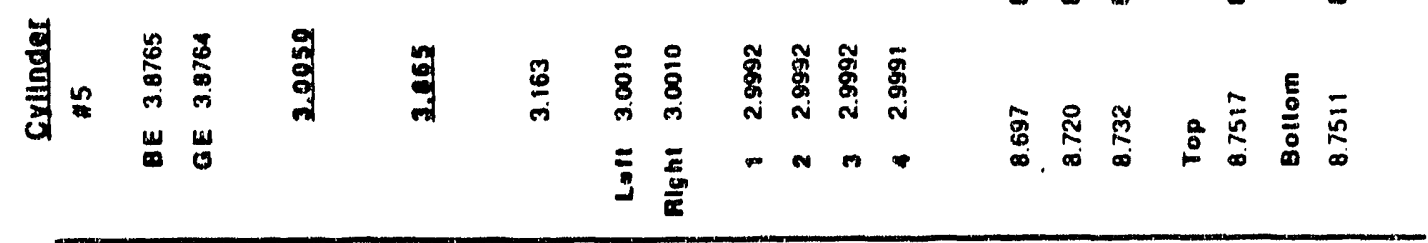

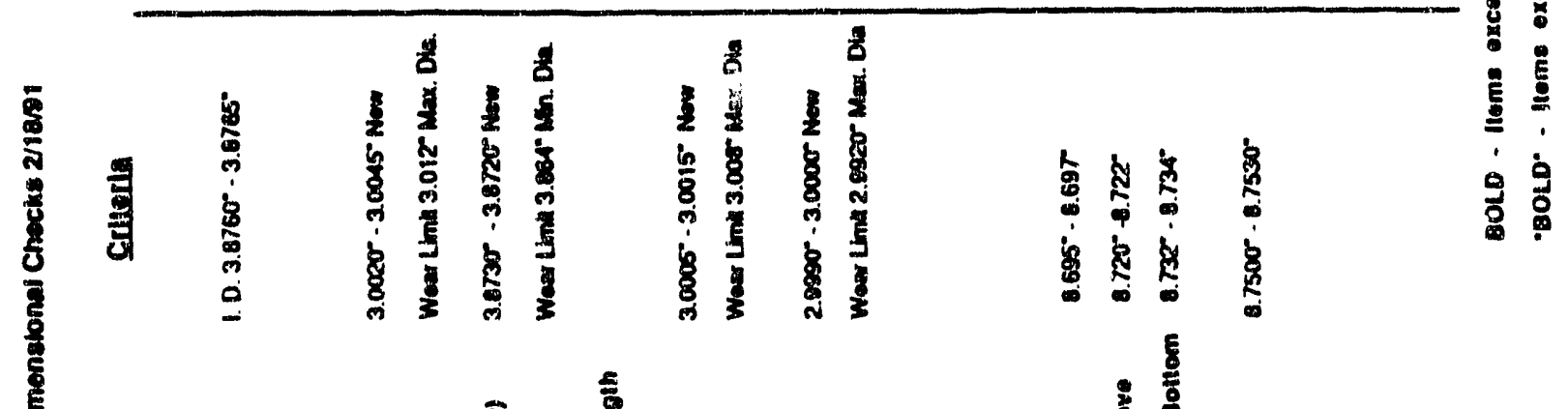

| 
ENGINBFRING EYALUATION OF THE GFNGRAL MOTORS (GM) DIESEL BATING AND CAPABIIITIES (U)

\section{APPENDIX D}

PAUL J. LOUZECKY-RESUME' 


\author{
PAUL J. LOUZECKY \\ 476 SARSFIEID DRIVE \\ ROCHESTER HILLS, MI 48307 \\ $313-853-3992$
}

\title{
PROFESSIONAL EXPERIENCE
}

Fifty-seven years experience in mechanical engineering specializing in internal combustion engine design, manufacture, test and service for the automotive, stationary utility, marine and specialized applications industries. The last 15 years have been concentrated in the consulting, technical advisor, forensic engineering and expert witness activities in the internal combustion engine discipline.

\section{EXPERIENCE}

\section{5 to Present: Independent Consultant}

Extensive range of consulting experiences utilizing all basic engineering disciplines. A representative cross sectional listing of assignments follows:

Komatsu - Engine design for 8, 12, 16 cylinder diesel engines -- current production.

Teledyne - Piston \& rotary wankel engine design including water cooled engine for voyager aircraft.

Williams Engineering \& Research Corp. Diesel \& gas engine design $160 \mathrm{HP}$ diesel, $130 \mathrm{HP}$ and $40 \mathrm{HP}$ gas.

GM/Vauxhaul - Corrected design flaws in 8 cylinder in-line causing piston \& liner scuffing and head distortion.

Cumnins Engine Co. - Corrected crankshaft torsional vibration, piston scuffing and lube oil problems.

GM/Research Labs - Main Battle Tank engine redesign, build, and test within 8 months.

Yonkers Wastewater Treatment Plant Corrected multitude of problems to large bore medium speed diesel including connecting rod repair, securing flywheel to crankshaft, bearing failures, gear train torsional vibration analysis and test. 
Paul J. Louzecky Page 2

1970 to 1975
1963 to 1970
NRC/Brookhaven Laboratories/Battelle Pacific Northwest Laboratories - Team member for reviewing Emergenc'y Diesel Generator reliability and operability problems.

\section{Detroit Diesel Engine Division, General} Motors Corporation

Department Manager/Chief Engineer. Design and development of a V8, 4 cycle diesel truck engine, both naturally aspirated and turbocharged. Analytic and vibration design and testing on engines for performance.

Design of a high pressure, high-speed fuel injection pump for use on a rotary combustion diesel engine. Each pump plunger designed to deliver fuel 4000 times per minute.

Inter Divisional loan to the Engineering Staff of General Motors Corporation to design and develop a low specific fuel consumption stratified-charge automotive gasoline engine.

Supervised the engineering and design of three rotary combustion diesel engines. Assisted in the design and development of the rotary combustion gasoline engine.

Executive Engineer on the MBT-70 Main Battle Tank Program. Work consisted of solving vehicle-related problems, such as power plant problems including cylinder block cracking. piston scuffing, engine and power plant torsional vibrations; vehicle track and wheel problems and silencer, fuel tank and gun mount vibrations, vehicle performance and evaluation studies.

\section{Research Laboratories, General Motors Corporation}

Supervisory Research Engineer in the Mechanical Research and Special Projects Departments. Conducted work on compact locomotive engines; thermal, energy storage automobile with stirling engine lemissions free); thermal energy storage submarine engine (Stirling engine); continuous casting 
Paul J. Louzecky Page 3

1963 to 1963

1958 to 1963

1935 to 1958 machine for casting many metals, including steel; transportation studies and very high speed transportation systems; fuel injection studies; and hovair vehicle studies.

\section{Waukesha Bearing Company}

Consulting Engineer. Conducted a market research study on the potential market for internal combustion engine bearings.

\section{Nordberg Manufacturing Company}

Chief Engineer, Engineering, Installation and Service Departments of the Engine Division. In charge of the engineering and the administrative operation of these departments, including all design, research, development and testing of new engines as well as improving all production two-cycle and four-cycle diesel, DUAFUEL, TRIFUEL, spark-ignition, and propane engines, both naturaliy aspirated and turbocharged.

Designed and developed a number of engines to burn very heavy fuels and developed new engine lubricating oil filtering systems that extended the life of lubricants used in the engines. Work also included the design and development of the welded engine crankcases and other structures reducing their weight and improving their operation. Responsibilities also included the installation service and customer contact work related to these responsibilities.

\section{Cleveland Diesel Engine Division, General} Motors Corporation

Chief Technical Engineer. In charge of Analytical Design, Vibration, Instrumentation, Engineering Welding Design, Welding repair, Metallurgy, Chemical Laboratory, Instruction Books, and Research and Development Sections. Design and development of many engines both 2 and 4 cycle and free piston engines. Design of over fifty different types of internal combustion engines. 
Paul J. Louzecky

Page 4

Supervisor of Special Problems Section.

Design and development of a submarine engine to run under water with a closed-loop intake and exhaust system.

Head of Analytical Design Section. Responsible for all. stress analysis work on engine design, vibrations, governing, engine performance and electrical power plant systems. Design and development of all types of internal combustion engines and related power plant installation problems.

1934 to 1935

\section{Weatherhead Company}

Assistant in Research Laboratory. Developed new hydraulic equipment, very high pressure flexible hose, automotive and aircraft fittings and related automotive hardware and accessories. Developed copper brazing technology.

$1933-1934$

\section{Electric Products Company}

Assistant Chief Draftsman. Designed and developed specialized electrical generators, platers, welders, switchboards, motors and other electrical machinery.

\section{EDUCATION}

M.S. 1933 Mechanical Engineering, Case Western Reserve University, Cleveland, Ohio

Graduate Thesis: "Dynamic Flow Characteristics of Molten Lead"

B.S. 1932 Mechanical Engineering, Case Western Reserve University, cleveland, Ohio

\section{PROFESSIONAL AND TECRNICAL SOCIETY MEMBERSEIPS}

Registered Professional Engineer, State of Ohio (E-003068) American Society of Mechanical Engineers Society of Automotive Engineers Sigma Xi Honorary Science Fraternity ASME Diesel and Gas Power Committee 
Paul J. Louzeck.y

Page 5

\section{TECFNICAI SOCIETY PAPERS}

"Burning of Heavy Fuels in a Mediun Speed, High B.M.E.P. Engine," American Society of Mechanical Engineers Palper No. 63-OGP-13, presented at O.G.P. Meeting in St. Louis, Missouri, May 19-23, 1963.

"Vibrations in River Towboats," Society of Automotive Engineers, Paper No. 699A, presented at Marine Propulsion Meeting, May 14-15, 1963, st. Louis, Missouri.

"Design and Development of a Two-Cycle Turbocharged Diesel Engine," American Society of Mechanical Engineers Paper No. 56-A-100, presented at the ASME Annulal Meeting, New York, N.X., November $25-30,1956$.

Received award for Best ASME-OIBP Paper Presented in 1956

\section{PATEATS}

U.S. Patent No. 2,728,331, "Engine Lubrication and Piston Cooling," December 27, 1955.

U.S. Patent No. 3,177,997, "Electric Clutch and Automatic Starting for Engines," April 15, 1.965.

U.S. Patent No. 3,800,179, "Self-Gleaning Spark Plug," March $26,1974$.

U.S. Patent No. 3,861,837, "Liquid Cooled Rotor Housing," January 21, 1975.

U.S. Patent No. 3,877,852, "Rotary Engine Drain Pump Arrangement," April. 15, 1975.

Patent on "Rotary Machine Apex Seal."

Patent on "Split Phasing Gear for a Multi-Rotor Rotary Combustion Engine."

U.S. Patent No. 3,945,775. "Rotary Combustion Engine Damped Apex Seal," March 23, 1976. 


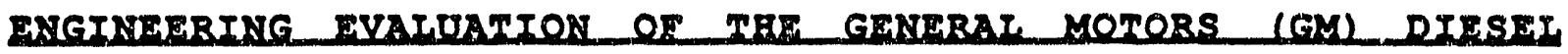
RATING AND CAPABILITIES (U)

APPENDIX $\mathbf{E}$

SURFACE FINISH OF METALS BY

THE ISM COMMITTEE ON SURFACE FINISH

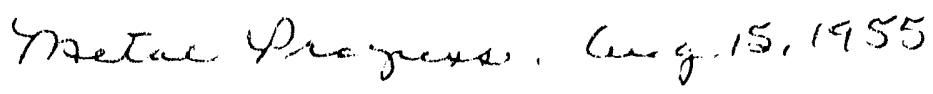

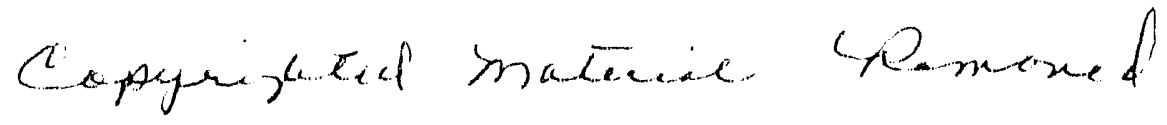




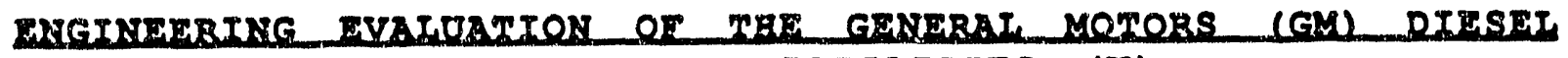
BATING AND CAPABITITIRS (O)

\section{ARPENDIX F}

EXPLANATION OF ARITHMETIC AVERAGE SUREACE FINISH 


\section{Explanation of Arithmetic Average Surface finish}

Mathematically idealized surface:

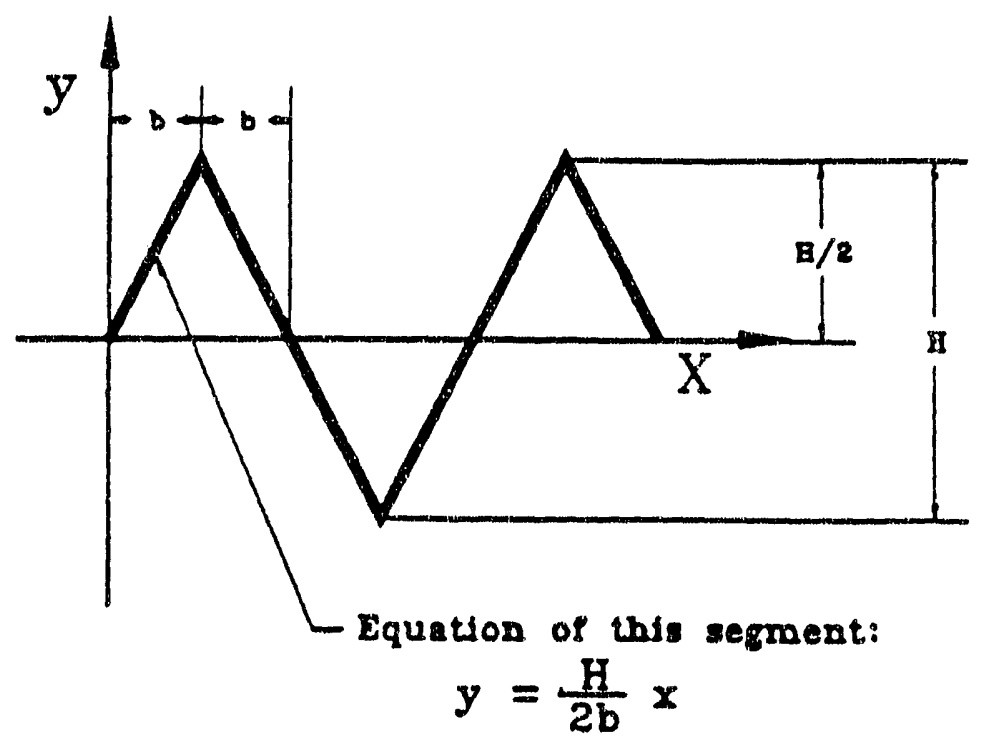

For a given length $L$ of mean surface, if the absolute values of the areas of the peaks above the mean surface and valleys below it are added UP and divided by $L$, the average deviation from the mean surface is obtained. This is referred to as $A A$, arithmetic average. For the mathematically idealized surface above:

$$
A A-\frac{1}{L} \int_{0}^{2} y d x
$$

Since the surface is symmetric, integrate from zero to $b$ and double the result. $L$ then equals $2 b$ :

$$
A A-\frac{1}{2 b}\left[2 \int_{0}^{b} \frac{H}{2 b} x d x\right]-\frac{1}{b}\left[\frac{H}{2 b} \int_{0}^{b} x d x\right]-\frac{H}{2 b^{2}}\left[\frac{x^{2}}{2}\right]_{0}^{b}-\frac{H}{2 b^{2}}\left[\frac{b^{2}}{2}\right]-\frac{H}{4}
$$

So for a given $A A$ reading, the average peak-to-valley height is 4 times the $A A$ and the mean line to peak height distance is 2 times the $A A$. 
HNGINEFRTNG FYALUATION OF TAE GENERAT MOTORS (GM) DTESFI BATING AND CARABITITIES (UI)

APRENDIX G

CSWE CONDITION REPORTS

GM-1P AND GM-2P 


\begin{tabular}{|c|c|}
\hline $\begin{array}{l}\text { cligine ID } \\
\text { Cylinder ID }\end{array}$ & $\begin{array}{l}\text { Bushin } \\
\text { PIn ID }\end{array}$ \\
\hline $\begin{array}{l}108-1 P \\
3 / 18 / 91\end{array}$ & $3 N$ \\
\hline$\# 1$ & Pin 1 \\
\hline $\begin{array}{l}108-1 P \\
3 / 18 / 91\end{array}$ & $3 N$ \\
\hline$\# 2$ & Pin \#2 \\
\hline $\begin{array}{l}108-1 P \\
3 / 18 / 91\end{array}$ & $3 N$ \\
\hline$\# 3$ & Pin $\# 3$ \\
\hline $\begin{array}{l}108-1 P \\
3 / 18 / 91\end{array}$ & $3 N$ \\
\hline
\end{tabular}

Bushing Condition

PIn Condition

Almost New - Tin coating still apparent on $O D \& I D$, very small amount of bronze showing on ID, Discolor - oil groove area but not raised.

Straight Bore, Very small amount of indications on circumference. Oil groove "shadow" from Piston Bushings, Slightly less than mirror finish. End marked "B N"

Almost New - Tin coating still apparent on OD \& ID, very small amount of bronze showing on ID, Discolor - oil groove area but not raised.

Straight Bore, Indications on circumference along entire pin, Slightly less than mirror finish, End marked "B N"

Almost New - Tin coating still apparent on OD \& ID, bronze showing on ID - more apparent on one side, Discolor - oil groove area but not raised.

Straight Bore, Indications on circumference along entire pin, Slightly less than mirror finish, End marked "B N"

Almost New - Tin coating still apparent on OD \& ID, bronze showing on ID, Discolor - oil groove area but not raised.

Straight Bore, Some slight black marking at piston pin bushing area, Less than mirror finish, Oil groove "shadow" from Piston Bushings

(Note: Shipped to Florida per R. E. Gross)'

108-1P $3 \mathrm{~N}$

$3 / 18 / 91$

\#5 Bin 5

108-1P $3 N$

$3 / 18 / 91$

\#6 Pin \#6

108.1P $3 N$

$3 / 18 / 91$

\#2 Pin 1

108-1P $\quad 3 N$

$3 / 18 / 99$

\#8 Pin \#8

108.1P $\quad 3 \mathrm{~N}$

$3 / 18 / 91$

\# Pin \#9
Almost New - Tin coating still apparem on OD \& ID, bronze showing on ID, Discolor - oil groove area but not raised.

Straight Bore, Indications on circumference along entire pin. Slightly less than mirror finish, End marked "B N"

Almost New - Tin coating still apparent on OD \& ID, bronze showing on ID, Discolor - oil groove area but not raised.

Straight Bore, Indications on circumference along entire pin, Slightly less than mirror finish, End marked "B N", Oil groove "shadow" from Piston Bushings

Almost New - Tin coating still apparent on OD, Approx. $50 \%$ of tin gone on ID, bronze showing on ID, Discolor - oil groove area but not raised.

Straight Bore, Indications on circumference at piston pin bushing area, Slightly less than mirror finish, End marked "B N", Oil groove "shadow" from Piston Bushings

Almost New - Tin coating still apparent on $O D \& 1 D$, very small amount of bronze showing on $1 D$, Discolor - oil groove area but not raised.

Straight Bore, Indications on circurnference along entire pin, Slightly less than mirror finish, End marked "B N", Oil groove "shadow" from Piston Bushings

Almost New - Tin coating still apparent on OD \& ID, smail amount of bronze showing on ID, Discolor - oil groove area but not raised.

Straight Bore, Indications on circumference along entire pin, Slightly less than mirror finish, End marked "B N", Oil groove "shadow" from Piston Bushings

löriginai engine pl piss "H4 and \#15 were switched and in-

correctly labeled cyl \#10\&\#12 from engine P2. FaAA wis able to match pins with bushings due to phvsical apnearance and wear. 


\begin{tabular}{|c|c|}
\hline $\begin{array}{l}\text {-riys... : } \\
\text { Cyllnder ID }\end{array}$ & $\begin{array}{l}\text {-Ushin } \\
\text { Pin ID }\end{array}$ \\
\hline $\begin{array}{l}108-1 P \\
3 / 18 / 91\end{array}$ & $3 N$ \\
\hline$\# 10$ & Ein \# 10 \\
\hline $\begin{array}{l}108-1 P \\
3 / 18 / 91\end{array}$ & $3 N$ \\
\hline$\# 11$ & Pin $\# 11$ \\
\hline $\begin{array}{l}108-1 P \\
3 / 18 / 91\end{array}$ & $3 N$ \\
\hline$\# 12$ & Pin 12 \\
\hline $\begin{array}{l}108-1 P \\
3 / 18 / 91\end{array}$ & $3 N$ \\
\hline$\# 13$ & Pin \#13 \\
\hline $\begin{array}{l}108-1 P \\
3 / 18 / 91\end{array}$ & $3 N$ \\
\hline$\# 14$ & Pin \#14 \\
\hline $\begin{array}{l}108-1 P \\
3 / 18 / 91\end{array}$ & $3 N$ \\
\hline$\# 15$ & Pin井 15 \\
\hline $\begin{array}{l}108-1 P \\
3 / 18 / 91\end{array}$ & $3 N$ \\
\hline$\# 16$ & Pin $\$ 16$ \\
\hline
\end{tabular}

Almost New - Tin coating still apparent on $O D \& 1 D$, very small amount of bronze showing on ID, Discolor - oil groove area but not raised.

Straight Bore, Indications on circumference along entire pin, Slightly less than mirror finish, End marked "B N"

Almost New - Tin coating still apparent on $O D \& 1 D$, bronze showing on $1 D$, Very slight discolor at oil groove area, not raised.

Straight Bore, Indications on circumference along entire pin, Slightly less than mirror finish, End marked "B N"

Almost New - Tin coating still apparent on OD \& ID, small amount of bronze showing on ID, Discolor - oil groove area but not raised.

Straight Bore, Indications on circumference along entire pin, Slightly less than mirror finish, End marked "B N"

Almost New - Tin coating still apparent on OD \& ID, very small amount of bronze showing on 10 , Discolor - oil groove area but not raised.

Straight Bore, Indications on circumference along entire pin, Slightly less than mirror finish, End marked "B N", Oil groove "shadow" from Piston Bushings and Piston pin bushing

Almost New - Tin coating still apparent on OD \& ID, very small amount of bronze showing on ID, Discolor - oil groove area but not raised.

Straight Bore, Indications on circumference along entire pin, Slightly less than mirror finish, End marked " $B N^{N}$, Oil groove "shadow" from Piston Pin Bushings

Almost Now - Tin coating still apparent on $O D \& 1 D$, very small amount of bronze showing on ID, Discolor - oil groove area but not raised.

Straight Bore, Indications on circumference along entire pin, Some slight black marking at piston pin bushing area, Slight less than mirror finish

(Note: Shipped to Florida per A. E. Gross) ${ }^{2}$

Almost New - Tin coating still apparent on $O D \& 10$, very small amount of bronze showing on 10 , Discolor - oil groove area but not raised.

Straight Bore, Indications on circumference along entire pin, Slightly less than mirror finish, End marked "B N", Oil groove "shadow" from Piston Bushings

2

See attached letter from FaAA showing matchup of pins and bushings from cylinders 4, 15 (P1) and 10, 12 (P2). Pins " $C$ " and " $D$ " were Burgess Norton ' $B-N$ ' pins originally from a set of 16 installed in engine $P I$.

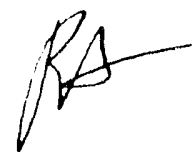




\begin{tabular}{|c|c|c|}
\hline $\begin{array}{l}\text { Englne IU. } \\
\text { Cyllnder ID }\end{array}$ & $\begin{array}{l}\text { Eusimily orand ID } \\
\text { PIn ID }\end{array}$ & $\begin{array}{l}\text { Bushing Condition } \\
\text { PIn Condition }\end{array}$ \\
\hline $\begin{array}{l}108-2 P \\
(3-91)\end{array}$ & Markino Worn Off (?) & $\begin{array}{l}\text { Bushing seized in Con Rod., ID Tin Coating completely gone, Bronze showing } \\
\text { on ID. Black Markings on ID }\end{array}$ \\
\hline$\# 1$ & Pin 1 & $\begin{array}{l}\text { Straight Bore, Indications on circumference along entire pin, Slightly less than } \\
\text { mirror finish, Indications on each end - same side of pin (Material Deposits?) }\end{array}$ \\
\hline $\begin{array}{l}108-2 P \\
(3-91)\end{array}$ & Amer (4 58) & $\begin{array}{l}\text { Wear, OD Tin almost completely gone, ID Tin completely gone, Bronze showing } \\
\text { on OD \& ID }\end{array}$ \\
\hline$\# 2$ & Pin \#? & $\begin{array}{l}\text { Straight Bore, Indications on circumference along entire pin, Slightly le:ss than } \\
\text { mirror finish }\end{array}$ \\
\hline $\begin{array}{l}108-2 P \\
(3-91)\end{array}$ & $11 P$ & $\begin{array}{l}\text { Failed Bushing, } O D \& I D \text { Tin Coating completely gone, Oil groove area raised, } \\
\text { Extrusion started on end, Bronze showing on } O D \& 1 D \text {, wom past ID oil grooves } \\
\text { on one side. }\end{array}$ \\
\hline$\# 3$ & $\operatorname{Pin} \# 3$ & $\begin{array}{l}\text { Straight Bore, Indications on circumference along entire pin, Less than mirror } \\
\text { finish, Black markings at at piston pin bushing location and piston bushing } \\
\text { locations }\end{array}$ \\
\hline $\begin{array}{l}108-2 P \\
(3-91)\end{array}$ & $11 P$ & $\begin{array}{l}\text { Wear - OD Tin Coating almost completely gone, ID Tin Coating completely gone, } \\
\text { Oil groove area discolor, Bronze showirg on OD \& ID, Black Markings on ID }\end{array}$ \\
\hline$\# 4$ & $\operatorname{Pin} \# 4$ & $\begin{array}{l}\text { Straight Bore, Indications on circumference along entire pin, Oil groove "shadow" } \\
\text { from piston bushings, Slightly less than mirror tinish }\end{array}$ \\
\hline $\begin{array}{l}108-2 P \\
(3-91)\end{array}$ & H11 (3.3) (Let 117) & $\begin{array}{l}\text { Wear - OD Tin Coating still apparem, ID Tin Coating about } 50 \% \text { gone, Oil groove } \\
\text { area discolor, Bronze showing on ID, Black Markings on ID }\end{array}$ \\
\hline$\# 5$ & Pin \#5 & $\begin{array}{l}\text { Straight Bore, Indications on circurnference along entire pin, Slightly less than } \\
\text { mirror finish }\end{array}$ \\
\hline $\begin{array}{l}108-2 P \\
(3-91)\end{array}$ & $2 m ?$ & \\
\hline$\# 6$ & Pin \#6 & $\begin{array}{l}\text { Straight Bore, Indications on circumference along entire pin, Less than mirror } \\
\text { finish, Black markings at piston pin bushing location }\end{array}$ \\
\hline $\begin{array}{l}108-2 P \\
(3-91)\end{array}$ & American (M 464 B) & $\begin{array}{l}\text { Wear - OD Tin Coating still apparent, ID Tin Coating about } 50 \% \text { gone, Oil groove } \\
\text { area discolored and rough, Bronze showing on ID, Some Black Markings on ID }\end{array}$ \\
\hline$\# 7$ & Bin $\# 7$ & $\begin{array}{l}\text { Straight Bore, Indications on circumference along entire pin, Oil groove "shadow" } \\
\text { from piston bushings, Slightly less than mirror finish, Slight black markings at } \\
\text { piston pin bushing location, Material Deposits at some oil grooves }\end{array}$ \\
\hline $\begin{array}{l}108-2 P \\
(3-91)\end{array}$ & 3309100 (G C C & $\begin{array}{l}\text { Wear - OD Tin Coating almost completely gone, ID Tin Coating completely gone, } \\
\text { Oil groove area discolor, Bronze showing on OD \& ID, Black Markings on ID, } \\
\text { Small ridges on OD perpendicular to Oil Grooves }\end{array}$ \\
\hline$\# 8$ & Pin \#8 & $\begin{array}{l}\text { Straight Bore, Indications on circumference along entire pin, Oil groove "shadow" } \\
\text { from piston bushings, Slightly less than mirror finish, Slight black markings at } \\
\text { piston pin bushing location, }\end{array}$ \\
\hline $\begin{array}{l}108-2 P \\
(3-91)\end{array}$ & 3302100 (G CX) & $\begin{array}{l}\text { Weai - OD Tin Coating almost completely gone, ID Tin Coating completely gone, } \\
\text { Bronze showing on OD \& ID. Black Markings on ID }\end{array}$ \\
\hline$\# 9$ & Bin & $\begin{array}{l}\text { Straight Bore, Indications on circumference along entire pin, Slightly less than } \\
\text { mirror finish }\end{array}$ \\
\hline
\end{tabular}




\begin{tabular}{|c|c|c|}
\hline $\begin{array}{l}\text { Englne ID } \\
\text { Cylinder ID }\end{array}$ & $\begin{array}{l}\text { Bushiny kicine id } \\
\text { PIn ID }\end{array}$ & $\begin{array}{l}\text { Pisioillg Condition } \\
\text { PIn Condition }\end{array}$ \\
\hline $\begin{array}{l}108-2 P \\
(3-91)\end{array}$ & $11 P$ & $\begin{array}{l}\text { Bushing seized in Con Rod. , ID Tin Coating completely gone, Bronze showing } \\
\text { on ID. Black Markings on ID, Starting to wear past oil grooves on ID }\end{array}$ \\
\hline \multirow[t]{2}{*}{$\# 10$} & Pin \#10 & $\begin{array}{l}\text { Straight Bore, Indications on circumference along entire pin, Slightly less than } \\
\text { mirror finish, Manked "B N" }\end{array}$ \\
\hline & & (Note: Shipped to Florida per R. E. Gross) 1,2 \\
\hline $\begin{array}{l}108.2 P \\
(3.91)\end{array}$ & 112 & $\begin{array}{l}\text { Wear - OD Tin Coating still apparent \& ID Tin Coating completely gone, Oil groove } \\
\text { area discolor \& slight raised surface, Bronze showing some on OD \& ID, Black } \\
\text { Markings on ID }\end{array}$ \\
\hline$\# 11$ & Pin \#11 & $\begin{array}{l}\text { Straight Bore, Indications on circumference along entire pin, Slightly less than } \\
\text { mirror finish, Slight black markings at piston pin bushing location }\end{array}$ \\
\hline $\begin{array}{l}108-2 P \\
(3-91)\end{array}$ & $\operatorname{Amer}(252 \mathrm{G})$ & $\begin{array}{l}\text { Wear - OD \& ID Tin Coating still apparent, Oil groove area discolor, Bronze } \\
\text { showing on ID }\end{array}$ \\
\hline \multirow[t]{2}{*}{$\# 12$} & Pin \#12 & $\begin{array}{l}\text { Straight Bore, Indications on circumference along entire pin, Less than mirror } \\
\text { finish, Slight black markings at piston pin bushing location }\end{array}$ \\
\hline & & (Note: Shipped to Florida per R. E. Gross) 1,2 \\
\hline $\begin{array}{l}108-2 P \\
(0.91)\end{array}$ & $11 P$ & $\begin{array}{l}\text { Wear - OD Tin coating still apparent, ID Tin Coating completely gone, Oll groove } \\
\text { area discolor, Bronze showing on OD \& ID }\end{array}$ \\
\hline$\# 13$ & Pin $\# 13$ & $\begin{array}{l}\text { Straight Bore, Indications on circumference along entire pin, Less than mirror } \\
\text { finish, Slight black markings at piston pin bushing location }\end{array}$ \\
\hline $\begin{array}{l}108-2 P \\
(3-91)\end{array}$ & American (464B) & $\begin{array}{l}\text { Wear-OD \& ID Tin Coating almost completely gone, Oil groove area discolor, } \\
\text { Bronze showing on OD \& ID, Black Markings on ID }\end{array}$ \\
\hline$\# 14$ & Pin \#14 & $\begin{array}{l}\text { Straight Bore, Indications on circumference along entire pin, Slightly less than } \\
\text { mirror finish, Some material deposits on pin }\end{array}$ \\
\hline $\begin{array}{l}108-2 P \\
(3-91)\end{array}$ & 3309100 (G C Cx) & $\begin{array}{l}\text { Wear - OD Tin Coating still apparent, ID Tin Coating completely gone, Bronze } \\
\text { showing on } O D \& 1 D \text {, Black Markings on ID, } \\
\text { Small ridges on } O D \text { perpendicular to Oil Grooves }\end{array}$ \\
\hline$\# 15$ & $\operatorname{Pin} \# 15$ & $\begin{array}{l}\text { Straight Bore, Indications on circumference along entire pin, Oil groove "shadow" } \\
\text { from piston bushings, Slightly less than mirror finish, Some material deposits on } \\
\text { pin }\end{array}$ \\
\hline $\begin{array}{l}108-2 P \\
(3-91)\end{array}$ & $11 P$ & $\begin{array}{l}\text { Wea: - OD Tin Coating completely gone, Some tin coating still apparent on ID, Oil } \\
\text { groove area discolor, Bronze showing on OD \& ID }\end{array}$ \\
\hline$\# 16$ & Pin 16 & $\begin{array}{l}\text { Straight Bore, Indications on circumrerence along entire pin, Slightly less than } \\
\text { mirror finish, Some material deposits on pin }\end{array}$ \\
\hline
\end{tabular}




\section{Failure}

Analysis

Associates

March 26, 1991
Lee A. Swanger, Ph.D., P.E.

iPrincipal Engineer

Engineering and Scientific Services

1 1501 venera Avenue. Sulte 300

- Coral Gables. Fiorida 33146

. (305) 061.7726 lelex $704216 \mathrm{Fax}(305) 005.0248$

FaAA-FL-R-91-03-02

Mr. Robert Gross

Westinghouse Savannah River Co.

Aiken, SC 29802

Via Telecopy: 18035579170

Ref: Savannah River Diesel, FaAA Project No. FL75192

Determination of Wrist Pin and Bushing Matched Pairs

Dear Mr. Gross:

At your request, Failure Analysis Associates, Inc ${ }^{\otimes}(\mathrm{FaAA})$ engineers in the Coral Gables Laboratory have examined four wrist pins (labeled A through D) and four bushings (labeled $A$ through $D$ ) sent to FaAA by Westinghouse Savannah River Co. These components reportedly were removed from the two Cleveland Diesels in the "P" reactor area.

Westinghouse directed FaAA to assume that these four pins and four bushings were paired in either of the two engines, but that the traceability of the pairings may have been lost. Assuming that the four sets were matched during operation, FaAA has made the following assignments based on the physical appearance of the components.

Wrist Bushing Comments

Pin

$\begin{array}{ll}\text { A } & \text { D } \\ \text { B } & \text { C } \\ \text { C } & \text { A } \\ & \\ \text { D } & \text { B }\end{array}$

Both of these were in the worst condition. Heat tint on the pin corresponds to severe wear and burning of bronze in bushing.

Both components were in second worst condition.

Both components were in best condition. Both showed bimodal wear patterns, longitudinally.

Both components were in second best condition. Both showed wear patterns biased in one longitudinal direction.

Very truly yours,

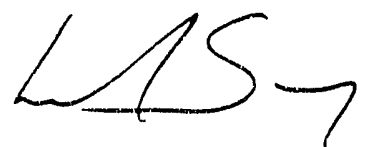

Lee A. Swanger, Ph.D., P.E.

Principal Engineer

Director, Miami Office 
WSRC-TR-92-42-011

March 20, 1992

Page 34 of 34

ENGTNABRTAG EYATUATION OF THE GENERAT MOTORS (GM) DIESEI

RATING AND CARARIIITIES (U)

APPENDIX E

CORRELATION OF COPPER CONCENTRATION IN LUBRICATING OIL TO ACTUAL MEASURED BRONZE BUSHING WEAR 
GM-1K (General Motors) Diesel Piston Pin Bushing, p/n 3309100

$5-15-91$

How does the amount of copper in the engine lubricating oil reported by Analysts Inc of Atlanta compare to all amount calculated or estimated from actual piston pin (wrist pin) bushing measurements. From the 1950 GM Cleveland Navy drawing 81127-S4 105-869367:

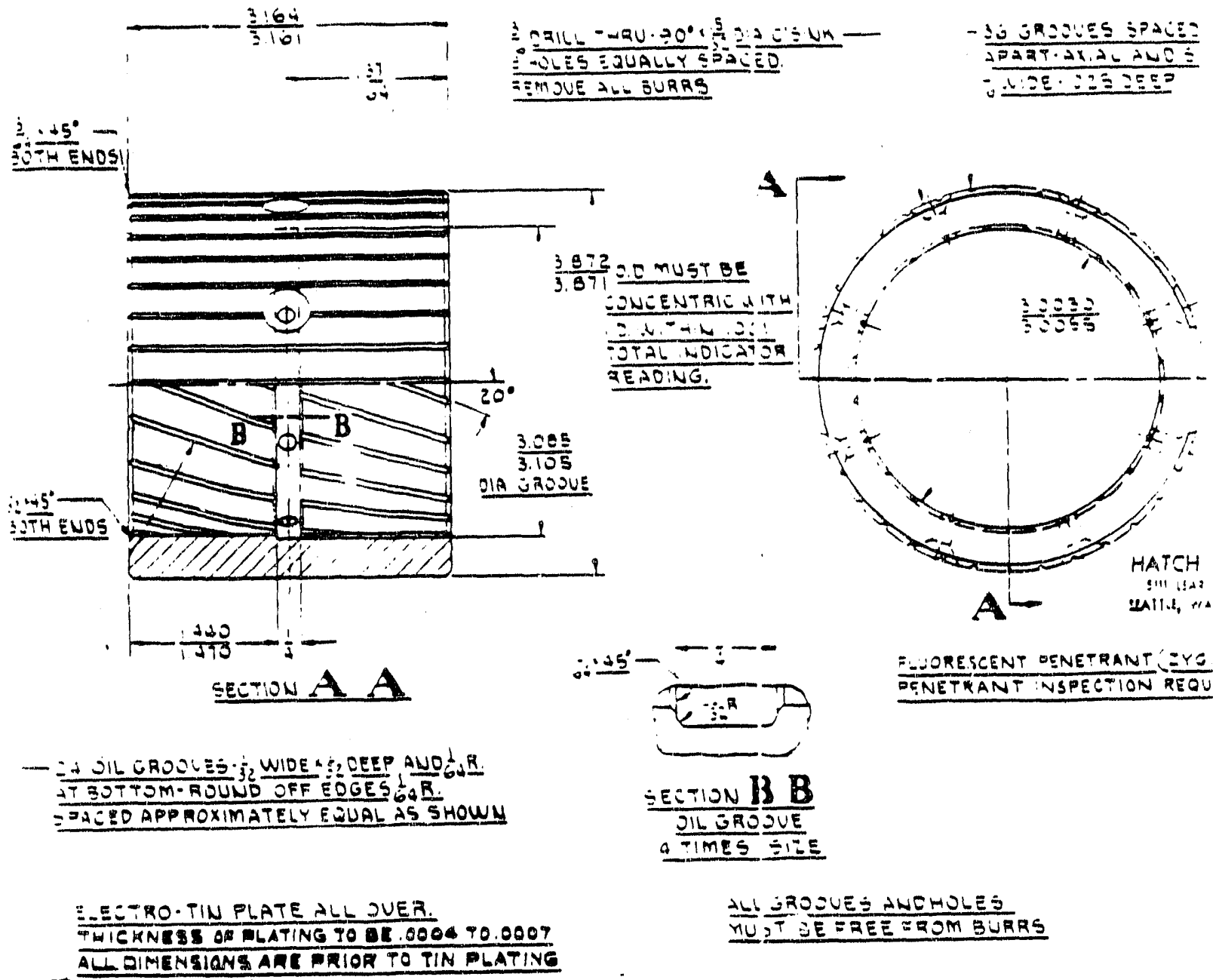

$\begin{array}{ll}\text { Outside Diameter (OD) } & 3.872^{\circ} \\ \text { Wear I imit } & 3.864^{\circ} \\ & \\ \text { Inside Diameter (ID) } & 3.003^{\prime \prime} \\ \text { Wear Limit } & 3.012^{\prime \prime} \\ \text { Length } & 3.164^{\prime \prime}\end{array}$

From machinery's handbook:

Phosphor bronze weighs $0.320 \mathrm{LB} /$ in $^{3}$ and is about $90 \%$ copper $\sim 0.290 \mathrm{LB} /$ in $^{3}$ 
Lube oil system capacity 358 gallons (required to fill 5/14/91)

Use lube oil A444 specific gravity $0.88 \sim 0.90$

So weight of the system's oil is $0.90 \times 358 \mathrm{gal} \times 8.34 \mathrm{LB} / \mathrm{Gal}$ or 2687 LBS $f$

\section{GM-1K Oil Analysis results from 9/90 to 2/91}

From Analysts, Inc. of Atlanta, Georgia Lube Oil Analysis:

$\begin{array}{llll}\text { GM-1K } & \text { Sept. 17, 1990 } & 16 \text { ppm } & \text { copper } \\ \text { GM-1K } & \text { Jan. 18, 1992 } & \text { 30 pom } & \text { copper } \\ \text { GM-1K } & \text { Feb. 26, 1991 } & 38 \text { ppm } & \text { copper }\end{array}$

Were the reported levels of copper in the engine lubricating oil.

How does this reported concentration compare to actual measured metal loss?

Using data obtained by SES QV the following data is collated from inspection report 91-TR-06-247 and wear analysis from September 1990:

First, calculate the volume of metal lost from the inside diameter of the bushings.

"Volume $=\pi / 4$ (worn diameter, $d w^{2}$ - basic diameter, $\left.d b^{2}\right) \times$ length

For example, cylinder number 4 would be calculated as $\pi / 4 \times(3.009-3.003) \times 3.164$

$$
=0.0896 \mathrm{in}^{3}
$$

\begin{tabular}{|c|c|c|c|c|}
\hline$\underset{\#}{\text { CYLINDER }}$ & $\begin{array}{l}\text { SIZE } \\
\text { (ID) }\end{array}$ & $\begin{array}{l}\text { WEAR } \\
\text { (MILS) }\end{array}$ & $d w^{2}-d b^{2}$ & "VOLUM \\
\hline 1 & 3.003 & - & - & - \\
\hline 2 & 3.003 & - & - & - \\
\hline 3 & 3.004 & 1 & 0.006 & 0.0149 \\
\hline 4. & 3.009 & $6-7$ & 0.036 & 0.0896 \\
\hline 5. & 3.004 & 1 & 0.006 & 0.0149 \\
\hline 6. & 3.003 & - & - & - \\
\hline 7. & 3.004 & 1 & 0.006 & 0.0149 \\
\hline 8 & 3.004 & 1 & 0.006 & 0.0149 \\
\hline 9. & 3.010 & 7.8 & 0.042 & 0.1046 \\
\hline 10. & 3.003 & - & - & - \\
\hline 11. & 3.003 & - & - & - \\
\hline 12. & 3.003 & - & - & - \\
\hline 13. & 3.010 & 78 & 0.042 & 0.1046 \\
\hline 14. & 3.003 & - & - & - \\
\hline 15. & 3.004 & $1-2$ & - & 0.0149 \\
\hline 16. & 3.004 & 1 & - & 0.0149 \\
\hline
\end{tabular}

VID $=$ Volume of Metal Lost from the bushing inside diameter

$0.3892 \mathrm{in}^{3}$ 
Next, calculate the volume of metal lost from the bushing's outside diameter (3.8725").

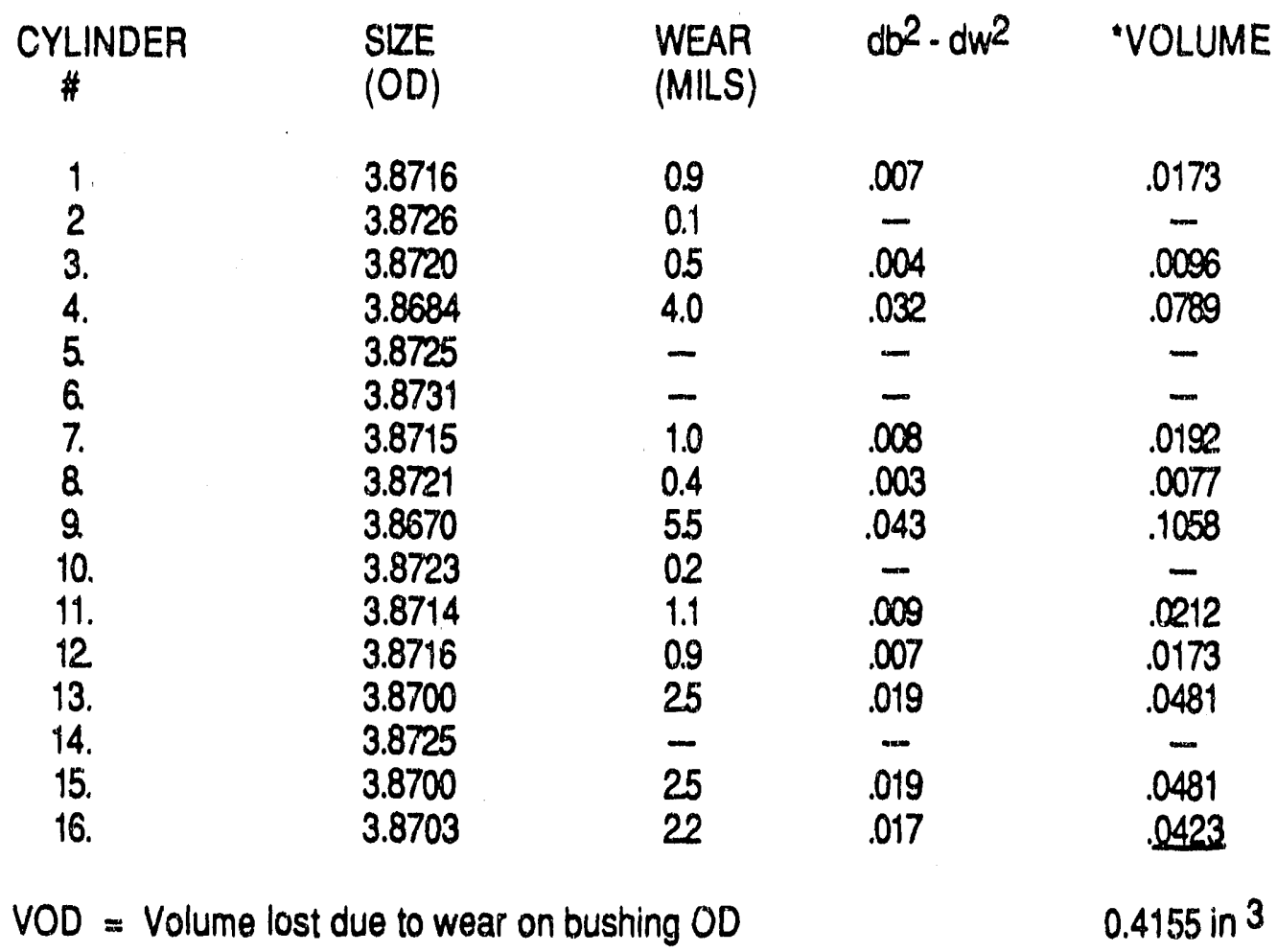

typically,

$$
\begin{aligned}
V_{9} & =\pi / 4 \times(\text { basic diameter } 2 \text { - worn diameter } 2) \times \text { length } \\
& =\pi / 4 \times\left(3.8725^{2}-3.8670^{2}\right) \times 3.164 \\
V_{9} & =0.1058 \mathrm{in}^{3}
\end{aligned}
$$

From sheets 3 and 4 , total metal loss by measurement and calculations VID + VOD $=0.3892+$ $0.4155=0.8047 \mathrm{in}^{3}$.

Calculate parts per million (by weight)

$$
\begin{aligned}
& \text { Copper ppm }=\frac{0.8047 \mathrm{in}^{3} \times 0.290 \mathrm{LB} / \mathrm{in}^{3}}{\text { Oil Weight }} \\
& =\frac{0.233 \mathrm{Lb}}{2687 \mathrm{Lb}} \\
& =87 \text { ppm by weight }
\end{aligned}
$$


From Sheet 2, $16 \mathrm{ppm}$ was measured. Calculated from bushing wear $=87 \mathrm{ppm}$.

Correlation of the calculated ie measured concentrations is the ratio $=87 / 16 \sim 5.5: 1$

Look at February 1991 data, ieported 38 ppm, bushing measuremerics laken from SES QV Report of 2/28/91. January analysis data cannot be compared to actual measurements because the parts were not removed from the engine until February.

February 25, 1991

Cylinder \#

10

$O D$

Volume $(I D+O D)$

$\begin{array}{rlll}5 & 3.005 & 3.865 & .1741 \\ 6 & 3.006 & 3.872 & .0469 \\ 7 & 3.004 & 3.873 & .0140 \\ 14 & 3.104 & 3.860 & 1.7818 \\ 16 & 3.004 & 3.873 & 1.7818\end{array}$

Total Volume of metal lost $=2.0168 \mathrm{in}^{3}$

Then as before, copper ppmw $=2.0168 \mathrm{in}^{3} \times 0.200 \mathrm{LB}^{3} \mathrm{in}^{3}$

2687 LB

Copper ppm $=218$ ppm, measured 38

Correlation of the calculated to measured concentrations is the ratio $=218 / 38 \sim 5.7: 1$

Conclusion: Not able to accurately predict actual metal wear on bushings by using wear metal analysis. Future data may validate or substantiate the 5.5-5.7 correlation ratio. 


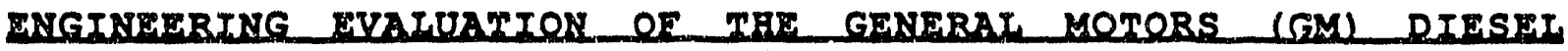 BATING AND CAPABITITIES (U)}

\section{APPENDIX J}

DATA ACQUISITION SYSTEM COMPUTER SCREEN 


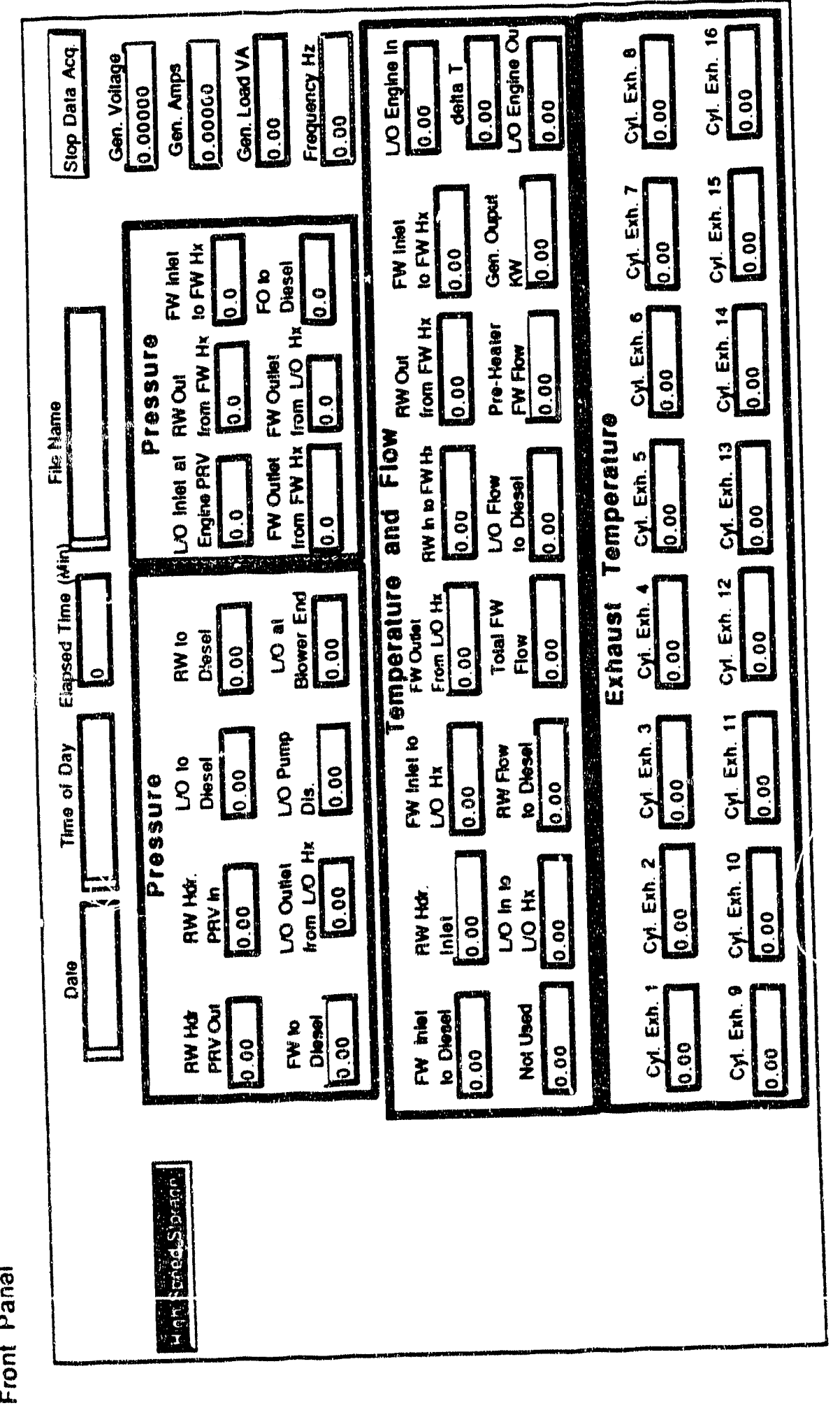




\title{
ENGINBERING EVALUATION OF THE GENERAL MOTORS (GM) DIESEL BATING AND CAPABITITIES (U)
}

\author{
APRENDIX $\mathbf{K}$ \\ TYPICAL ENGINE PARAMETERS DURING PERFORMANCE TESTING \\ GM-1K AND GM-2K
}




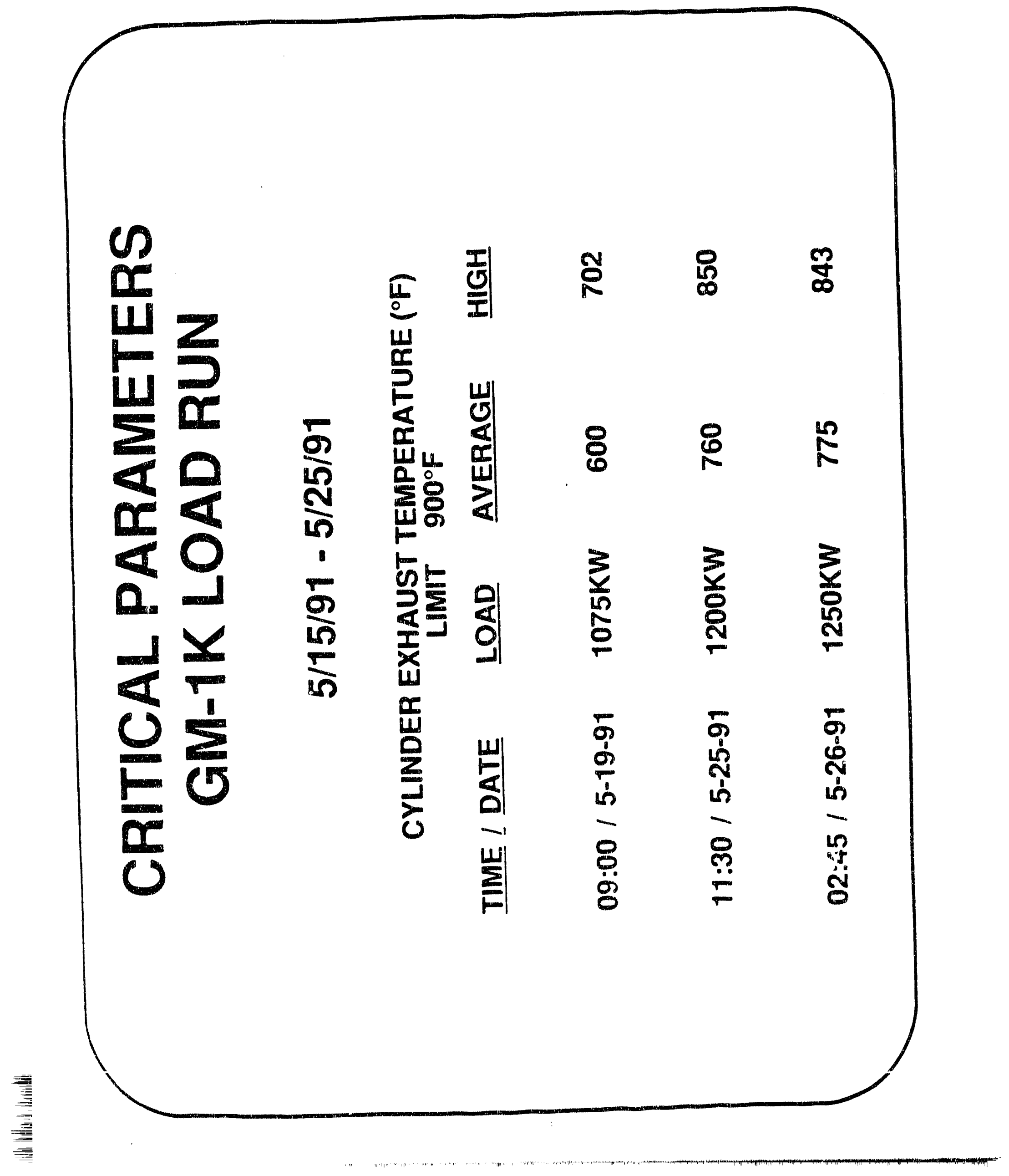


$\infty$

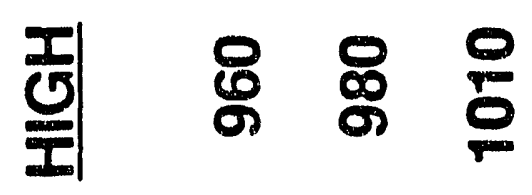

口

U 2

$\underline{\mathbf{r}}-\frac{\widehat{D}}{\mathrm{o}}$

$\sum 0 \frac{5}{10}$

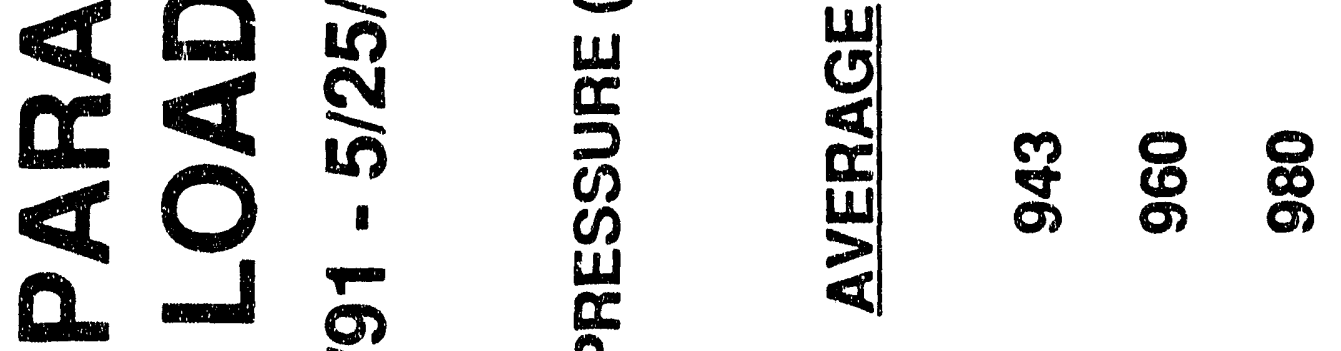

$11 \frac{2}{4}$

$<5 \frac{5}{10}$

$E \sum_{0}^{1}$

or

0

$\frac{\pi}{2}$

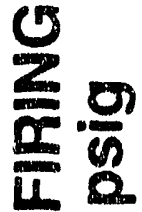

땡ํㅇ

喼

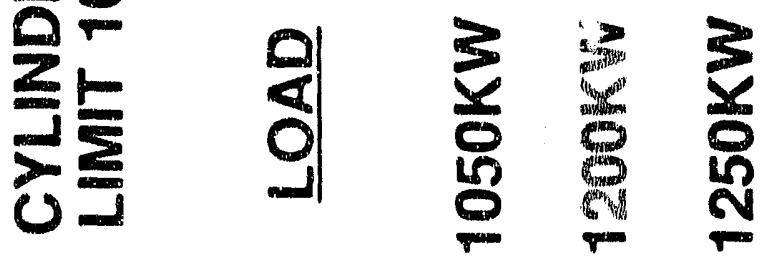

$\bullet$ 
$\omega$

히 웅 品品

of

U1

$\operatorname{lac}^{2}$

4
0
0
0
0
0

$\mathrm{De}$

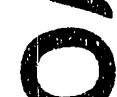

DL

14

$\Leftrightarrow$

(3)

$\rightarrow=$

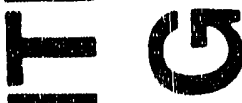

$\mathrm{DC}$

C

$\frac{2}{6}$

U

ab 8

D. $\frac{1}{n}$

$\sum 0$

0 ใ

or

4 is

Q

5

$\begin{array}{lll}\text { \& } & 0 & 0 \\ 10 & 18\end{array}$

4
5
4
2
2

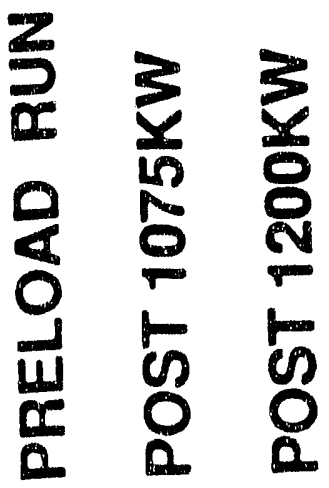

吾 
$\omega$

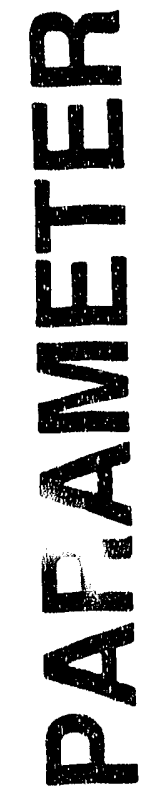

$u$
0
0
8
4
$\frac{1}{0}$
0

2
$\frac{1}{2}$
0
0
5

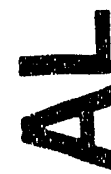

O

E

r

0

1

U1 $\frac{9}{2} \frac{9}{9} \frac{0}{9}$

\& $N$

눙 $\frac{1}{0} \quad \frac{1}{\circ}$

N in in

ㄴ.

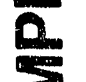

II

5

$\Gamma T$
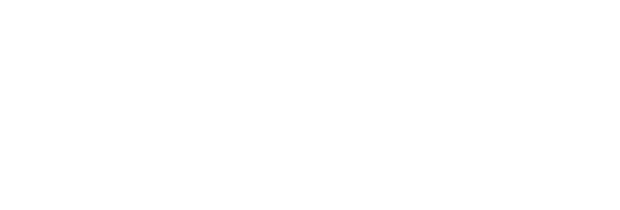

c

4

2

5

1. 0

$\circ$

N

-

$\frac{1}{4}$

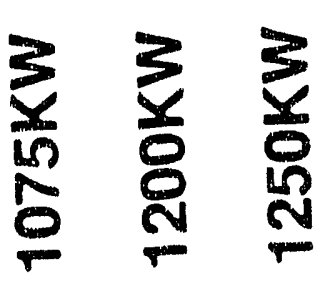

$\frac{3}{2}$

$\infty$

11

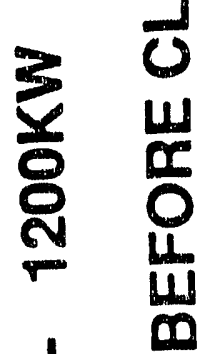

$\star$

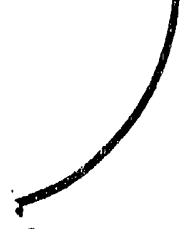




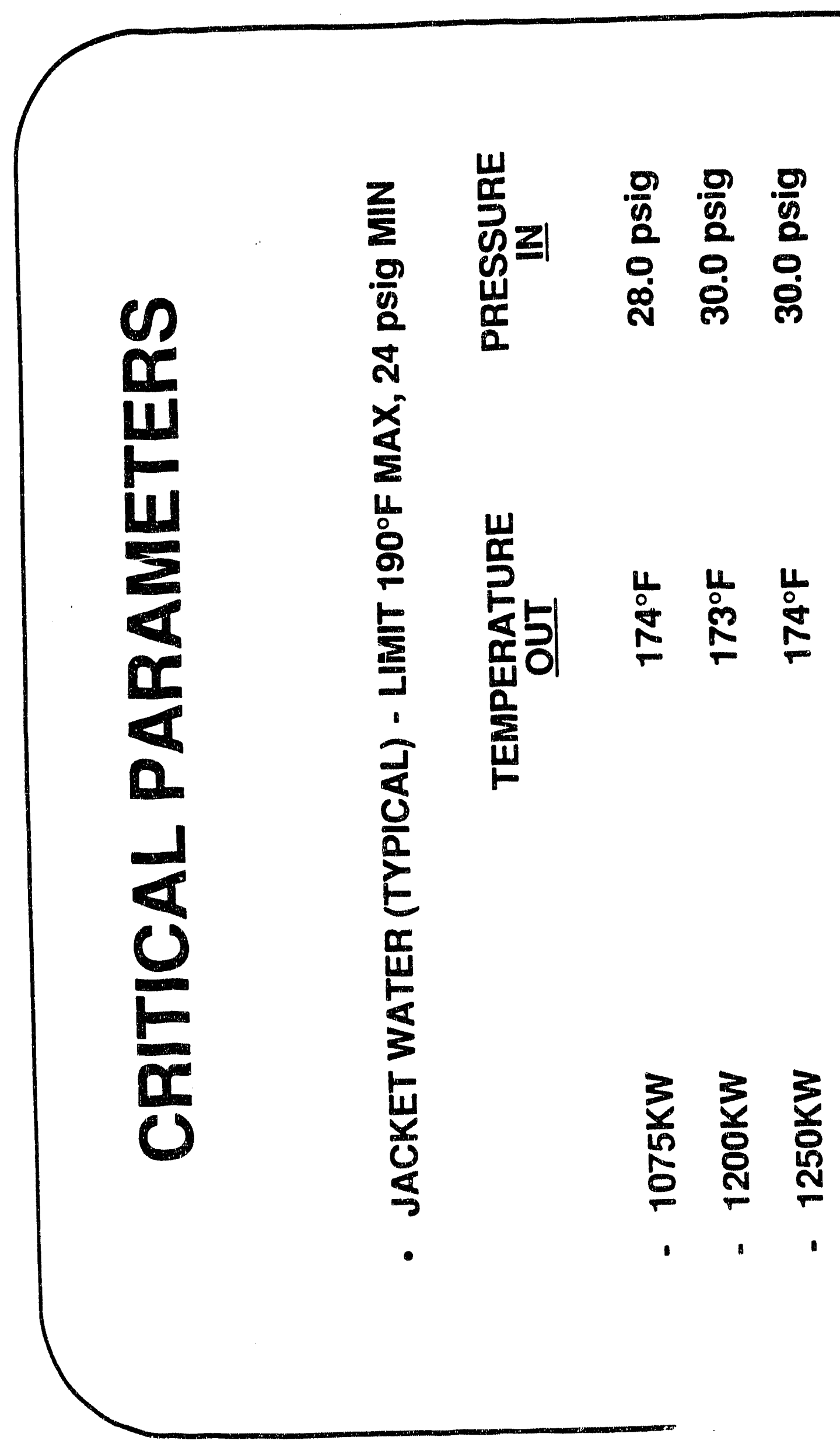



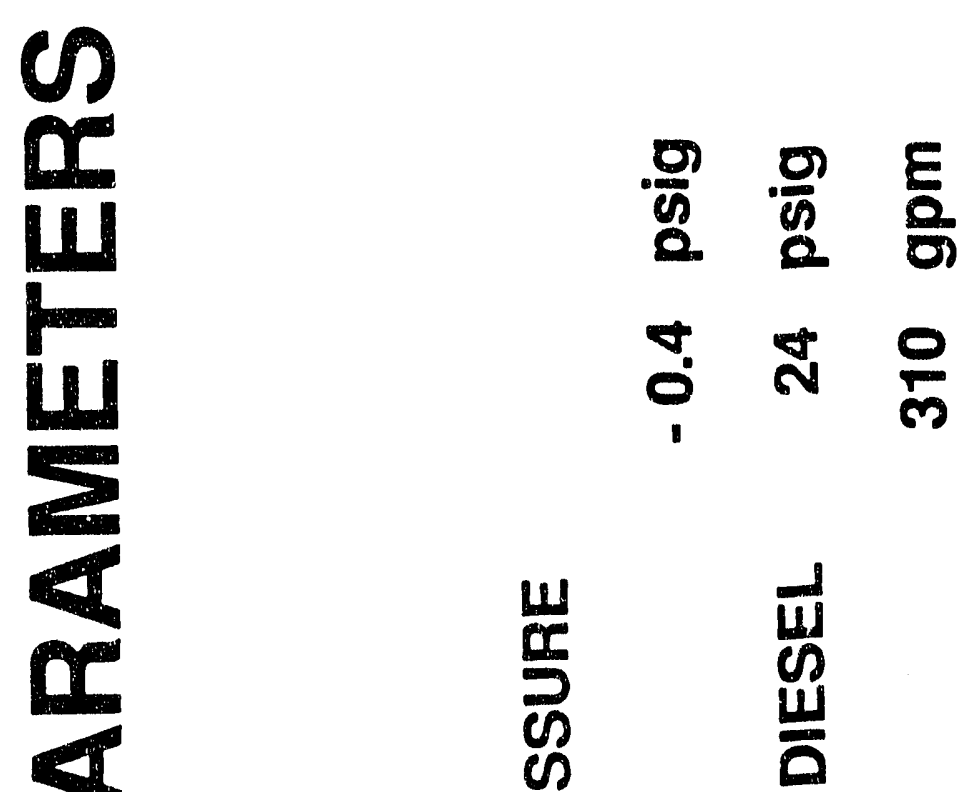

a

4

m

rat

宸

2. WU

는 $5 \frac{2}{5}$

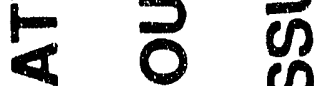

$\geq \geqslant$ 崖

ㄷ․․

0

a

c)

- 


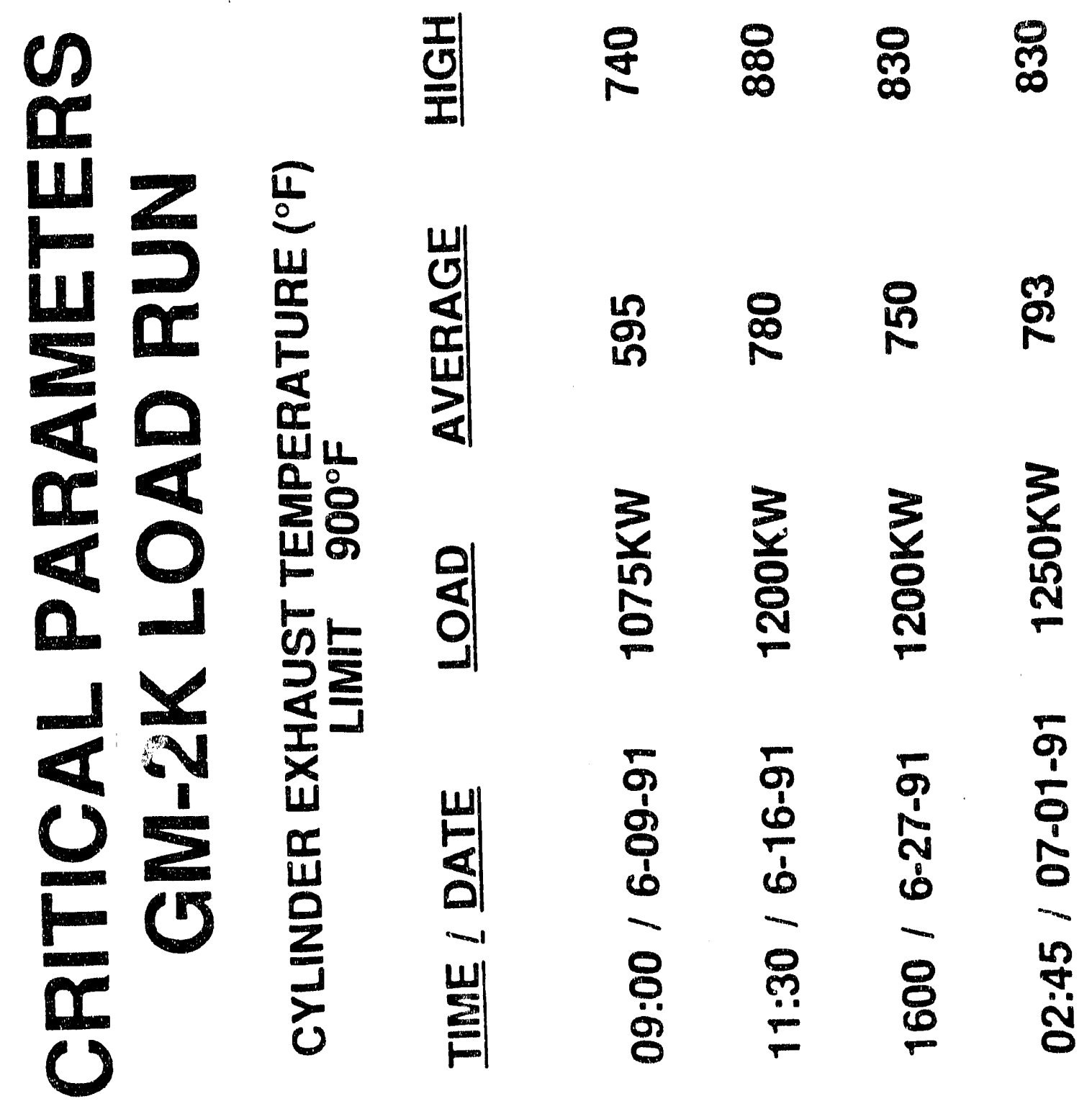




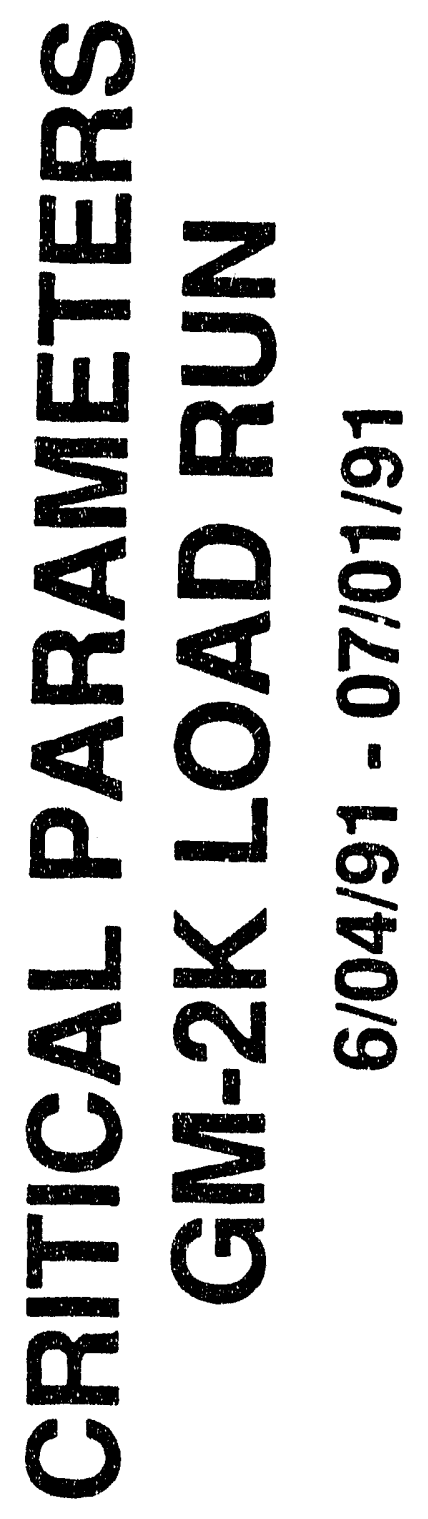

뮟 \&

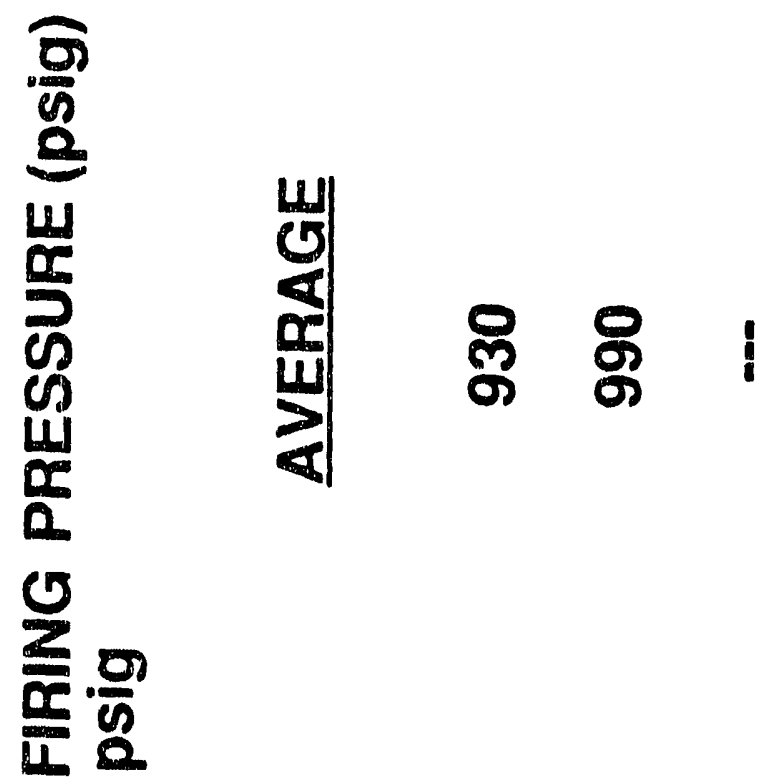

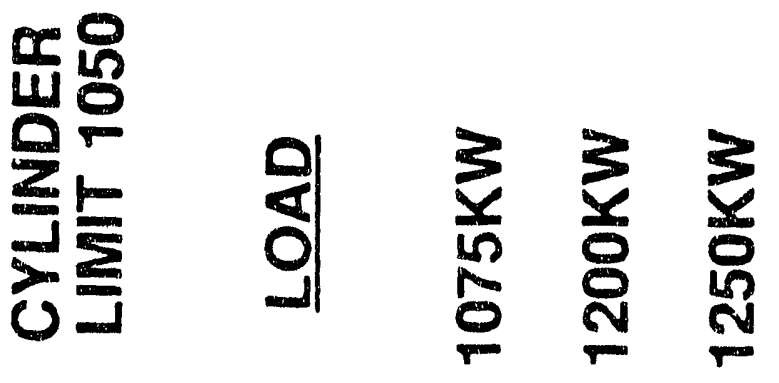


$\omega$

이 온 앙 윰

ณ

山

2

㟧

w

骂

क

20

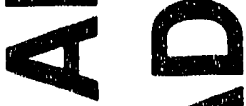

or 4

崖

a

$\leftarrow 0$

a

$1 \frac{1}{2}$

a

0

닌

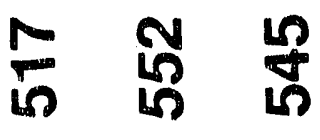

II

또 음

20

0 용

웅

แบ

อ 10

Z

$2 \pm$

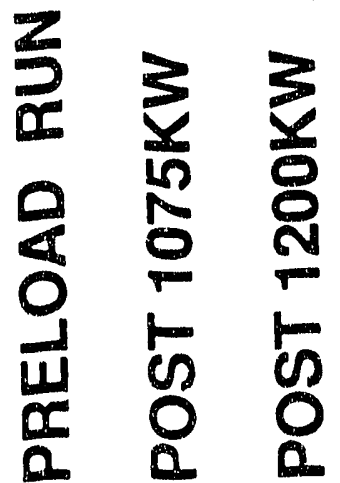

- 


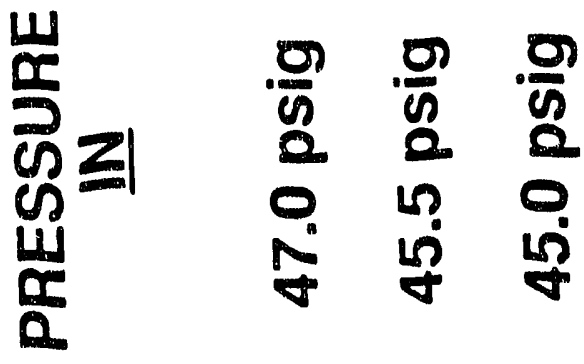

$\omega$

$\propto$

U

5

$\underline{r}$

政

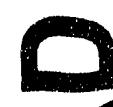

or 1

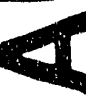

口

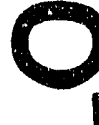

1
0
0

$\frac{x}{2} \frac{w}{5}$

능 $\frac{5}{\circ}$

\begin{tabular}{lll}
4 & 1 & 1 \\
$\circ$ & 0 \\
0 & 0 & 0 \\
\hdashline & 0
\end{tabular}

or

난

ก

E

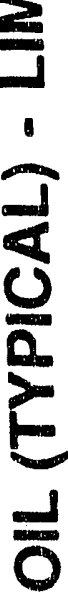

ш

ఏ

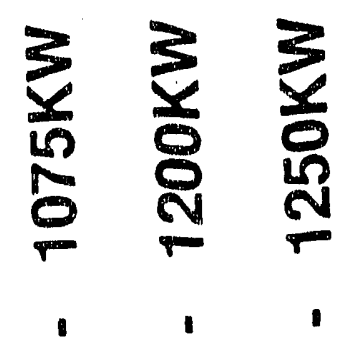




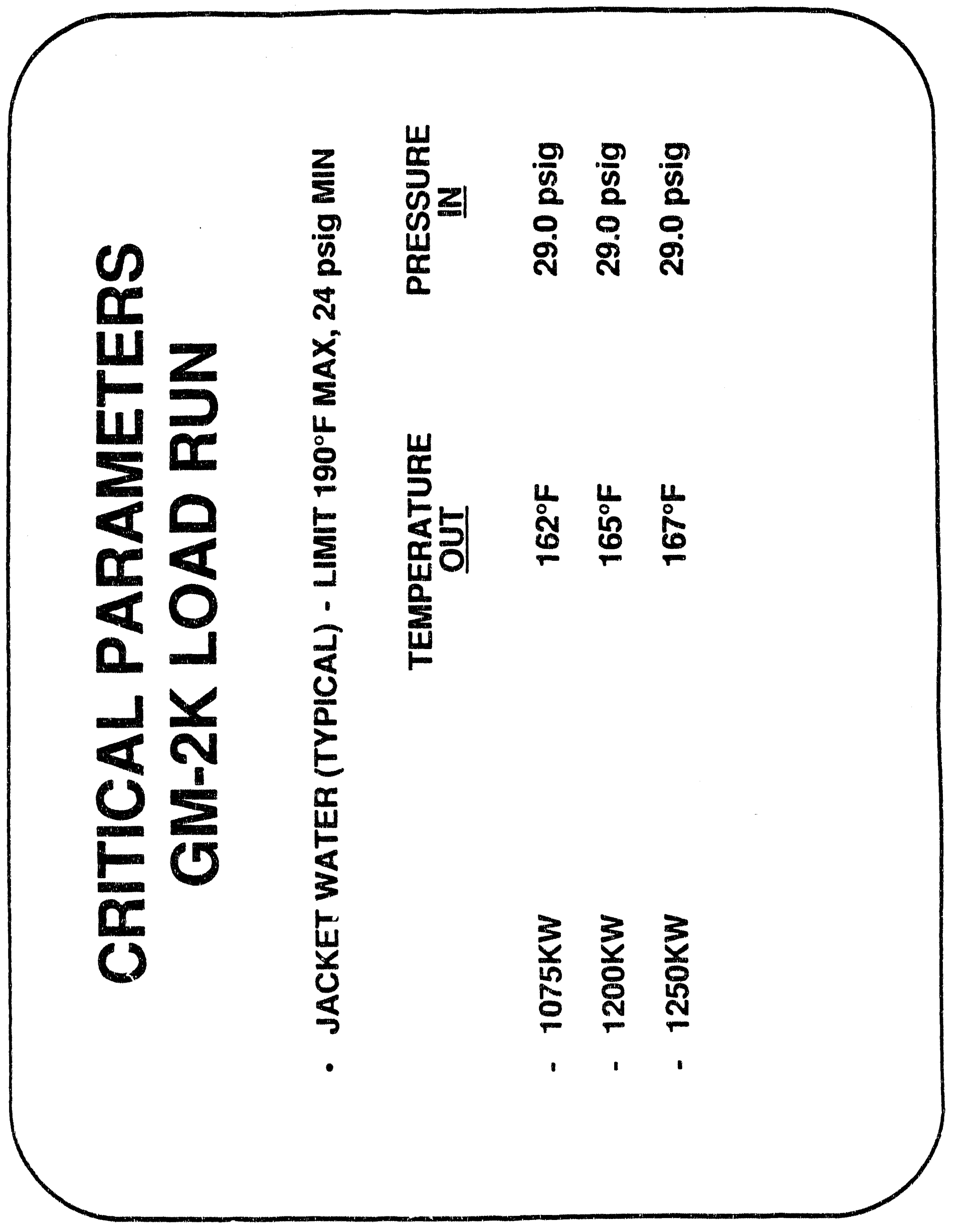




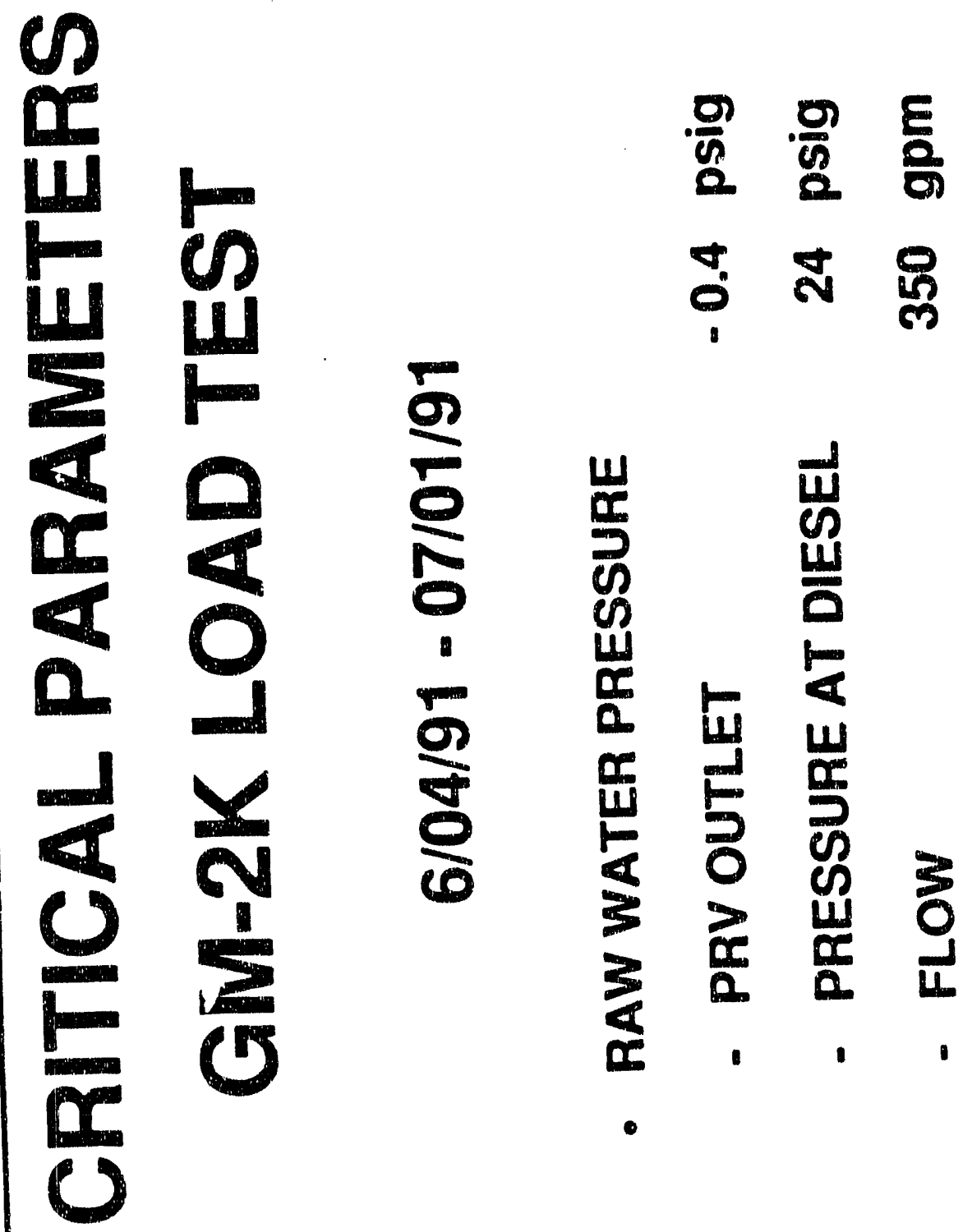


ENGTNEERING EYALUATION OF TAE GENGBAT MOTORS (GM DIFSEI BATING AND CAPABIIITIES (UI)

APPENDIX I

MODEL 16-278A ENGINE PRESSURE DROP THROUGH

EXHAUST PIPING 
Tooded 16-278A Engine

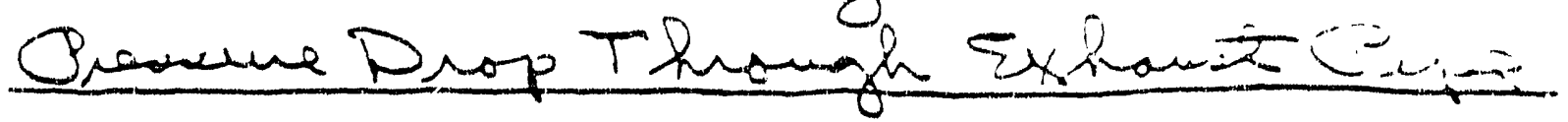

Westinghouse Savanuah Reive Compramg Ineine.

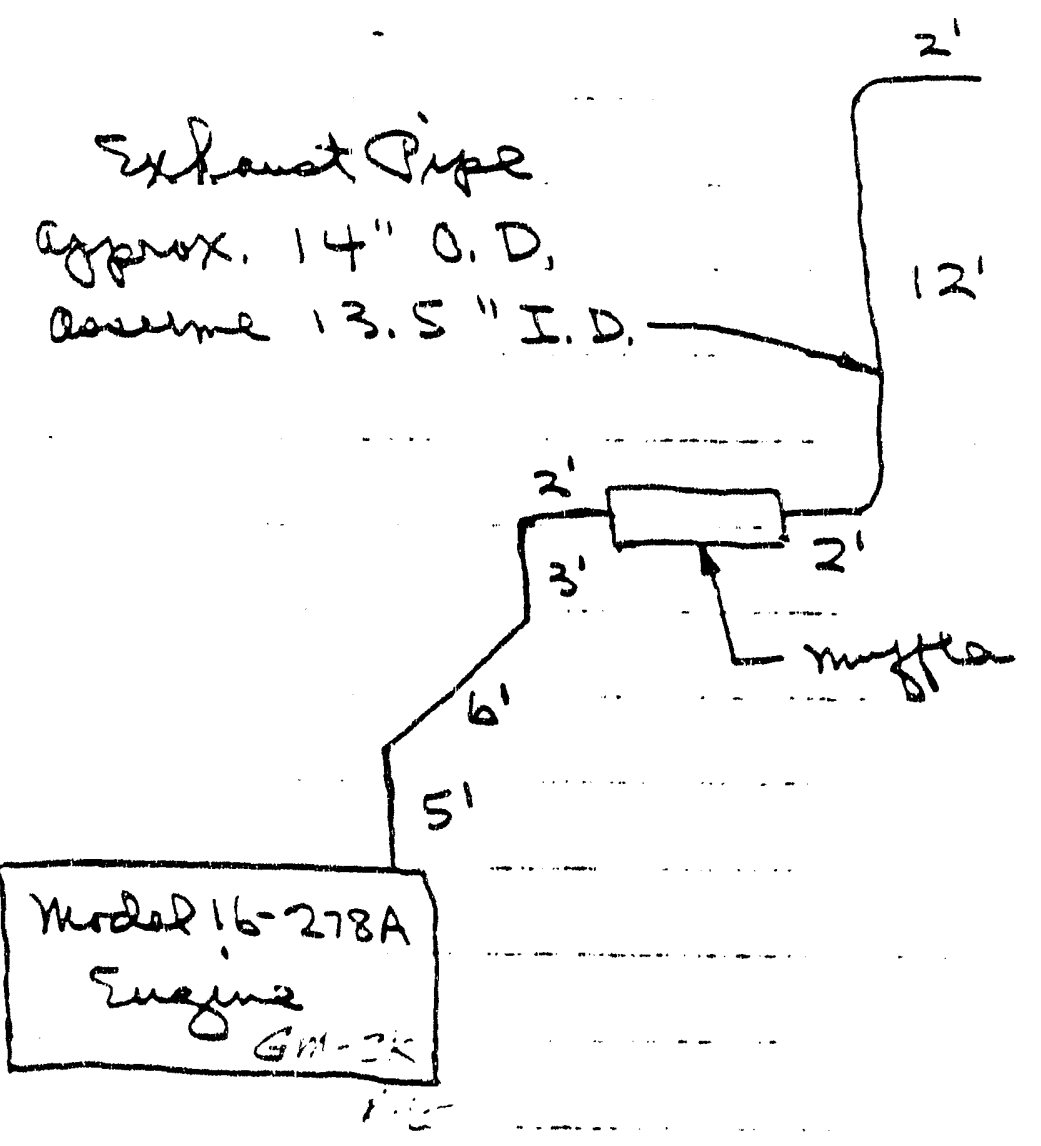

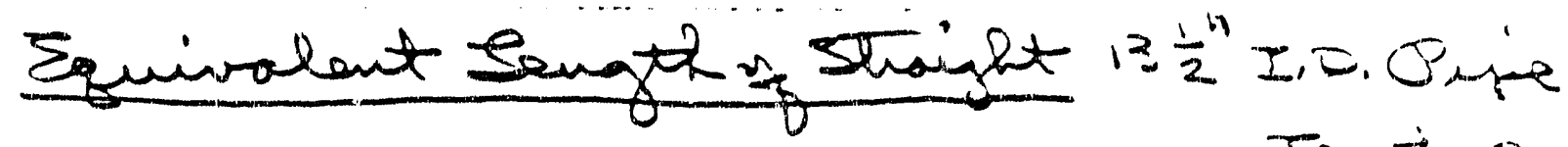

Stinight Oipe

$3-90^{\circ}$ exbaure

$2-20^{\circ}$ 'Bender
$3 \times 30^{\prime}$

$2 \times 8$

Jamgin of strighosing$$
32,5
$$

90

16

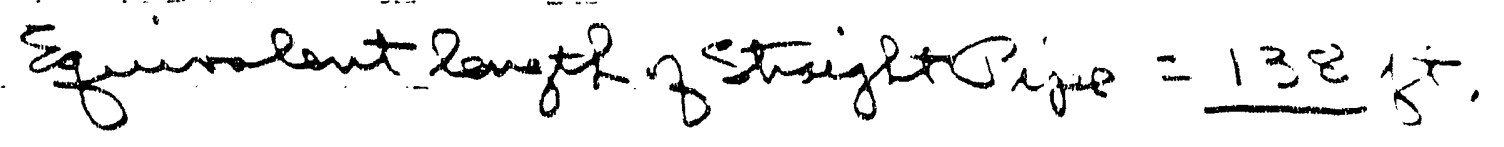


$=$

Volume of Extramit hiox

Bowar Nolume is 30 To $33 \%$ move timan sugine diafescement volumis une $30 \%$

$$
V_{\text {ol. }} \text { ain }=\frac{\frac{\pi}{4}(8.75)^{2} \times 10.5 \times 16 \times 1.30 \times 7=0}{1728}=\frac{5+72}{C F M}
$$

of an jengine

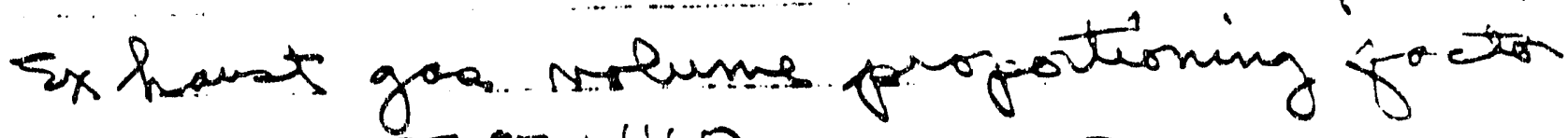

$$
\frac{750^{\circ} F+460}{70^{\circ} F+460}=2.283
$$

Exhanst lop Volume $=5472 \times 2.283=12493 \mathrm{CFM}$

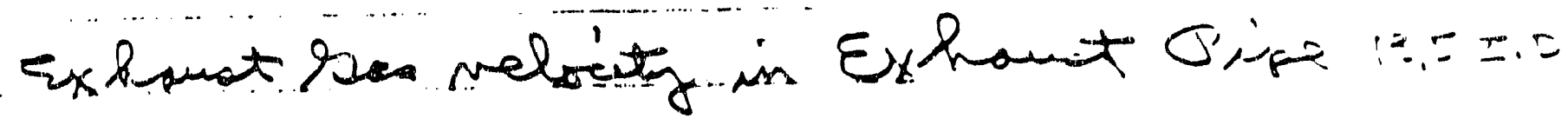

$$
\text { Vel }=\frac{12493 \times 1728}{\frac{\pi}{4}(13.5)^{2} \times 12 \times 60}=209.5 \mathrm{kt} / \mathrm{sec}
$$

This in 143 milea lows

Colculating the preseune lose in did 122 tr of etrougt gire.

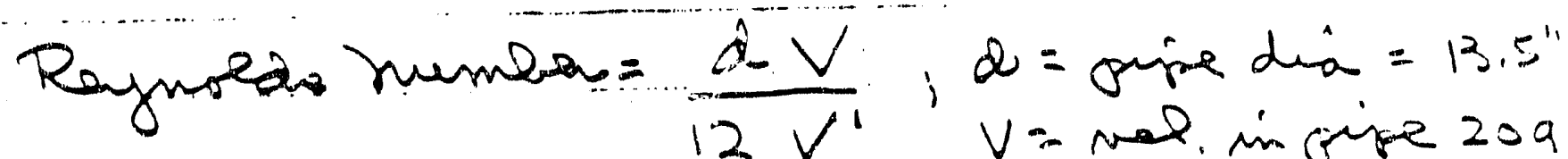

$V=$ Nel. in ginge 209. El

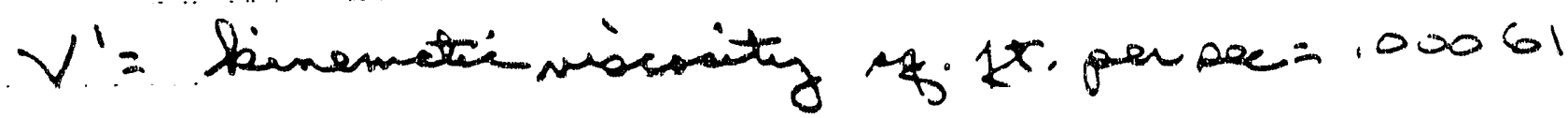




$$
\text { Ragnode Rumber }=\frac{13.5 \times 209.5}{12 \times .00061}=386370
$$

The presence lope therigh exhanct giging using Daing equarion

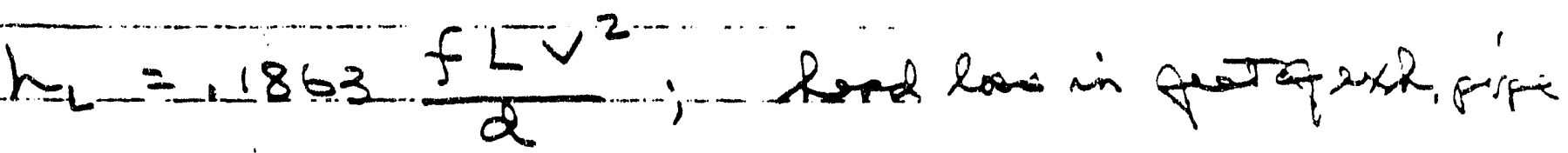
$f=$ fuctain fots from Regured cunes=.025

$L=$ langt y jipe -138 ft.

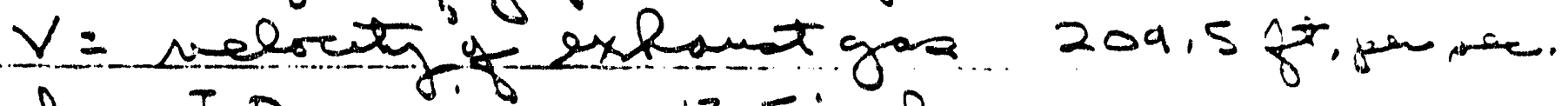

$d=I . D$ of pipe $=13.5$ inches

$$
h=\frac{1863 \times .025 \times 138 \times(209.5)^{2}}{13.5}=\begin{aligned}
& 2089.6 \text { से } \\
& \text { 2xhoutgos }
\end{aligned}
$$

appors isiste weight of exhanct goo.

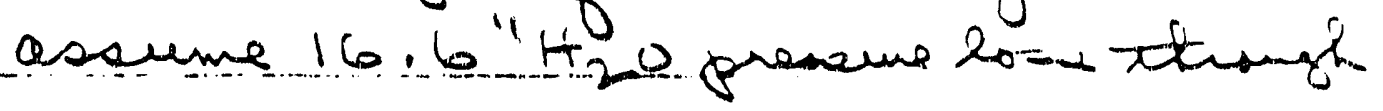
dpiping sot . $12^{\prime \prime} H_{20}=.433$ PSI. oo $16.6 " \mathrm{H}_{2} \mathrm{O}=1539 \mathrm{PSC}$

$$
\begin{aligned}
& P V=W R T ; \quad R=51 \text { assumd } \\
& w=\frac{144(14.7+.599) \times 1}{51(750+460)}=.0357 \text { poumd / an. jt } \\
& \text { weight of estant (ext) }
\end{aligned}
$$

- Hed 200 $=\frac{2089.6 \times 10357}{144}=.518 \mathrm{PSI}$

or $518 \times 2.308 \times 12=14.3$ inche of wota preosur hos through exh. giging. 


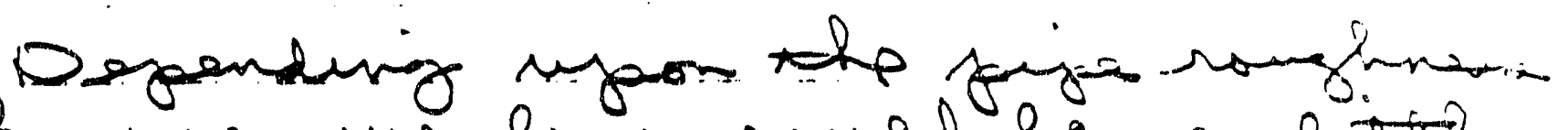
the slessue los coned be a lite - Righer.

hsing an experime fotor the grionemp loos tusugh the giging comas aut to about 38 inche of wata for 300 iti on $38 \times \frac{138}{300}=17.5$ incher is wath rewiuk durp though exh-antgiping.

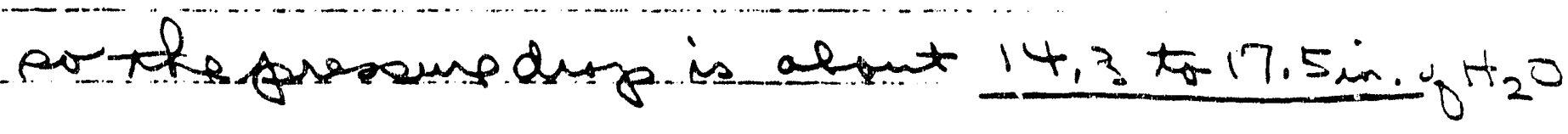
The total gressue lope is $32 \mathrm{in}$. of witite so the loos though the mugfen and opponk arrecter is about $17.7 \mathrm{tar} 14.5^{\prime \prime} \mathrm{H}_{2} \mathrm{O}$

The dosised presume brese is $1.5^{\prime} \mathrm{Hco}_{\mathrm{g}}$ o 20.4 in $\mathrm{H}_{2} \mathrm{O}$

The sccommended pipe sing for $x$ hi: engine st The 1200 Kw Noteng in durnt 18"I,D. pe Corper Bosemer.

Qulations settriy up a ribatong figuency in exhoust syatem. 
5

The lenif of The oyptem to otidy so for t te engine to inutiter becanse a presoure wave cond be ent brak fom de mutiten.

- The selovity oound in the exhourt ga

$$
V=49 \sqrt{T} ; 49 \sqrt{750+460}=170+\frac{1}{t}, 1000
$$

The wave fequency $=\frac{8 c y e \times 720}{60}=96 \mathrm{~V} / \mathrm{c}$.

becone 2 on findor fine qute che togethe

and $v=6 \lambda$ a Shen $\lambda=\frac{1704}{96}=-17.75$ fect for a fues

sume the wave tornem

to the murper and bounci-

bock th gript length that.

is cuticis $=\frac{17.75}{2}=8.875$ 这.

1725 ft for a quev wari.

The langt of thingt ofpe lefole mufte is obout 16 ft VS $17.75 f^{t}$ there pa growinitg fo a plight chopingroph exhant.

Qow $x=30$ math

rune 25,1991 


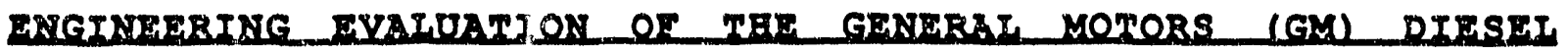
BATING AND CAPABIIITIES (VI)

ARPENDIX M

COMPRESSION PRESSURE ANALYSIS 
ENGIN

SYSTEM

ALRYYSTS
ENGINEERED APPLCATIOUS, CORPORATION

ENGINEERING AND DESIGN CONSULTANTS 476 Sarsiold Drive, Rochosior Mills, Michigan 48307

Phone: 313 - 853-3000
ENGINE

DESIGN

SPECIALISTS

may 24,1991

Mu. Robert E. Mhos P.E.

Westinghouse Sarawak River Company P.O. Box 616

aiken, SC 29802

Subtext: Model 16-278 A Engine Engine Performance

Pea Bob:

I have reviewed the engine

performance data that you gave me by phone today. The engine exhaust temperature the aylinda firing pressures and the compression pressure are all within the performance parameter limits. The compression pressure are recisonable for so lite engine operation and to will get beater as the engines piston singe become seated. It takes about 300 ta 500 hours of engine operation, under load, to seat the ring e and sometimes even a little longer with cham plated. cylinder liners. Seating these enguriea singh. is gist like seating the ring of your can eng un. which sometimes tabes a month. 
2.

Seating the singe depends upon the cylinder liner material and its surface finish, the piston singe, and their. mataiol and the lubricating ail used. in the engine. Alow when taking cylinder compression reading the cylinder tends to cool off which lour en The compression pressure?

If you or any of the other people would like to discuss this or other problem e in greater detail please feal free to call me at 313-853-3992 Sincerely. Band Soungley 
May 24, 1991

Mr. Robert Gross

Westinghouse Savannah River Co.

Savannah River Site

Alken, South Carolina 29801

Via Telecopy: 8035579601

Ref: Cleveland Diesel Analysis, FaAA Project Mo. FL.75192

Dear Mr. Gross:

This afternoon by telephone you have reported to me some of the results of the ongoing requalification testing of the 108-K1 Cleveland Diesel emergency generator set. of interest is the observation that compression pressures of some of the cylinders appear to be below the specffication of 550 psig following testing at $1200 \mathrm{~kW}$. You reported that these values are on the order of 20 to 30 psig lower than those measured prior to $1200 \mathrm{~kW}$ testing.

Other performance and condition parameters were reportedly in it ne with specifications and expectations. For example, the peak firing pressures are in the high 900 psig range, and the exhaust gas temperatures are weil behaved and not changing. Spectroscopic analysis of the lubricating oil shows no detectable tin, and a copper level trending up, and then stabllizing. Except for a raw water temperature problem that has been diagnosed and addressed, which did result in a correlated reduction in lubricating oil pressure, the pressures and temperatures were within specifications and expectations.

You requested my comnents and thoughts on the compression pressure readings. I understand that these readings are made with a Keane gage with a 2000 psi analog dial readout. I am familiar with this particular instrument, and for critical measurements of transient cylinder pressures. I have used piezoelectric transducers and digftal readout and recording of data. The Keane gage itself has an inherent repeatabllity of perhaps \pm 20 psl, and like all analog gages, suffers in comparison to digitaī instrumentation for precise

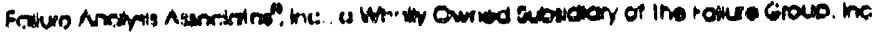


measurements of small differences in arge numbers.

The true value of compression pressure in diesel engine cylinders is aiso not a constant, but has a random component, analogous to cycle-to cycle variations in firing pressures. The details of the position of the rings in their grooves, the exhaust valves on theip seats, the distribution of lube oil on the rings, vaives, piston lands and piston skirt will all influence the true compression pressure. The compression pressure will also vary with operational time. As the rings begin to seat, the pressures should go up, if all else is equel. As the rings continue to wear, the end gaps will ellarge, and the compression pressures would then tend to decrease somewhat.

You did inform me that pision position measurements were taken prior to the initiation of testing, so if bushing condition becomes an issue, subsequent measurements will indicate immediately if any wear has occurred. You have aiso not observed any correlations between cylinders with low compression pressures, and differences in firing pressure or exhaust temperatures. I would recommend that you perform formal regression analysis to see if there are any correlations. If your varlations in compression pressure are random, I would expect low correiation coeffictents to exist.

To further detemine if the compression prossures are anything. other than randomily distributed, I would recommend gathering additional data after further operation of the engine, including the planned operation at $1250 \mathrm{~kW}$. All the information that you have provided to me, and the information you provided to me in answers to my questions. suggests that the engine is capable of continuing the test program without incident.

If you have any further questions, please call me.

Very truly yours,

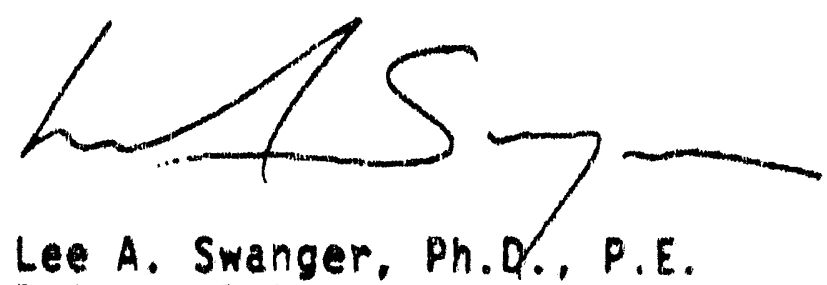

Principal Englneer

Director, Miami Office 

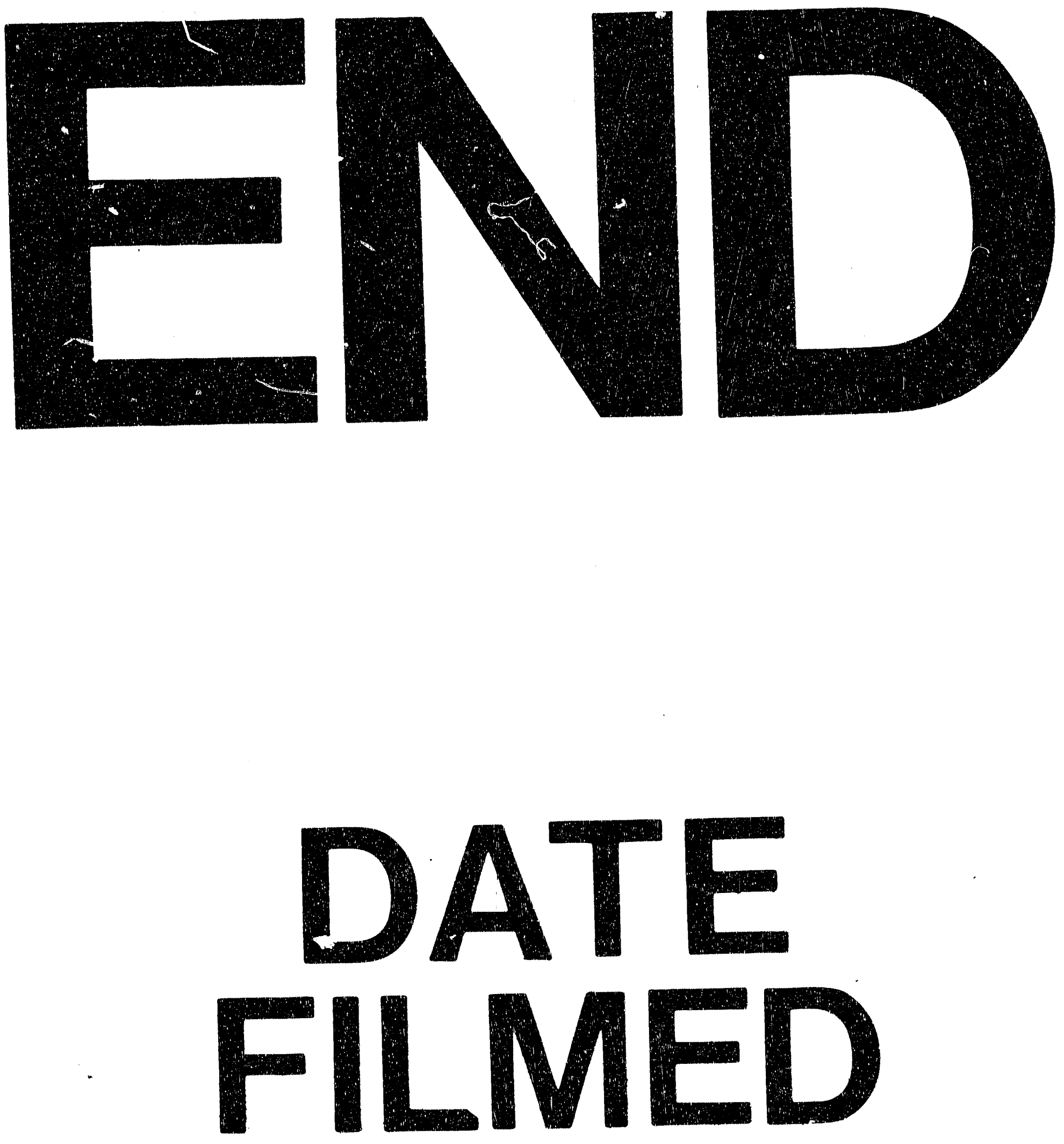

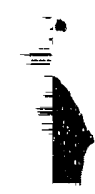

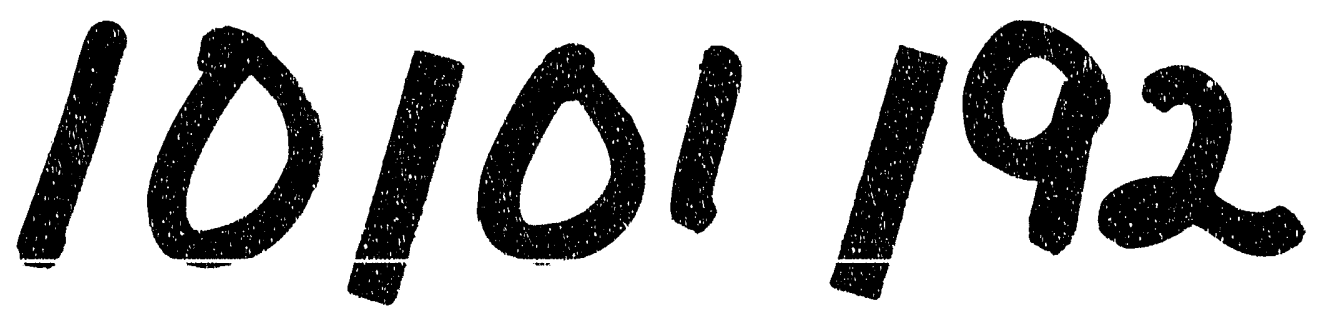




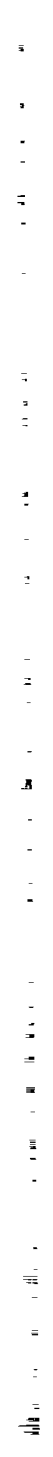

